







\section{POLITICAL LEADERS OF \\ PROVINCIAL PENNSYLVANIA}




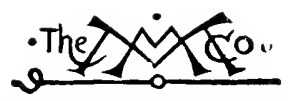

THE MACMILLAN COMPANY

NHW YORK - BOSTON - CHICAGO - DALLAS ATLANTA - SAN FRANCISCO

MACMILLAN \& CO., LiMITED

LONDON - BOMBAY - CALCUTTA

MELBOURNE

'THE MACMILlaN CO. OF CANADA, Lte TORONTO 


\section{POLITICAL LEADERS}

OF

\section{PROVINCIAL PENNSYLVANIA}

BY

ISAAC SHARPLESS

President of Haverford College, 1887-1917

New 照ark

THE MACMILLAN COMPANY

1919

All rights roserved 
Copraigut, 1919,

BY THE MACMILLAN COMPANY

Printed from type. Published April, rgy.

Nortwood Tress

J. S. Cushing Co. - Berwick \& Bnith Co.

Norwood, Mass., U.S.A. 
I. C. 



\section{PREFACE}

THE names of the Quaker politicians in this book have been selected with the view of showing the applicability (or otherwise) to the practical affairs of government of the principles which to some extent ruled their lives.

That they were all, from William Penn down, more or less of idealists, is a fact of which they themselves were very conscious. As all idealistic attempts have their lessons either of adoption or avoidance, this one may be worth recording.

As a whole the experiment succeeded. As in politics in general there was temporizing. Their anti-martial views were the most difficult to apply consistently and finally were the cause of their abstention from public affairs; but there are interesting deductions to be drawn both from the threescore years of success and the ultimate break-down. Their ideas of civil and religious liberty, their treatment of the Indians, their penal and hospital systems, the large material growth which accompanied their management, and the general tone of their public life afford a basis of a favorable judgment upon their experiment.

The religious leaders of Friends have received ample recognition in print. Something, however, is still due to these practical men who wrought with such devotion in working out the principles of the "Holy Experiment."

Haverford, Pa.

1919. 



\section{CONTENTS}

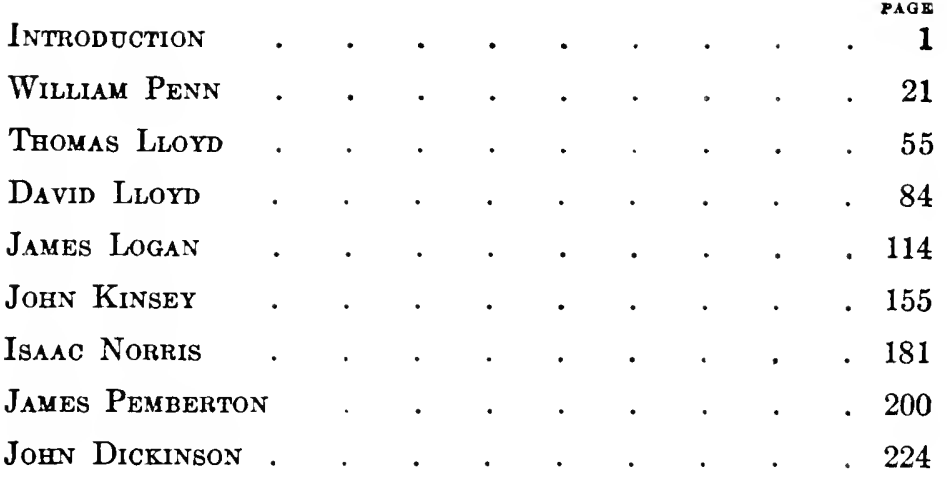





\section{PENNSBURY SERIES OF MODERN QUAKER BOOKS}

The Book Committee of Philadelphia Yearly Meeting of the Society of Friends proposes to issue a series of books in uniform binding under the above title. These have been written during the past twenty-five years in England and America, and in a general way express the views of the Committee on the history, present position and outlook of the Society. Doubtless some passages may not satisfy the judgment of individual Friends or perhaps of the Committee as a whole, but without making unreasonable limitations such variations are unavoidable.

Some or all of the following books may be included in the series:

George Fox, An Autobiography, Rufus M. Jones. Man's Relation to God, John Wilhelm Rowntree. The Rise of the Quakers, 'T. Edmund Harvey. Quaker Strongholds, Caroline Stephen. The Story of Quakerism, Elizabeth B. Emmott. William Penn, John William Grahan.

A Quaker Experiment in Government, Isaac Sharpless. John Woolman, Amelia Mott Gummere.

History of the Society of Friends in America, Allen C. Thomas.

A Dynamic Faith, Rufus M. Jones.

Political Leaders of Provincial Pennsylvania, Isaac Sharpless.
Editor of the Pennsbury Series
IsAaC Sharpless
Third MontiI, Haverford, $\mathrm{P}_{\mathrm{A}}$. 1919. 



\section{POLITICAL LEADERS OF PROVINCIAL PENNSYLVANIA}

\section{INTRODUCTION}

A ROUGH classification might divide ethical standards into two groups. One is based on results, the other on principles. The first is the favorite method of the politician, the man on the street and on the farm. If a thing produces good, it is good in itself; if evil, evil. A method of action, a piece of legislation is to be justified or condemned by the consequences which follow it. In ordinary affairs not involving moral considerations this sort of judgment is universal. Business decisions are wise or unwise according as they prosper. Fiscal legislation is ordinarily decided, not by eternal principles of political science, but by results as shown by history and experience which followed similar legislation in the past and are likely to follow it in the future. Perhaps ninety-nine per cent. of the acts of legislatures are determined by such considerations.

Philosophers codify these methods and variously call themselves hedonists, utilitarians, pragmatists and so on, as they vary the theories to suit the conditions of the age or country.

If one could see all the results nothing could be better. But the wisest of philosophers can only see a little way ahead and the shrewdest of politicians and business men have a limited horizon. What is manifestly useful to a 
few people immediately affected may not be for a more distant future or a wider eircle. The primary results may seem highly beneficial but those which result from these, unseen by the performers, maty be disastrous.

The other sort of standard is based on something supposedly more fundamental. Areording to this when it comes to decisions involving the moral idea there is no room for a consideration of consequences. Things are inherently right or wrong. One must be gruided by what is called the moral law. If we can ascertain this as applied to the case human duty is determined. It may lead apparently into all sorts of pitfalls and failures but in the long run it will prove a safe guide. In the eternal plans of a Divine Ruler of the universe that which seems inexpedient to us ma be of the highest expediency; our very failures may be the means to the greatest success. The real good is the permanent, abiding, satisfactory result which comes by the operation of all the many factors and forees producing it, too various and too hidden for human ascertainment, but which are all parts of one great plan. It is the duty of the individual not to mar this plan. If he knows what his part is, small or great, resulting to himself as it will in loss or gain, resulting to others apparently for material good or ill, he performs it faithfully, and concerns not himself greatly with what follows. His conscience or judgment determines his course and that is all there is to it.

But how is the man who takes this attitude to find what this moral law is? How is his conseience or judgment to be enlightened? There are quite as many philosophic views on this question as in the field of utility. Men base the standards of rectitude on reason, on intuition, or revelation, or on authority human or divine, and deduce a code of conduct which satisfies the argument. Sometimes it is expressed in the sacred books of their religion, sometimes it 
comes to them directly as the expressed will of their Deity felt in their consciences, sometimes as the logical result of their rational processes.

The standard Friends of the past have belonged to this second class. When their duty was made known to them they were not disturbed by results. So they went to jail or to death for a conviction which often secmed trivial or foolish to others, rather than abate an item of it. If one argued with them that their liberty might do more for their cause than the small testimony, the argument fell on deaf ears. That testimony was their present duty and all the rewards of disobedience, all the plausible considerations of results, had no bearing on the case. One and all the Friends of the first generations and the typical Friends which followed them were never utilitarian.

But the interesting fact remains that though they thus ignored results they got them. Their policy or, as it often seemed, lack of policy, secured consequences. They received religious liberty earlier and more fully than the temporizing sects. They had their marriage regulations made legal; they were allowed to affirm rather than to swear; much respect was paid to their anti-martial views; they effected reforms in the jails and asylums of England and America, and their treatment of aborigines and its consequences has become historic.

There are many reasons for saying that fidelity to right in the face of seeming disaster works better than any one expects. There are many facts of history which show that men and nations do get along, when they follow the right, in a way which no one could have foreseen. There is some inherent vitality in the truth which makes its own way, or has a way made for it.

The Friends have abstained often in the past, from the activities of polities and of government. Their thoughts 
have been so pervaded with the idea that immoral acts cannot be made moral by the beneficent consequences which seem likely to result, that they become inefficient in the work of practical politics as it sometimes exists. When they swallow their seruples they cease to be in harmony with the Friends' position and lose their standing in the church. Hence we have frequently found that those members who have become active in political life have been on the fringe of the Meeting rather than, as they were in early Pennsylvania, the trusted ministers and officials, whose state duties bore on their consciences no less rigorously than their ecclesiastical duties, but who would sacrifice either rather than violate an apprehended moral obligation.

Good seems to come from the chicanery of politics no less certainly than from war. Out of the selfishness, the venality, the immoral strategy of the presidential conventions has come the greatest line of rulers any country has ever seen in any age. Fron the days when Hamilton traded off with Jefferson the location of the capital city for the funding of the state bonds, in the first Congress down to the days of the last Congress, many measures yielding valuable results have come as the results of bargains not always honorable or moral. Every legislator knows that in order to have a good measure passed it often seems necessary to support others who want bad measures passed, and the perfectly independent man who yields nothing in this way is hardly efficacious in the councils or acceptable to his constituents. To do evil that selfish projects may succeed and to do evil that good may come are the lines that have too frequently distinguished the evil from the good legislator.

The principles which have been the keynote of Quaker morality and those which define the average morality of the politician even of the better sort are widely apart. The 
one is idealistic, the other utilitarian. The one has never been able to convert the other to the theory that idealism in the long run is of the highest utility, and the other has had no faith in any principle whose utility he cannot grasp as likely to ripen in the very near future.

To this extent we can sympathize with the abstention of Friends from politics. If a state is dominated by an unholy machine which allows no one in office except obedient henchmen, who must be without scruple or independent character, then "the post of honor is the private station." There may be a place for them in the ranks of the militant reformers, but hardly in official life.

Through all the years covered by this volume there was growing up, basing itself on George Fox's advice to keep clear of the "Commotions" involved in government, a feeling that Friends should take no part in public life. Their course in the Revolution, which had involved the disownment of some 400 members for participation in the warlike affairs of the day, mainly on the American side, made them unpopular. They withdrew into a more mystical life and an uncompromising devotion to principle and testimony, and the Quaker of the nineteenth century was evolved.

This would seem to indicate that the application of a Quaker conscience to state affairs in a non-Quaker community is impossible.

Probably conditions will never be better than in Colonial Pennsylvania, and there it broke down, after 70 years' trial, though at first against the popular will, in the face of apparent political necessity.

But it does not prove that Friends may not accept many posts in government, both executive and legislative, which need not touch on their convictions and in which they may render signal service.

They may also bring the attention of a nation to the 
moral issues of the day, a task for which Friends with the ancient sort of standards would seem to have great advantages.

It tones up the nation to have its thoughts turned to ethical, rather than exclusively economic subjects. One moral question brings another in its train and men get to thinking in terms of right and wrong rather thin expedient and opportune. In the decade prior to our Civil War when men were fused together on the subject of the rights of man, and used such phrases as " the higher law," "the irrepressible conflict," "the true grandeur of nations," there was a manifest raising of standards. Then came the war and the host of questions of currency, tariff, revenue, and material issues generally, which divided parties in the succeeding years, and morality took the second place to economics and men thought in dollars rather than in righteousness. We had a great growth in wealth and all its unhealthy accompaniments of monopolies, corporate interference with government and boss and machine rule in politics. Later the moral sense of the nation reasserted itself and the development of attention to human rights and the social conscience, and to specific matters like temperance and peace and civil service reform, went on apace. It is one of the great evils of war that it draws the interests of men from such movements, to the more pressing but less vital ones of national defense, sources of national income, reduction of national expenditure for social development, and all the lesser breed which designing politicians take advantage of to press their own selfish designs for office and emolument. Some beneficent reforms which need advertising to make people appreciate them are thrust aside by the insistence on the more spectacular national needs, and the wholesome discussion of moral and political reform in a democracy is impeded. For this discussion under normal conditions is 
the very lifeblood of progress. The American nation will not get far astray if its attention can be seriously turned to a great issue and a great need. How quickly when it once grasped the dangers of corporation control of politics, with many blundering and foolish steps, it is true, it improved the situation. Free discussion and the honest purposes of an intelligent electorate can be depended on to clear away any heresy before it reaches the stage of serious danger to the national soul.

But morality must have the right of way, and while matters in which the economic rather than the moral predominate should have their large place in national councils and public discussions, it is the duty of every man with influence in public life to press to the front the great abiding projects which have their root in eternal right, and here Quaker traditions and principles should make a prepossession in favor of such a course of action.

There are a number of reforms which have been their concerns very largely in the past. The substitution of life imprisonment for capital punishment, the development of the reformatory idea in prisons and kindly treatment in asylums, the one-price system in sales, the limitation of fortunes and expenditures within moderate dimensions, theories of education which are at once practical and spiritual, the rigidly honest management of public funds, all of these, in which good men generally would join, have some of their roots in legislation, and if not national party issues, not infrequently become the issues in State or local elections or legislation.

Then there is the great question of warlike preparation and policy. This is the rock on which Quaker participation in politics has usually been shipwrecked. It broke its control in provincial Pennsylvania. It drove the Society back into itself in the Revolutionary War and pro- 
duced an inwardness from which it has only in the last half century evolved. It forced John Bright from the British Cabinet when Alexandria was bombarded. It caused the breaking of the property of Joshua Rowntree in the Boer War. It has sent many a conscientious sufferer to jail rather than pay military fines or join in military exercises. In wartime it operates to render pacifists objects of unpopularity among a great host of men, some unthinking and hysterical, some seriously concerned for the national safety.

Here is the great problem of to-day for the Christian statesman who can maintain himself conscientiously in public life. He needs to show the nation that an aggressive policy of goodwill, the absence of all design on the integrity or interests of others, the rigid and even generous enforcement of all treaties and conventions, the full comprebension of and respect for the points of view and political and commercial interests of others, are worth more in maintaining peace than dreadnoughts or submarines, coast defences or standing armies. Had we the greatest armaments in the world, which after the expenditure of billions of dollars and years of times we might have, with all the military spirit and commercial interests necessarily developed by such an aggregation, who could trust the nation not to enter with slight provocation upon a career of conquests or overbearing treatment in the cause of mercenary or political interests! The danger of foreign aggression upon a nation doing its generous part in world diplomacy, upon whose goodwill the commercial prosperity of all others was largely dependent, is far less than the danger, under the guise of preparedness, of ereating a spirit of militarism, which will break down our Christian standards and lead on to a cataclysm such as a similar spirit has developed in Europe.

The ideal Friend stands for the development of person- 
ality. For this he can not go to war, for this involves the subordination of personality to human commands, doing evil that good may come, the merging of the individual conscience into the conscience of the mass. He can not swear for his every word has the sanction of truth behind it. He can not be an unquestioning member of a political group taking on or leaving off principle at the behest of a leader or of utilitarian considerations. He can not grind the poor in business or the criminal in jail, for the respect for his own personality induces respect for that of others. He must go through life more or less isolated, not from lack of sympathy for others, for he ought to have this in the highest degree, but because the machinery of modern methods is too rigid for his open-minded and independent soul. $\mathrm{He}$ will take his orders from his own discerning heart rather than from current opinion or popular impulse. "The method of Christianity does not lend itself to those accommodations and compromises without which nothing can be done in politics."

If he can do all this and still be an effective public servant, as an exceptional man in an exceptional place may be, the Quaker in politics may live. If not he will sacrifice place to conscience, expediency to principle.

These pages will show to what extent the prominent agents in carrying Friendly principles into effect in the politics of provincial Pennsylvania accomplished their purposes. In varying degrees their public careers were mixtures of idealism and opportunism. But the most "practical" of them showed some effects of the spirit of Quaker teaching, which modified their actions, and cut out lines of effort which promised valuable results.

In the application of certain principles they were pioneers. Their experiments have been justified by the results which followed. No other founder than William Penn, except on 
a smaller scale Roger Williams, adhered more generously to the ideas of religious and civil liberty and the separation of ehurch and state. His followers proved the utility as well as ideal rectitude of the principle and prospered greatly as a result. No other colony treated the natives so justly or reaped so much peare and healthy development or drew in as a consequence settlers and wealth so rapidly. Their position with regard to oaths, which they adhered to tenaciously, has been illustrated by recent tendencies which show at least that the affirmation is equally effective in securing veracity and fidelity to duty. Their early penal system, excepting their unfortunate lapse in the matter of capital punishment for minor crimes, was governed by the ideas of reformation and leniency which lie at the basis of the best modern methods. They were a century ahead of their time in seeing the evil of lotteries, and prohibiting them. In an age when piracy and prize goods were common they bore an unflinching testimony against them in all forms. The colonial Quakers took an ever developing part against the slave trade and slavery and laid the foundation of the public sentiment which made Pennsylvania the first state of the Union to pass an abolition law. They had the institution nearly exterminated in the north when the Federal Constitution was adopted. John Woolman, Anthony Benezet and their friends keeping on moral grounds rather than economic were ceaseless in urging the fact that property in man violated inherent right and Christian principle.

Their position with regard to war scems not to have been indorsed by the general practice of the future. Its essential cruelty and immorality are by most people, including Christian ministers, justified by the necessities of the case and the misfortunes which would seem to result from its abandonment. All recognize its evils and long for its abolition but find in concrete cases good reasons for adopting it 
as the least of the possible evils. They do not see as the Friends thought they saw that the best thing to do, is to avoid any participation in it as a wrong thing in itself and to trust that somehow in the long run the right would justify itself. This view may yet triumph but writing in the midst of the Great War when all Christian bodies except the Friends and a few other of the smaller sects alone take this position, one can not fail to see that murder and maiming and violation of human rights of all kinds do not seem reprehensible in the settlement of national affairs as they are fully recognized to be in personal differences. Possibly the near future will tell a different story.

Why were Friends able to do even this much of pioneer work in social and moral reform, for in England they could give an equally good account of themselves under less free and easy circumstances?

It was not because of superior intelligence or education though these had doubtless their effects with the leaders of the morement. As a whole they were not highly educated or trained in social or ethical learning. It was not because they were more anxious to do right than their contemporaries, for many of all bodies had motives as pure and consciences as alert. The following answers to the question may be put forward tentatively.

They were not drawn into any movement which promised spectacular results from a supernatural ageney.

The first Christians were so full of the idea of the early "second coming" that the incentive to reform did not exist. What difference did any amount of cruel treatment make to a slave, any inhumanities of government, any horrors of warfare, if all was to be soon set right and a universal reign of righteousness and sinlessness inaugurated by a Divine Being, who would come independently of anything which they could do, their duty being only to 
prepare themselves inwardly for the enjoyment of the happy fruits. Paul did not attack slavery or war or graft as institutions but preached the inner rectitude of the individual. His followers saw in this inner rectitude not so much a means of service to others as salvation for themselves. This it is true lifted men above the plane where the worst evils were possible and so many of them disappeared, but any systematic social reconstruction was not preached. As Harnack says, "The Gospel is not one of social improvement but of spiritual redemption."

One finds nothing of this appeal to such a catastrophic advent in the writings of the Early Friends. The Bible passages referring to it were applied to an appearance of the Divine spirit to individual hearts, leaving them, thus illuminated, to work out their own problems. They turned their minds inward and accepted the responsibility of their actions, not leaving all response to a day when Christ himself would set matters right. They looked and waited for this illumination. Their meetings for worship were not for the purpose of listening to music or sermons, but to a Divine voice in their consciences. When this told them an institution was out of harmony with God's will they wanted no other evidence. May it not be possible that they had a surer support for their social work than the most of us are now willing to admit?

Nor would they grant that any such a task was impossible. Nothing with such a backing could be hopeless. There was no demonic power in "the world" which would not succumb in time to a quiet attack, faithful to death. With hearts open to influence and strengthened by a "will to power" from above, each one was to do his duty as he saw it and the harvest was some day sure. The time came in the history of the Society when a copy of the first testimonies was accepted by the rank and file too slavishly, but 
by this time the testimonies themselves had become traditions and the body remained true to them, while there were always some prophets open to new truths.

Some one said before the war that the "three invincibles" were the Romish Church, the German Army and the Standard Oil Trust. The real Quaker of the olden time would have said that these three would all fall as grain before the sickle in the face of a silent assembly responsive to God's spirit if out of harmony with it.

The same attitude of mind which looked for the second advent in early Christian times is produced by dependence upon the spasmodic "revivals" of modern date to maintain the spiritual life. During the intervals there is a sag, and a comfortable feeling exists that it will be made all right when the next excitement stirs up the emotions. The converts are content not only for themselves but for others to await these determining issues as all-sufficient rather than to engage in serious and intelligent efforts to study the causes of social ills and apply the remedies.

Through the centuries the preparation for the next world has been the governing purpose of Christianity. After about $250 \mathrm{~A}$. D. the monastic movement beginning in the East, borrowed from other religions, had sway over the most devoted followers. Its purpose was a desire to gain heaven for one's self rather than the preparation for service in this world. Its ascetic principle led to the subjection, not the upbuilding, of the body, the elimination, not the proper training, of useful faculties. The more one tortured himself, kept apart from his fellows, subjugated in his own person the world, the flesh and the deril, the more sure he was of eternal reward. If by such means he could perform miracles of healing they were valuable as a testimony to his own holiness, rather thin as helping his more sinful neighbors. Western monasticism was more practical and useful, 


\section{4 POLITICAL LEADERS OF PENNSYLVANIA}

though hardly less ascetic. But its motive was the sameotherworldliness rather than unselfish service. This still persists but happily at more generous view of the utility of goodness now often prevails.

Friends to some extent were influenced by this feeling. But George Fox and William Penn were very practical mystics though they never lost the hope and the belief in immortality. But it seemed to them to come as a natural reward of duty done on earth rather than as something to be striven for in itself. As Whittier, the greatest of modern Quaker prophets, has said:

"So to the calmly gathered thought

The innermost of truth is taught,

The mystery dimly understood

That love of God is love of good.

That to be saved is only this

Salvation from our selfishness.

That book and church and day are given

For man not God, - for earth not heaven;

The blessed means to holiest ends,

Not masters, but benignant friends:

That the dear Christ dwells not afar,

The king of some remoter star,

Listening at times with flattered ear,

To homage wrung from selfish fear,

But here amidst the poor and blind,

The bound and suffering of our kind,

In works we do, in prayers we pray,

Life of our life, he lives to-day."

Hence their obligations were never dulled by a feeling that the progress of humanity was of less importance than their own freedom from penalty. The nether world was not described in their writings in the lurid pictures else- 
where seen. The punishment they preached was the loss of fellowship with the Father; their Heaven was the completeness of this fellowship. Silvation eame with a redeemed life, a salvation from sin as well as from future punishment. The life and death of Christ reproduced in themselves, with them, as with him, sent them out to heal and to help bodies and social conditions. The ideal Quaker of the John Woolman type lived a life of close communion, of great searching of motives, of intense desire for purity of heart, but for the sake of never ending helpfuhness towards the worldly as well as the spiritual conditions of others. "They were saved men themselves before they went about to save others" is a Quaker classic. The inner religious experience was the basis of service. Political and economic considerations were secondary though helpful. In this way only can the old Quaker conception of inwarlness be linked with the modern study of economic law and social justice.

They preached also as necessary a continuous experience of Divine support and education. It was not merely one or a series of spismodic influences, renewable at the pleasure of the individual, and independent of duty performed in the intervals. It was rather a consistent spiritual impulse, not always equally strong, which condemned every shortcoming and gave its peaceful reward to every faithful response to a call to service; which was clarified and strengthened by obedience and exalted by fidelity. So came the Quaker conscience; to its possessor the greatest thing on earth; faulty in discovering fully absolute truth, but simply another way of saying that in every emergency of life a man must do the best he knows and feels and omit a calculation of consequences. So every call to duty no matter how slight the duty might be, became as the apple of his eye, worth loss, worth suffering, worth imprisonment, 
worth death itself. His grip on a line of service could not be shaken off by threat or argument but he would persist with quietness and confidence, without bravado, "with charity for all, with malice toward none, with firmness in the right as God gave him to see the right."

A statement of principles should be but a cross section of a developing belief. Like all human institutions it changes with time. If it becomes fixed and necessary it becomes a creed and fetters progress. Men must conform their mental operations to its meaning. With much that is true, in time it may be inadequate or erroneous. It may become an object in itself and all movements be gauged by the efforts for its maintenance. Social movements which do not seem to conform themselves to it, are judged adversely by its standard, itself only a secondary presentment of a prior belief. This is true whether it be an edict of some old council, or a collection of biblical passages, stripped of their context and real meaning.

There never was a Quaker creed. In theory at least the free spirit of Christ was an ever new source of revelation. There were no Quaker ordinances essential to the spiritual life. The way was open for changing statements and symbols to suit advancing thought. It was not necessary to adopt or follow any ritual. George Fox did not mean at first to found a sect but to infuse a certain spirit into all Christian believers. It is true that crystallization came in time, that forms supposedly essential were developed and that doctrines almost credal in their tendencies became largely prevalent. The dead times of Quakerism were those when the spirit and personality of Christ became so merged with tradition and custom and fixed belief that the freedom to progress was hindered. But it was never quite lost.

One must be appreciative of the fact that the above is 
rather an ideal, than an actual statement of Quaker conditions; that the body was never fully permeated with the liberty to attack moral evils and appreciate moral truths at their real value. But there were always some who did so appreciate them and they pointed the way. But elearly or dimly as such lights were seen it is possible that they were bright enough to enable the Soeiety of Friends to act as efficient preeursors of certain social reforms; which gave them a sense that liberty and justice and peace and kindliness were worth striving for, and which showed them how to work wisely and effectively for a religion which touched men's lives in this world and helped bring about the Kingdom of God on earth.

They lost strength at times by the prosperity which came with respeet and success; by theories of living devoid of experience; by minimizing the power of Jesus Christ; by the use of forms after the life had departed from them; by neglecting to revise their testimonies to suit new conditions; by a distrust of learning and the experience of others. Their weaknesses and their strength are both full of meaning. The one hindered their growth and influence, the other has kept them alive, even when, as in war times, they have run counter to public opinion and prevalent Christian sentiment.

In summarizing the sourees upon which the early Friends based their attitude to moral reforms, and which brought them whatever measure of success they had the following may be considered:

1. They judged questions by moral principle rather than by expediency.

2. They depended on a continuous moral edueation through direct Divine ageney rather than on spectacular displays of Divine interference for which they were not responsible, to set things right. 


\section{8}

3. Their religion was intended to be practical as applied to the affairs of this world and not useful only as a preparation for the next.

4. They were not bound by a closed creed or tied to a ritual which prevented adaptations to new conditions and new revelations of truth.

5. They were willing to admit the supreme authority of the New Testament in its spirit and methods.

Many are sceptical as to the ability of a minister of old time "to speak to the condition" of an individual unknown to himself previously. There is great possibility of selfdeception but there seem to be too many well authenticated cases to doubt the reality of such revelations. One is, however reassured when a man so accustomed to weigh historical evidence and so fair and open-minded as Dr. Thomas Hodgkin, himself a Quaker minister, writes as follows:

"And though I have heard many rambling discourses which showed rather the desire to be helpful than any real power of helping . . I I am on the other hand fully persuaded that in many cases, a knowledge of the needs of the congregation or of some individual member of it, which was not in the intellect of the preacher has been by some spiritual process which I do not pretend to explain, but which I belicve to be God-guided, conveyed into his mind during the preparatory time of silent waiting upon God." 1

And again,

"Not so the early Friends. It was surely a heaven sent instinct which restrained them from calling the Bible the Word of God." 1

Is it a far cry to extend this principle from individual to group illumination? To believe that when a company of dedicated souls sitting in quiet with all worldly roices

${ }^{1}$ Life of T. Hodgkin, p. 333.

${ }^{2}$ Ibid. p. 340. 
and desires hushed, unitedly expecting instruction from above, and their whole being attuned to its reception and awaiting its deliverance, should have "the feeling which is evidence," that their community duties pointed in a certain direction? Is there not historic evidence enough, that here is a factor of enlightenment which in our inquiries towards the ways and means of social betterment should not be left out of account?

We may assent to this, but in modern times we hardiy practice it, when we talk, for instance, of social justice to the wage earner. We find the two lines of argument set against each other. Our ancestors have often denied the economic reasonings which appeal to us; also our ardent and devoted missionary friends tell us that all good things will follow real Christian experience. Many workers, on the contrary, say that laws as immutable as gravitation determine sociological conditions, that it is our duty to find and apply them, and that Christian experience has nothing more to do with it than with the movements of the planets. If we could join together on the one hand the sources of enlightenment which seem to have been effective with Friends of the past, and on the other the modern ideas about the reign of law and the lessons of history as contributory and influential, such a union would be irresistible. 


\section{WILLIAM PENN}

IT is not the purpose of this sketch to give even in broad outline an account either of the life or the writings of William Penn. His many biographers have amply attended to the former and the latter are too voluminous and disconnected to be mentioned even by title. We shall confine ourselves to a brief estimate of his character and abilities and the political ideals which he sought to introduce into the life of his Province. The veneration in which his name was held, and the beneficent results of his policies and principles became after his death, most intensively within his own denomination but not confined to it, the origin of almost too great a reputation for sanctity and wisdom, and leavened the life of the province throughout its whole history.

His biographers have copied from each other and perhaps too carelessly accepted tradition as to some events which have not stood the test of closer examination; but enough of well authenticated facts, letters of himself and judicious friends, epistles on religion and government, and the undisputed actions of his public and private career, exist from which to frame an estinate of his strength and his weakness.

Hepworth Dixon and others seem to have effectually answered Macaulay's charges to his discredit. It is unfortunate, however, that they are embalmed in that historian's brilliant style and perennially interesting volumes. 
Where a score read the attack but one knows of the defence, and so the misstatements will for ever be renewed and believed.

There are, however, certain weaknesses of Penn's character, not seriously discreditable to him, but which detract something from the universal praise often accorded him. He was a poor judge of character. His Deputy-Governors were often most unfortunate selections. Blackwell, an old Cromwellian soldier, honest and moral, had no appreciation of the Quaker character with which and over which he was to govern. He was, as he admitted, "unequally yoked" and "unfeignedly gave thanks to God" when he was recalled. Evans, a young libertine, swollen with a puerile sclf-conceit, offended in every way his best friends and made endless troubles for Penn. Gookin, severe and unyielding, with a stubbornness lapsing into insanity, was an unquestioned misfit. The better judgment of Penn's widow saved the day for the family after this succession of failures.

It is true the problem was a hard one. A Friend would not perform the duties which involved certain military declarations and offices; these they were quite willing that others should undertake, but against them their own consciences rebelled. The Deputy-Governor must, therefore, not be a Friend. He must, however, be acceptable to them, appreciating their spirit and respecting their scruples, for by virtue both of numbers and character they controlled the situation. They were to be his partners, not his subordinates, and with the extravagant idea of their rights and privileges which some of them had, they were no easy partners to work with. The ideal Governor must not only be self-respecting, but tactful; not only a strict moralist, but tolerant of differing standards; not only faithful to Penn's interests, but appreciative of the people's liberties. Not 
one of Penn's choices, with the possible exception of Thomas Lloyd, possessed all these qualities, and bitterly the proprictor paid the price of his poor judgment in thirty years of governmental confusion and financial loss.

The account of Penn's relations to his knavish steward is not pleasant reading for his friends. Ford was a Friend and a business man of ability. Penn placed all his affairs in Ford's hands and dismissed his care of them. Full of great schemes of philanthropy, his influence eagerly sought for suffering Friends and suitors of all kinds, this is rot a matter of wonder. But when the fraudulent nature of Ford's doings was known to Penn, or might easily have been known, he still allowed matters to proceed, heaping up claims till the province became mortgaged and his friends had infinite difficulty in untangling the complicated fraud. At first it was misplaced confidence, which any busy man might have fallen into. Then lest the plight which had happened to him should injure the Holy Experiment, he allowed it to proceed and kept it quiet, thus piling up untold suffering and trouble and a term in the debtor's prison for himself, and much vexation and expense for his friends which an earlier, vigorous exposure might have avoided. There was nothing dishonest or illiberal in his course, only a suggestion of a lack of downright positiveness in extricating himself honorably from an unfortunate position.

The question of military resistance was the great difficulty in a Quaker state, which finally wrought the political downfall of the body which opposed it. Just prior to the downfall, the Friends had, in many cases, held their places by pursuing what seems like a doubtful course, going further than strict consistency would approve. Penn himself was not quite clear of some equivocation in the matter. As we have seen, he appointed non-Quaker deputies to perform acts which he and no other Friend would consider 
consistent with their profession; to "be stiff with our neighbours upon occasion" as he once said.

This may be defensible, for liberty of the individual conscience was their great claim. But when Penn recovered his right to govern his province in 1693 , it was the result of a promise that he would faithfully transmit to the Assembly all kingly commands for military aid, which " he doubted not" that body would honor. It did not honor the first communication he made in compliance with this implied contract, and Penn must have known that it would not and that he would not urge it to.

Fortunately the trouble was only ephemeral, and no one called for a literal enforcement of the condition, but this hardly acquits Penn of something like hedging in his dealings with the Crown, a stroke of diplomacy very venial in that day, but not quite consistent with an open and perfectly transparent character.

These, then, seem to be the weak spots in Penn's record, an inability to judge men and a certain timidity in dealing with difficult situations, when his larger plans would be thereby endangered. More than this can hardly be fairly charged against him. These were the causes of the most of his troubles. Good deputies and bold strokes to rid himself of the webs of chicanery his personal and political enemies had woven around him would have kept the temper of the colonists sweet and loyal and his own actions free to carry out his plans. When he went to jail for a matter of conscience, every one of his friends must have felt a thrill of pride as he declared: "My prison shall be my grave before I will budge a jot, for I owe obedience of the conscience to no mortal man." But when he sent out his frantic appeals to Logan to gather in his dues, and allowed his friends to raise a subscription to pay off the indebtedness he had unwittingly contracted, when he lay months in Fleet prison 


\section{POLITICAL LEADERS OF PENNSYLVANIA}

waiting for his ereditors to come to terms, there must have been a loss of respect among those who looked to him for leadership, even though these were recognized as under the circumstances right and neeessary things to do, and to be the result of no moral obliquity on his part.

The other side of Penn's character is more pleasing to contemplate, and so much more impressive that the flaws seem insignificant. He was profoundly and sincerely religious, and his personal life was far above the ordinary vices of his age. This was questioned probably but once. When a persecuting Judge suggested that the early career of the prisoner had been guilty of some of the sins against which he was declaiming, Penn indignantly denied it and challenged any one to prove that by word or deed he had, even in his more thoughtless youth, ever offended against the standards of a strict morality. The Judge was rebuked by a fellow judge, who admitted the truth of Penn's denial and told his associate that he had gone too far. The truth of the declaration may well be admitted. Only purity of life, or areh hypoerisy, could be the basis of such beautiful precepts of morality and piety as we find in his writings, and the latter alternative will hardly be claimed by any one.

The wisdom of many of his Fruits of Solitude, the fervent appeal to the reader at the beginning of $\mathrm{No}$ Cross, No Crown, the fitting and eloquent eulogy on George Fox, and many others which will oecur to any reader of his works, could hardly be the product of a character which had ever suffered a moral relapse. Nor is there evidence that the validity of his inspired ministry or the profound respect and influence accorded to his preaching was questioned by his rather exacting collaborators in the Gospel among Friends. It is no proof of this that crowds flocked to hear him in England when he was expected to be present at a 
meeting, for this is the meed of every preacher who has for the time being the popular ear.

A better evidence is the judgment of friends expressed in private correspondence. Isaac Norris wrote in 1701, just as Penn was leaving the province the second time:

"The unhappy misunderstandings in some and unwarrantable oppositions in others have been a block to our plenary comforts in him, and his own quict; but these things are externals only. Our communion in the church sweetens all, and our inward waitings and worships together have often been a general comfort and consolation; and in this I take a degree of satisfaction, after all, that we part in love; and some of his last words in meeting yesterday, were 'that he looked over all infirmities and outwards, and had an eye to the region of spirits, wherein is our surest tie '; and in true love, there he took his leave of us."

Again in 1707, when the proprietor was in the darkest days of his difficulties with the Fords, Isaae Norris writes:

"The more he is pressed, the more he rises. He seems of a spirit fit to bear and to rub through difficulties, and after all, as thou observes, "his foundation remains.'"

William Penn was one of those choice beings whose soul was attuned to Divine harmonies, and whose power could be felt by kindred spirits in the life of Christ. When he was coming to Pennsylvania in 1699 , he received three certificates from his Friends in England, one from "the Second-day's Mecting of Ministering Friends," in London, one from the Friends in Bristol, where he had resided for a considerable time, and one from the Monthly Meeting of Horsham. They are all most appreciative. The last tells of -

"Our unity and communion with him. ... He had been a holy and blessed instrument in the hands of the Lord, 
both in his ministry and conversation (conduct) and hath always sought the prosperity of the blessed truth and peace and concord in the Church of Christ; and walked among us in all humility, good sincerity and true brotherly love to our great refreshment and comfort."

There was some adverse sentiment. In Pennsylvania, this had, to a large extent, a political basis, and was led by David Lloyd and Griffith Jones, both probably estimable men, but whose extreme demands created a partisan feeling that extended into the meetings. ${ }^{1}$ These men were correspondents and in sympathetic relations with William Mead and Thomas Lower, who are spoken of in the letters of the day ${ }^{2}$ as representing the opposition party. George Whitehead is often associated with them.

This opposition from within was largely due to Penn's supposert aristocratic tendencies and possible departure from a proper simplicity in his relations with the courtly influences among which he moved, and also to the Ford

1 "Our meetings for business are now so much injured by some young forward novices and a few partisans of D. Lloyd, still a close member, that the more sound and ancient Friends do not venture upon anything there that concerns the government, expeeting a separation upon it whenever it is taken in hand. Aceording to present appearances of things, a separation will in time be unavoidable, and that after Friends (in England) have taken notice of proceedings here, nothing less than a general purge will ensue. J. Logan, 4 mo. 28, 1707."

2 "There is a short communiration held between thy opposites among Friends there and that corrupted generation here. G. Whitehead has wrote a most affectionate letter to Griffith Jones. He expresses himself as thy friend, but we know how he is linked with the Meall and Lower Party. I believe George is mistaken in Griffith, and knows not that he is not received in unity with Friends."

James Logan to William Penn, 6 mo. 10, 1706.

"They address such on this side the water (England) who are julged by them to be not in the best understanding with him."

I saac Norris to Joseph Pike, 1 mo. (March) 18, 1707.

See Penn and Logan eorrespondence. 
question and the doings of Evans as deputy-governor. It was later swallowed up by the prevailing and warmly expressed regard, as these matters were seen to be perfectly consistent with his profession and exalted character. After 1710 , both the personal and political antagonism largely ceased in Pennsylvania, and those who had been considered as opponents lost their influence. The English opposition, always less well defined and based on more shadowy grounds, seems also to have disappeared about the same time. So that, cleared of his financial troubles, his colony loyal, and his enemies evanescent, he spent the last two years of his vigorous life in a serene atmosphere of success and triumph. The stroke that then deprived him of his mental power, but left his spiritual faculties unimpaired, brought him universal sympathy and appreciation.

Mentally, Penn was one of the great men of his times. It was a day of young men. The great preachers were nearly all under thirty, but this might be consistent with ordinary intelligence. Penn was more than a great popular preacher. He was a man of great thoughts and far-seeing plans and definite and courageous convictions based on learning and experience and study. He was ready for Oxford at fifteen. He was but twenty-three when the germ of the principle of universal toleration seems to have taken possession of him, apparently evolved from within, which in time became the great enthusiasm of his life. At the same time he began to preach. The first of his religious works came a few years later, and No Cross, No Crown immediately followed. The erudition displayed by one so young was a surprise to friends and enemies alike. Thus, at the age when the average American youth is finishing college, Penn had collected a wonderful store of knowledge, could command an effective English style, and was a master of theological arguments of a most serviceable quality. 
His development was continuous. His work on constitutions prior to his American experiment betrays the thoughtful student of the best that had been written in the past. He always had great conceptions and projects. In 1693 he published his scheme for "An European Dyet, Parliament or Estates," to which disputes between nations should be referred. All the great Powers were to be represented. The advantages of such a court, and the means to make its decisions acceptable, in order to avoid wars, were presented with great wealth of argument and illustration. The Hague tribunal was there in embryo.

Three years later, he published a plan for the union of the American Colonies. Two representatives of each province were to meet in New York to arrange matters of common interest. They were to settle questions concerning commerce, the return of criminals, and "consider ways and means to support the union and safety of these provinces against the public enemies." This was probably the first suggestion of the movement which culminated about a century later in the Federal Constitution and Union.

But the greatest and at the same time most practical conception was the foundation of Pennsylvania itself. That there were errors in detail, none can doubt. An absentee landlord, even though liberal, can hardly avoid eriticism and opposition, and such was William Penn to his colony. His forceful presence would undoubtedly have composed faction and removed difficulties, and it was his full purpose to have lived permanently in Pennsylvania. The idea of a commonwealth devoted to liberty and peace drew out the best powers of a comprehensive and enthusiastic intellect. There was no room in Europe, but in the great unoccupied expanse of the New World he would carry out his ideals with a selected community in sympathy with them, of a serious and honest sort, to whom he would transfer the 
government power and realty rights he had purchased of the Crown, rescrving only such moderate share of each as security for the future and family interests would justify. It was a glorious conception and a no less glorious opportunity, and we find him continually tempering his natural ardor by considerations of duty to God and man, as the seriousness of the task and the risks of failure pressed themselves upon him.

There was, too, in his composition a good share of fighting spirit. He was to have difficulties, but he never quailed. The temper which declared that he would never yield a jot, even though he died in prison, served him in good stead in other contests. "Can my wicked enemies yet bow? They shall, or break, or be broken in pieces before a year from this time comes about, and my true friends rejoice," he declared in a crisis with Lord Baltimore. "If lenitives will not do, coercives must be tried," he announced in another emergency. It was only this determined vigor which carried him through the vast heap of difficulties among which he struggled.

The whole of Penn's life indicates the power of his personality. Where he was present, events shaped themselves towards his purposes. At the courts of Charles II., of James II., and of Anne, he had surprising influence. This is all the more remarkable because his Quaker scruples in certain respects must have removed him far from the ordinary courtier. We may assume that his dress, while simple, was comely; that his speech, while observing the limitations of his sect, was well chosen, pleasing and appreciative of the point of view of his associates; that his manners, while devoid of the flattering postures and phrases of the day, were never offensive. It is only thus that we can explain what seems his general friendliness with royalty and nobility. "I know of no religion," he says, " that destroys cour- 
tesy, civility and kindness," and these qualities, together with a conversation full of interesting matter and a ready wit, seem to have made him generally acceptable. So it was that he interceded successfully at court, not only for hundreds of persecuted Friends, but for Anglican bishops, political refugees, and suffering scholars, as well as crowds of needy suitors of humbler rank.

It was for these purposes, and to counteract the influence of Lord Baltimore in the matter of the boundary line, efforts which never failed of success, that he felt inpelled to remain so much in England. Again and again he hoped to come to Pennsylvania, but the demands of Friends and the exactions of Ford kept him at home. Only two visits of less than two years each, all too short for the work to be done, was he able to make to his province.

His personal influence was no less marked among his colonists. When present, faction was stilled, the Indians were pacified, desirable legislation was effected, and under his ministry the meetings settled down into quietness and harmony. Could he have longer remained, another history would have been written. Perhaps it was well that in the tutelage of the colony it should have been left to its own responsibility, and have found its way through confusion to liberty. For had the compelling influence of its founder been continually present, a heroic figure among his friends, certain aristocratic features and social customs might have been engrafted on the government less favorable to liberty than such as were worked out through the stress of partisan conflict. Whether we sympathize with David Lloyd or William Penn in the struggle between them, we may accord to each of them a potent influence in shaping the free government which grew out of the troubled early years of the experiment.

There are many traditions of his life in America: how he 
outjumped the Indians, and gained their lasting regard; the great treaty immortalized by Clarkson in history, by West on the canvas, and by Voltaire in happy phrase; the open house at Pennsbury, where in feudal style he generously entertained red man and white, politician and minister alike; his "walks" with the Indians and the regard he showed for their prejudices and customs; how on his way to Haverford Meeting he took upon his horse little Rebecca Wood, and carried her with him to the Meeting, her bare feet dangling on either side; how at Merion a little boy, curious to see the great Governor, peeped through a hole in the door of his chamber, and saw him on his knees returning thanks that he had been provided for in the wilderness. There is probably more or less truth in all of these. They show that in a little time something of a halo gathered around his name, and his little acts became significant, a sure evidence of influence.

We may make such surmises as we will concerning the extent of the influence of William Penn upon Pennsylvania Quakerism, based on his character and standing. The Meeting minutes make but limited reference to him. In 1683 a plan, doubtless originating in William Penn's comprehensive mind, was presented to the Meeting:

"It being desired to hold a general Meeting of Friends from New England to Carolina, the Meeting appoints: William Penn, Christopher Taylor, Samuel Jenings, James Harrison, Thomas Olive, Mahlon Stacy, to make arrangements by writing to Friends or speaking, and inform London Yearly Meeting."

What difficulties prevented the realization of this project for nationalizing the Society of Friends, we do not know. They were probably material, rather than political. What different development would have resulted is also a matter of conjecture. Something of the same idea occurred 
to certain Yearly Meetings about two hundred years later.

In 1700 , on the occasion of Penn's second visit, we have a record of certificates concerning him being received from Bristol, London, and Horsham. In the same year "Governor Penn" was appointed on a committee to draw up the epistle to London Yearly Meeting. The next year the following minute was adopted:

"Our Governor, William Penn, having said before this Meeting that he entends for England, and desires that they would appoint ten or twelve Friends to meet him this evening upon some weighty occasion, in order thereunto, Samuel Jenings (and fifteen others) and such public Friends as have freedom, are desired to meet the Governor accordingly about six this evening."

This meeting is probably referred to in the letter of Isaac Norris, already quoted. No other references to him appear on the Yearly Meeting minutes. We may safely assume, however, that he was an important figure in any meeting which he attended.

In the minutes of Philadelphia Monthly Meeting, there are evidences of his interest in the details of society work and his name appears occasionally. On Eleventh-month 1st, 1683 (January 1684):

"A letter of advice from the Governor was read to Friends councelling them to be careful in their behaviour for Truth's sake, that so the Lord might not be dishonoured and the Truth evily spoken of amongst wicked men."

Again on Sixth-month (August) 5th, 1684:

"The Governor being present, and his departure for England drawing nigh, he moved the Meeting to give him a certificate as touching his demeanour amongst the people of his province, which was taken into consideration by the Meeting."

And later in the same Meeting: 
"A certificate was drawn up in the Meeting according to the motion of the Governor, and subscribed by Thomas Lloyd (and fifteen others) in the name of the Meeting."

During his second visit, he expressed to the Meeting a "concern" that religious work should be done among the negroes and Indians. Acting on this the Friends appointed a Monthly Meeting for negroes to which their masters were to send them, and "be present with them at said meetings as frequent as may be." It was also agreed that when Indians are in town they be invited to a meeting "when our Governor is willing to speak to them."

He worked on ordinary committees, as in the case of the widow of Thomas Lloyd, who thought that the executors of his will had not treated her fairly. The Governor being present on another occasion, "readily condescended" to give the materials of the meeting house, erected where the City Hall now is, to another in a more accessible part of the city.

When he left in 1701 , never to return, though he and they hoped otherwise, another cordial and loving certificate drawn up by Thomas Story, Samuel Carpenter, and Griffith Owen, was given him.

The personality of William Penn may well be assumed to be the most potent influence in the early history of his province. His advantages of birth, fortune, and education, his superior intellectual and moral powers, his position as originator of the conception which had given to all its members their worldly and religious opportunities, his authority as Governor and Proprietor, would in any community have endowed him with a towering ascendency. But when to these are added a humility in religious affairs, which asked and would allow no precedence, a record of faithful adherence to principle through losses and imprisonments, and an endowment of a prophetic gift of remarkable fervor 
and power, there is no need to doubt that whenever his gracious presence could be felt, nothing could ever compare with it. Even in his absence, his words and memory and spirit hovered over his province in its religious life, and became, long after his death, its inspiration and guide.

From Plato to H. G. Wells many paper constitutions have been drawn up. Utopia, Oceana, The New Atlantis, Looking Backward and a host of others have described ideal bases of government. Whether they would work or not has never been ascertained for they were never as a whole put into operation by their authors or others. Doubtless they have supplied ideas and developed the conditions which have created successful commonwealths. In this way they have fulfilled their function. William Penn alone seems to have been able to perform the double duty of working out a scheme in theory, and putting it into successful action in a new country. He advised with the republican Algernon Sidney, with his Dutch friend Benjamin Furly and others, but primarily it was the result of his own studies and observation. Out of this mass of cogitation and advice came his first constitution, still in paper existence with marginal and interlinear corrections in the handwriting of himself and others.

He wants "that manner or frame of government that shall preserve magistracy in reverence with the people and best keep it from being hurtful to them." He thinks that the Hebrew and English types afford the best models, but "It were a most condemnible superstition to perpetuate anything for being ancient or domestic that were not otherwise useful." Then he enumerates, first as always, religious liberty, "As every person shall in conscience believe is most acceptable to God." There shall be a law-making power meeting annually and adjourning at its pleasure with "Whatever is the privilege of an English House of Com- 
mons." Each member shall bring a written body of instructions from the electors and if it shall so happen that he act contrary to the same then "HIe never more presume to stand unless the people sensible of his repentance shall forgive and choose him." 'There shall be no imprisonment for debt for small sums or capital punishment for small crimes. Oaths shall be abolished. There shall be no taverns or ale-houses, nor any provision for plays, cards, horse races, etc. All children shall be taught trades when twelve years of age, girls as well as boys.

A number of changes were made in this before coming to America and the first twenty years after the settlement saw several constitutions placed on trial. The final one given during his second visit here in 1701 lasted till the Revolution and is exceedingly simple.

There were nine articles.

The first decreed religious liberty.

The second required a free Assembly with full liberty to make laws.

The third directed that two men should be elected for local offices from whom the Governor should choose.

The fourth required all laws to be passed upon by the Governor.

The fifth secured the rights of criminals to a fair trial.

The sixth gave to the courts and not the Governor the rights to decide all property cases.

The seventh demanded good morality of the applicant for a tavern before license could be granted.

The eighth prevents the forfeiture of the estates of suicides and required a six-seventh vote of the Assembly to amend any clause. 
The ninth declares that the clause relating to religious liberty will be preserved forever by the proprietor and his heirs.

On this basis of elementary right the government of Pennsylvania for 75 years worked with success and a prosperity unrivalled among the colonies.

The great enthusiasm of William Penn's life was for religious liberty. It was just beginning to find a voice in Europe in his time. Holland was leading the way and Roger Williams who was an English pioneer had in 1644 published his "Bloody Tenent of Persecution for the Cause of Conscience." Here the arguments for the free enjoyment of one's own religious convictions and practices were given with great liberality and learning. Nor did he shrink from the full application of these prineiples when he founded his Rhode Island Colony. Toleration, which implies a favored church and permission to others to exist, was as far as the more advanced thinkers had elsewhere gone. Massachusetts and Connecticut rigidly excluded dissenters from the franchise and demanded of them taxes for the support of the state religion. Physical cruelty was the penalty for the free exercise of their worship by the Quakers of Massachusett's and they with Baptists and Episcopalians were banished. The Church of England was established in New York and the South, and, save for a time in Maryland under Catholie rule, there were disabilities and fines for dissenters.

Penn grasped the idea in its fulness and his early attempts at a constitution for his colony show how thoroughly he was convinced of its righteousness. But he had to satisfy the court, and by 1701 when his frame had got others, it had received some limitations. 
"I do hereby grant," he says, "and declare that no person or persons inhabiting in the province or territories, who shall confess or acknowledge one Almighty God - and profess him or themselves obliged to live quif!y under the civil government, shall in any case be molested or prejudiced on his or their person or estate because of his or their conscientious persuasion or practice, nor be compelled to frequent or maintain any religious worship place or ministry, contrary to his or their mind, or to do or suffer any other act or thing contrary to their religious persuision. And that all persons who profess to believe in Jesus Christ the Saviour of the World, shall be capable (notwithstanding their other persuasions and practices in point of conscience and religion) to serve this government in any capacity, both legislatively and executively, etc."

That is, Penn opened the door of conscience freely and equally to all religions which acknowledged the existence of a God, and allowed all professing Christians to hold office. This latter limitation, which in his time did not amount to one, was probably a necessity of his English connection.

Later at the command of England, his successors by a test excluded Catholics, who were assumed to be allies of the banished Stuarts, and in league with their great national enemy, France, from the privileges of office holding, without however curtailing the freedom of their worship.

That protection of the Catholies was given is shown by an incident of 1755 after the story of Braddock's defeat had reached Philadelphia. A mob assembled, as the diary of Daniel Fisher says, for the purpose of destroying the "Mass House" for supposed sympathy with the Friends. "But the peaceable Quakers insisted that the Catholics as well as Christians of other denominations were settled upon the faith of the Constitution or William Penn's Charter and that the governments were bound to protect so long at 
least as they remained inoffensive, etc." The Friends were true to the principles of religious liberty of the Founder. ${ }^{1}$

William Penn had been largely instrumental in securing for dissenters in England a certain amount of toleration. This was all he could expect there and the tests there required were forced upon his colonial officials. He would have had them to resist. "Why should you obey any order which is not according to patent or law here, nor the laws of your own country," he writes indignantly from England. This test simply required allegiance and fidelity to the Crown, a denial of papal authority and practices and profession of faith in orthodox Christianity. The Friends could honestly subscribe, but it negatived the application of the broader principle to which Penn was committed, against any religious test. It remained however all through provincial days.

That he would not grant any political favors to his own sect is undoubted. He sends a stinging rebuke to a member who asks whether the founders of the colony should not have such consideration. He gives in a private letter his purpose in this respect. "I went thither to lay the foundation of a free colony for all mankind that should go thither, more especially those of my own profession; not that I would lessen the civil liberties of others because of their persuasion, but screen and defend our own from any infringement on that account." Knowing so well the disabilities of Friends in England he would guard against a rep-

1 The Episcopal minister at Chester about 1740 writes that the Quakers wore encouraging children to leave his school to join one which they had encouraged managed by a "virulent Papist." "They did what none but Quakers clare do in a country under the government of a Protestant king." But something may be charged to partisan zeal in such statements as this. They show however a willingness to extend their idea of liberty to this most suspected of religious bodies. 
etition of them in Pennsylvania, and in guarding it for them he did the same for every one else.

He meant also so far as he was able to provide for the future. After prescribing a way by which all the other clauses could be amended he says: "Because the happiness of mankind depends so much upon the enjoying of liberty of the conscience, as aforesaid, I do hereby solemnly declare, promise and grant for me, my heirs and assigns, that the first article of this chapter, relating to liberty of conscience, and every part and clause therein, according to the true intent and meaning thereof, shall be kept and remain without any alteration, inviolably forever."

Hardly less liberal was his attitude to Democracy. This was abated somewhat in course of time by his imperious need for financial returns from his colony which were rather ungenerously declined, and perhaps also by the aristocratic circumstances of his family which had large influence in English society of the day. But he started with unbounded intentions of radical civil liberty. In his draft of government which he brought from England he allowed himself only three votes in a legislative assembly of 272 members and no veto. The veto power was returned to him and exercised by him and his heirs, or in their absence by their deputies, through all the proprietary years. Then he created a bicameral legislature, the appointed Council proposing all legislation and the elected Assembly passing on it. By gradual encroachment on the power of the Council it was reduced to an advisory body only, after 1701, and the Assembly elected yearly, meeting without call, and adjourning at its pleasure became the free law-creating body responsive to public opinion only. The franchise for the day was liberal, not universal, but with a moderate property qualification. In its frequent contests with the proprietors it won victory after victory for the cause of democracy, 
by bringing popular sentiment to bear, and English fashion, withholding money till privileges were granted.

It was unfortunate that circumstances seemed to place Penn in certain exigencies on the side opposed to democracy. For his early utterances and feelings were far otherwise. He had been an ardent advocate of the election to Parliament of the radical republican Algernon Sidney. In 1676 when he was thinking out a government for New Jersey he said, "We lay a foundation for after ages to understand their liberty as men and as Christians, that they may not be brought into bondage but by their own consent; for we put the power in the people." In 1687 he had printed the Magna Charta with an introduction and comments intended to give his colonists a knowledge of their rights as Englishmen. "It may reasonably be supposed that we shall find in this part of the world many men both old and young that are strangers in a great measure to the true understanding of that inestimable inheritance, that every freeborn subject of England is heir unto by birthright, I mean that unparalleled privilege of liberty and property beyond all the nations of the world outside." Even the jars of the first twenty years did not shake his faith in the people's right to elaim their dues. In 1700 he says with great frankness: "If in the constitutions by eharter there be anything that jars alter it. If you want a law for this or that prepare it. . . I desire to see mine not otherwise than in the public's prosperity."

The demands of ereditors came on him heavily after this. $\mathrm{He}$ needed the reservations he had elaimed out of the colonial income. He had lost a princely fortune by his investment in Pennsylvania and the settlers were slow to pay their dues. They haggled about one privilege after another, mostly financial, until Penn found himself in alliance with the anti-democratic party of the province, and felt 
that David Lloyd who led the field against him for property as well as political rights was a personal enemy as well as a public opponent. But when these petty matters were eleared away his life came out in its true colors as the friend and ehampion of a liberal democracy.

Many letters in existence tell of the large trust of the colonists in him and how potential an element this was in creating prosperity in the colony. About ten years after the settlement Hugh Roberts writes him, "I can truly say that many of us had never eome here but because of the love and unity and confidence we had in thee." Indeed it is not unlikely that the whole Welsh immigration was due to his personality. They were somewhat disappointed beeause the agreement as they understood it of a "Barony," where they could have local home rule after the Welsh fashion, had not been kept and the letter of Hugh Roberts while professing personal devotion seemed to indicate their dissatisfaction.

On the other hand an English settler, John Goodson, writing about the same time, gives a most glowing aceount of the rapidly developing colony but expresses the opinion that Penn ought to be there. "This place is beyond whatever our hearts could have thought of, so that we have no cause to murmur or complain. . . It might have been many hundreds better for thee than it is; for the hearts of many were inclined to this land for thy sake which would and might have come if thou hadst settled here but now will never come if thou comest not." The personality of the founder had in the early days much to do with the suceess of the Holy Experiment.

After the troubles of the early days passed away, troubles which William Penn's presenee in the country might largely have avoided, after the personal differences between Logan and Lloyd, between aristoerat and democrat, had been 
largely forgotten, the name and work of the founder were held in ever-increasing veneration. In 1739 speaker Hamilton, not a Friend, gives an enthusiastic account of the prosperity, freedom and happiness of the people, due he says not mainly to any material considerations but "to the Constitution of Mr. Penn."

About the same date the daughter of the founder, Margaret Penn Freame, in a letter to her brother John urging that a member of the family should live in the province says: "The great regard they (the people) had for our good father makes us welcome everywhere. If I had been the first Duchess of England that title would not have gained me so much respect as the daughter of William Penn. I had the calves of their stalls and the firstlings of their flocks."

There is no doubt that the hesitation of many moderate people to join the American cause in the Revolution was due to the fact that the extremists rather ruthlessly set aside the Penn Charter of 1701 under which they had prospered for 75 years, longer than any other constitution of Pennsylvania existed, and which now had become in their eyes a venerated instrument.

Charles Thompson, "the man who spoke the truth," the master of the Friends Public School, the Secretary of the Continental Congress, the most judicious of the revolutionary Pennsylvanians writing long after the event, of conditions about 1775-6 says: "The original Constitution of Pennsylvania was very favorable and well adapted to the present emergency. The Assembly was annual. The election was fixed for a certain day on which freemen who were worth fifty pounds, met, or had a right to meet without summons at their respective county towns, and by ballot chose not only representatives of the Assembly but also Sheriff, coroner, and commissioners for managing the af- 
fairs of the county and assessors to rate the tax imposed by law upon the estates real and personal of the several inhabitants. Members of the Assembly when chosen met according to law on a certain day and chose their own speaker, provincial treasurer and sundry other officers. The house sat on its own adjournment nor was it in the power of the Governor to prorogue or dissolve it. Hence it is apparent that Pennsylvania had a great advantage over the other colonies which by being deprived by their Governors or their legal Assemblies constitutionally chosen were forced into conventions."

The freedom granted by Penn and enforced by the Assembly for nearly a century, added to the religious objection of the Quakers to war, explains very largely the lack of early enthusiasm for independence in the colony. They were used to liberty of which they had made moderate and rational use, and except for the urgency of Massachusetts and Virginia would probably not have joined the revolutionary party.

But even though the Governor was such a great man the Meetings were not inclined to accord him more than his dues. When he had established himself at Pennsbury there was an island in the river opposite which had been occupied by William Biddle. The main channel ran to the west of the island, thus placing it in New Jersey, but Penn claimed that it had belonged to a tribe of Indians which had also owned the Pennsylvania land adjoining. The controversy went so far as to bring it into the meetings to which the claimant belonged which appointed committees to examine and report. The decision was against the owner and governor of Pennsylvania and the dispute ended.

Penn brought into operation the Puritan notions of the time as to amusements. In the first draft of a constitution before coming to America he prohibited horse-racing, bull 


\section{POLITICAL LEADERS OF PENNSYLVANIA}

and bear baiting and games of eards and dice. It was also decreed that there should be no taverns or ale houses. This last was later softened into a requirement that tavern keepers shall be moral men, an attempt in practice probably more successful than the similar one of the present day. A traveller of 1755 speaks of the "Indian King" of Philadelphia kept by "one Mr. John Biddle, a very civil, courteous Quaker," where no liquor is served after eleven o'clock and everything is moderate in cost. The Friends, however, soon after this came to the conclusion that tavernkeeping was unsavory business for their members and during the Revolutionary War tried to get them all out of it with apparent success. About 1766 the Philadelphia Jockey Club was formed, "Nearly all the principal eitizens outside the Society of Friends belonged to it." Out of deference to this body they adjourned the races during the week of Yearly Meeting.

While Penn and his friends simply transferred to America the common Puritan ideas of a godly conmonwealth as to plays, games and sports, the Friends almost alone adhered to then up to Revolutionary days.

Perhaps it was the idea that lotteries were games of ehance that kept them out of colonial Pennsylvania. A century before they were sufficiently in disfavor in the country at large, to be legislated against, while universities and churches and public improvement generally were building themselves up through their agencies, while George Washington was willing to accept the presidency of a lottery company, while a raffle was a common method of settling an estate, the Friends were adopting minutes against them and the purchase of a ticket was a sufficient cause for disomment. Almost if not quite alone among the colonial sects, no Friends house of worship or school was erected by their aid and no countenance was given to 
state enterprises. Benjamin Franklin forwarded a lottery to raise money for defense but the stricter Friends kept clear of assisting him, objecting as they did both to the object and the method.

The Friends had had a long standing contest against oaths. They based their objections partly on the biblical prohibitions, partly on the implication that they would not speak the truth without them. They were absolutely faithful to this testimony, enduring in England long terms of cruel imprisonment rather than violate it. It was a very simple matter for any inimical magistrate, private enemy or invidious ecclesiastic to offer or have offered the oath of allegiance to the king, and upon refusal, to place them in prison. They would declare their loyalty and challenge their persecutors to prove any flaw in this respect but they would not swear. No testimony of early Quakerism was adhered to more tenaciously in the face of malignant opposition than this.

William Penn himself was in sympathy with this position and meant to relieve them in his province. For a few ycars they had nothing but a very simple form of affirmation and matters went on smoothly. But when nonQuakers came into the province, and Crown officers claimed that their acts could only be legalized by an oath, some change was necessary. Quaker judges and magistrates would not administer them and considerable confusion resulted. In some scetions there were none but Friends competent to perform the duties of the offices. They could cither administer or resign. Penn wrote disapproving both alternatives. He wrote from England, "I desire you to pluek up that English and Christian courage not to suffer yourselves to be thus treated and put upon . . . lose what you lose like men and Christians." Various compromises were proposed but the impossibility of carrying on the 


\section{6

work of a mixed province made some arrangement necessary. A law was passed in 1718 making an affirmation as valid as an oath and affixing the same penalties for lying as for perjury. Friends gave up offices which necessarily involved administering oaths, and others were sworn at their pleasure. Practically the same laws exist in the United States to-day. Whenever however the enemies of Quaker rule wanted to put them out of place, they would send a petition to England to require the taking of an oath as a condition of office holding. It was the threat of such a law passing Parliament that brought the resignation of the Quaker members of the Assembly in 1756. Others besides Friends refused oaths in favor of affirmations, and in the popular mind these were ranked among Friends. But all members who took or administered oaths were disowned by the Society.

By a strange political trade the law of 1718 which granted liberties to Quakers on the subject of oaths included also an increase in the list of capital crimes. By Penn's frame capital punishment was made to cover the one crime of first-degree murder, a notable advance from the English code. Sir William Keith, the Deputy-Governor, suggested to the Quaker legislature that their contention against oaths would better stand against the chance of a Crown veto if it were combined with an extension of the list of crimes punishable by death. The legislature made no objections. The year that William Penn died his mereiful penal code died also and some dozen crimes were added to the criminal list, and so remained through all the colonial days. It seems that the Friends of those days did not place taking life for burglary, rape, arson and so on by judicial process as one of the iniquities against which they must protest with the same uncompromising vigor which they displayed against oaths. 
In the main however they were merciful to the prisoners. The laws made the jails into work houses and reformation rather than example or vindictive wrath was held as the object of detention. Until after the Revolution the penal system of Pennsylvania was held as something of a model. They took also those incapacitated by age or sickness under their care. The first hospital of America was their work, and the "bettering house" for convalescents was unique. Their acceptance of the list of capital crimes seems out of harmony with their general history and came up to plague them when they tried later to argue the unlawfulness of war under Christian standards.

While the Indian policy of Penn has been a large matter of history it probably did not seem to him to be a commanding feature. To treat them with ordinary justice and to convert them to Christianity were what he had in view. As it turned out the latter did not seem nearly so capable of accomplishment through Quaker influence as through Moravian. When the Friends told them that there was something within them which condemned wrong and encouraged right they grunted approval but did not join the Society. They respected Quaker morality and responded to good treatment, but the Moravian Indians were a considerable and loyal Christian group.

Buying their land was not a new thing in colonial America. It had been done at times in New England and New York and more sparingly in the South. The Swedes and Dutch had adopted it in the Delaware Valley before the time of Penn. In fact the Indians sold their rights so cheaply that it was folly for settlers to refuse the bargain. When the Founder instructed his cousin Markham to buy up his provine by piecemeal in advance of settlement he was doing the common as well as the politic thing. He followed this up after he came himself to America only omit- 
ting the strong drink which Markham had included among the purchase goods. He evidently intended never to sell to colonists until all native rights were extinguished, and where two claimants appeared for the same land, as the Iroquois and Delawares for the Susquehanna Valley, he bought of both. This policy worked well in his days for he could readily buy ahead of the incoming tide of immigrants. Later when the great crowds of Germans and Scotch-Irish came in, who cared but little for Indian rights, under the less careful management of his sons trouble resulted. The Indians began to see that they were losing everything and refused to sell and very doubtful measures were resorted to to get a title.

It was not so much the simple fact of purchase or the great Shackamaxon Treaty of good will and amity, immortalized in history and on canvas, which the Indians appreciated, as the fairness of all transactions. This the Indian sense of justice would respond to. They were never deceived by false maps or compass bearings. The measure of land by day's walks was fairly made. Furs were bought by standard weights and cloth was sold by standard measures. While they loved firewater, in their sober moments they would admit that the efforts to keep it from them were dictated by unselfish motives. All this developed in the Indian mind the feeling that Onas and his brethren were really fair minded friends to be trusted; - a feeling which made life secure and easy all through the early days of settlement, which saved the frontier Quakers from the tomahawk when ill-treatment by others had sent the red men on the war path, and which lasted for scores of years when the Delaware Indians were moved first to Ohio, then to Kansas and Oklahoma. Other colonial governments did not start with the idea of murdering the natives or even of stealing their land or supplies. But individual settlers were knaves, per- 
sonal difficulties arose, the whites stood by one another right or wrong, and the trouble led to war for which old testament morality easily found an excuse. Penn restrained his traders. Though pressed for funds he refused to sell monopolies of Indian trade lest advantage should be taken of the natives. An intending purchaser says with some surprise, "He (W. P.) is offered great things $-6,000$ pounds for a monopoly in trade which he refused. ... I believe truly he does aim more at justice and righteousness and spreading of truth than at his own particular gain." This explains perhaps more truly than purchases of land and treaties, the conditions of peace and quiet for so long a time on the Pennsylvania frontiers. Penn practiced only ordinary justice and it is a conmentary on the times that this should have been considered unique.

The relations were almost too friendly. The Indians were indefatigable visitors. The kings and sachems, and a large number seemed necessary to maintain traditions, would camp on the grounds or in the houses of Friends, on every excuse, to be entertained by their rather unwilling hosts. The Friends would not usually supply liquor but others would, and the guests, not always cleanly, were not in the highest degree acceptable. In spite of the verbose and metaphorical illustrations of eloquence of the chiefs, expressing undying gratitude and helpfulness, which the whites would do their best to equal, and the interchange of wampum, such a conference usually ended with a sense of relief on the part of the entertainers. On the other hand it was convenient for the country Friends to leave their children in the care of Indian neighbors, which they did with a feeling of security when they went to Meeting in Philadelphia. Making allowance for differing habits and ideas the relations between the races seemed perfectly natural and such a thing as war was unthought of till, some 60 
years after the settlement, white injustice began the alienation.

The most troublesome feature of Penn's government was one of which nothing was said or suggested in his frame the matter of martial defense. This was left to be decided when the emergency arose. Penn himself had been unequivocal in his condemnation of war in his earlier writings. "If they (the Friends) can not fight for it (civil governnent) neither can they fight against it, which is no mean security to any state." He accepted however in his charter the post of captain general of the army with power "to make war and pursue the enemies and robbers aforesaid as well by sea as by land, yea even without the limits of said province and by God's assistance to vanquish and take them and being taken to put them to death by the law of war, etc." This would seem to be ample authority for a Quaker to fight if he wanted to. He did not hesitate to try to create an ample police force and frequently reproves his colonists for their too easy tolerance of vice. There was considerable pugnacity in his disposition which the exigencies of government frequently excited. He evidently found it difficult to draw the line between a police and an army, as also did his people. They would probably have made a stronger case if they had taken the position that the objection was to the methods of warfare, the killing, the invasion of rights, the hatred engendered, which are inevitable accompaniments, which violate Christ's idea of the dominance of love, and which did not necessarily exist in police duty, exercised for protection of life and property rather than for destruction.

They said in effect: We are not absolute non-resistants but we stop resistance when it becomes in itself criminal according to the moral law as our consciences see it. We do not define the exact line where criminality begins but war 
and its practices are for us manifestly over the line and therefore we can not accept any responsibility.

His great plan for a diet of nations of 1693 to which all disputes should be presented for settlement, a plan far in advance of his times, contains a clause which seems to endorse an international police, which practically would be an army. He says:

"If any of the sovereignties that constitute these imperial states shall refuse to submit their claims or pretensions to them or to abide and perform the judgment thereof and seek their remedy by arms or delay their compliance beyond the time prefixt in these resolutions, all the other sovereignties united as one strength shall compel the submission and performance of the sentence, with damages to the suffering party, and charges to the sovereignties that obliged their submission."

This may or may not mean a military force when political and economic pressure fail. In another part of his scheme we find the following: "Their Saviour has told them that he came to save not to destroy the Lives of Men; to give and plant peace among men; and if in any sense he may be said to send war, it is the Holy War indeed, for it is against the Devil and not against the persons of men." It is evident therefore that even in this great plan so far in advance of his time, so in harmony with the best apparent tendencies of our time, intended to bring actual results among nations as they were, his place for an armed force would be slight.

The basic idea, as nearly as one can tell, of the Friends in Pennsylvania seems to have been freedom of conscience for every one on both sides, on the question of war. They themselves would not serve in an army or support it except in so far as war taxes were so inextricably mixed with others that they could not well draw any line. Rather than do so 
they would give up place, and if necessary suffer distraint of goods. They would also have gone to jail as happened during the Revolutionary War. The supremacy of conscience over any state commands was a well developed and undoubted part of their doctrine.

On the other hand they would not interfere with those who thought that armed defense was a duty. The Assembly refused to enact laws which required men to serve in the militia, because it was known that the Friends would not obey and even if the law made allowance for conscientious objectors, they would not force others to a service which they declined for themselves. Voluntary militia were formed by Franklin and others for frontier protection at private expense, and the only objection made by the Quaker Assembly was to the taking of farm laborers before their debt for passage money, for which they had agreed to work for a term of years, had been liquidated.

Hence appeared the convenience of a non-Quaker Deputy-Governor which Penn provided. He could if necessary raise a militia, or announce an English declaration of war, or build a fort when he could get the means, without any protests from conscience. Thus in 1689 when Governor Blackwell was at the head of affairs, it was proposed that a militia be formed to protect the province against a possible attack by the French. His mixed Council was asked to aid. The non-Quaker part approved. The Friends desired not to be consulted. Samuel Carpenter said: "I am not against those that will put themselves into defence but it being contrary to the judgment of a great part of the people and mine too I can not advise the thing. . . . If we must be forced to it I suppose we shall choose rather to suffer than to do it, as we have done formerly." "We would not tie other hands but we can not act."

Thus matters stood in the following years. The 
Assembly would not vote money for warlike measures directly. Once they extracted a promise from the Governor that " it should not be dipt in blood." Once they sent word to the King that they would obey his commands "as far as our religious persuasions shall permit." Once again they said, "Though we can not for conscience sake comply . . . yet in point of gratitude of the Queen for her great and many favors to us we have resolved to raise a present of 500 pounds."

The usual preamble to a money bill became at a later date "As many of the people of the province are of the people called Quakers who though they do not as the world is now circumstanced condemn the use of arms in others yet are principled against it themselves, etc." This position, that fighting is right for those who thought so and wrong for others, may do for the determination of personal duty, but if they believed that right things were good for the state can hardly be defended. As legislators for the province every deviation from strict rectitude, as they understood it, was in the interests of bad government which they were bound to discourage. It must be admitted however that these early Pennsylvanians were traveling over unknown and difficult ground. It was the first attempt to govern a country on principles of absolute right. They succeeded for 70 years with great success by a reasonably close adherence to principle. Each slight compromise they hoped would be the last. When the line of manifest infidelity was passed they resigned rather than make the further sacrifice of principle.

Liberty and Peace were the two great ideals committed to them. The one has triumphed and become a national, as soon it will be a world ideal. Peace is delayed but it too will be triumphant and it will be recognized that the pioneer work was done in the province of William Penn. 


\section{POLITICAL LEADERS OF PENNSYLVANIA}

Bancroft sums up the attempt of William Penn: "Thus did Penn perfect his government. An executive dependent for its support on the people; all subordinate elective offcers elected by the people; the judiciary dependent for its existence on the people; all legislation originating exclusively with the people; no forts, no armed force, no militia; no established church; no differences of rank; and a harbor opened for the reception of all mankind of every nation, of children of every language and every creed: - could it be that the invisible power of reason would be able to order and restrain, to punish crime and to protect property."

One can imagine with what boundless enthusiasm, with these ideals struggling into action, William Penn in October, 1682, sailed up the Delaware in The Welcome, surveyed his noble province spread out before him and consecrated himself to his life work. In the bloom of manhood, having already done great things, he must have felt that the greatest were yet to come. The problem was still to be solved, hidden rocks might wreck him, but relying on his own fertile brain, the support of his coreligionists, and more than all upon the Divine aid which he had preached and experienced in the past he was ready to try the Holy Experiment. 


\section{THOMAS LLOYD}

The Lloyds of Dolobran in Montgomeryshire were an ancient and honorable family which claimed descent from the old princes of Wales. Thomas Lloyd was born February 17th, 1640. As were also his older brothers Charles and John he was educated at Jesus College, Oxford. Both Charles and Thomas joined the Society of Friends and, especially the former, suffered severely in person and estate on account of their fidelity to its principles.

These Welsh Friends took a certain un-Quaker-like pride that they were descendants of the old Britons, a proud and warlike people who had never been conquered. Yet George Fox with his preaching of peace and Divine communion and the simplicity and sincerity of life which flowed from it made a deep impression upon them. A minister of Denbighshire heard of him and sent two of his congregation "to trie the Quakers." Fox in his Journal tells the result: "When these triers came down among us the power of the Lord overcame them, and they were both of them convinced of the truth. So they stayed some time with us and then returned into Wales, where afterwards one of them departed from his convincement, but the other, whose name was John ap John, abode in the truth and received a gift in the ministry to which he continued faithful."

John ap John became the apostle of Quakerism in Wales. He aided in buying the Barony of William Penn, but he never came to America. He died at a great age, venerated as a patriarch of the flock.

Equally influential with him was Richard Davies. He 


\section{6}

met an itinerant preacher who had some influence with him, but his Quakerism seems to have arisen almost spontaneously. The thee and the thou, the refusal to doff the hat, to swear, and to make forcible resistance, the confident belief in direct teaching as a practical guide in all matters, the silent worship and the unconquerable sense of duty, sprang fully developed into being. He went to London to enter into business, but the need of his Welsh neighbors pressed on his heart. He tells the story of his courtship, preparatory to his migration: "So the Lord gave me a little time, and he alone provided an help-meet for me; for I prayed unto Him that she might be of His own providing, for it was not yet manifest to me where she was, or who she was. But one time, as I was at Horslydown meeting in Southark, I heard a woman Friend open her mouth, by way of testimony, against an evil ranting spirit, that did oppose Friends much in those days. It came to me from the Lord, that that woman was to be my wife, and to go with me to the country, and to be an help-meet for me. After meeting I drew somewhat near to her, but spoke nothing, nor took any acquaintance with her, nor did I know when or where I should see her again. I was very willing to let the Lord order it as it seemed best to Himself, and therein I was easy; and in time the Lord brought us acquainted with one another, and she confessed she had some sight of the same thing that I had seen concerning her. So after some time we parted, and I was freely resigned to the will of God; and when we came together again, I told her, if the Lord did order her to be my wife, she must come with me to a strange country, where there were no Friends but what God in time might call and gather to Himself. Upon a little consideration she said, if the Lord should order it so, she must go with her husband, though it were to the wilderness; and being somewhat sensible to the workings of God upon her spirit 
in this matter, she was willing to condescend in her mind to what He wrought in her; but by hearkening to one who had not well weighed the matter, she became disobedient to what God had revealed to her, which brought great sorrow and trouble upon her. I went to see her in this poor condition, and I rested satisfied with the will of God in this concern, being freely resigned, if the Lord had wrought the same thing in her, as was in me, to receive her as His gift to me; and after some time, we waiting upon the Lord together, she arose and declared before me, and the other Friend who had begot doubts and reasonings in her mind, that in the name and power of God she consented to be my wife, and to go along with me, whither the Lord should order us; and I said, in the fear of the Lord, I receive thee as the gift of God to me. So I rested satisfied with the will of God, for a farther accomplishment of it."

John ap John and Richard Davies were the apostles of Quakerism in Wales. Multitudes joined them and the usual persecutions followed. It was only necessary to offer them an oath of allegiance to insure a legal imprisonment and the ministers and magistrates were in harmony in their efforts to crush out the heresy. A priest offended by a failure to defeat Davies in argument had an oath tendered him and he spent years in jail.

Charles Lloyd, the chief man of the district, was reached by the power and fidelity of the Friends. Richard Davies tells the story: "There came in Charles Lloyd, of Dolobran, who was formerly in commission of the peace for Montgomeryshire, and had been in eleetion to be High Sheriff of that county, and also several of his well-meaning neighbors.

"The Lord was not wanting, but afforded unto us His good presence. Life and power came from Him, that reached the hearts and understandings of most of the people 
then present... The next morning we went to visit Charles Lloyd, of Dolobran, who tenderly received us, and several that were at the meeting came there that day, where we had a sweet, comfortable, refreshing time, in the presence of the Lord. ...

"The report of this meeting went through the country, some saying that most of that side of the county were turned Quikers.

"Whereupon divers were sent for, before Edward, Lord Herbert, Baron of Cherbury, to a place where he then lived, called Llyssin, about 3 miles from Dolobran.

"After some discourse with them, Lord Herbert sent them to Welshpool to prison, for refusing to take the oaths of allegiance and supremacy which they refused, because they could not swear at all, they being six sent together, viz., Charles Lloyd, Hugh David, Richard David, Cadwallader Edwards, Ann Lawrence, and Sarah Wilson."

Charles Lloyd was " put into a little smoky room and did lie upon a little straw," but his brother Thomas interceded for him and he was allowed to hire a prison for himself where the Friends went to hold meetings. This condition of semi-imprisonment lasted from 1662 till, ten years later, Charles II made his declaration of indulgence which opened many prison doors and Charles Lloyd was able to return to Dolobran. Thomas Lloyd was liberated at the same time. ${ }^{1}$

In 1660 the Lloyd brothers had a friendly public discussion with the Bishop of Asaph, turning principally on the necessity of water baptism. ${ }^{2}$

${ }^{1}$ In the Journal of George Whitehead printed in 1725 we find an interesting description of the efforts made to circulate this declaration of indulgence so that official information enuld reach all the prisons including certain remote districts of England and Wales.

2 The manuscript account of this discussion is now in the custody of the Historical Society of Pennsylvania. 
It was a temperate and courteous occasion. The Bishop saicl "He did not expect so much could be said by any on so little warning and that he did not expect so much civility among the Quakers." "He highly commended Thomas Lloyd "who had the chief part for the Friends, but the discussion made no converts to either side.

The toleration of Charles II. did not last long. Sometimes it was the refusal to swear, sometimes it was the wearing of the hat, sometimes attendance at meetings, that was the excuse, but back of it was the hope to check the preaching which was depopulating the old churches and introducing new customs in religion and society. There was the continual prospect of imprisonment, of distraint of goods, of civil disabilities, of popular opprobrium awaiting the conrerts. With such a home-loving people the trial must have been very sore indeed to induce them to consider expatriation.

There now opened a prospect which would rob this last remedy of some of its severity. William Penn had secured Pennsylvania as a haven of rest for Quakers, a New Wales, where they could retain their old language and customs and have free course for their new religion.

So a delegation of them including John ap John, Richard Davies and Charles Lloyd went up to London to see Penn. They asked for a "Barony" where they might preserve all that was dear to Welshmen, free from the intrusion of others, free in locil matters from governmental interference and of course free from molestation in matters of conscience.

There is unfortunately no writing to prove exactly what was promised, and probably never was. Penn wrote his Surveyor Thomas Holme that sufficient Welshmen were coming to occupy 40,000 acres and adds, "I do charge thee and strictly require thee to lay out said tract." As Hugh 
Roberts wrote him ten years later, "I can truly say that many of us had never come here but because of the love and unity and confidence we had in thee."

The tract was laid out. It began opposite Philadelphia and extended westward and northward along the Schuylkill River, the country now traversed by the main line of the Pennsylvania R. R., many of whose stations still perpetuate the Welsh names.

The stream of immigration began immediately and certain parts of Wales were almost depopulated. Large tracts of 5000 acres were bought by the more wealthy and divided among others. The whole of the 40,000 acres was not immediately taken however and this made trouble later. But within and around the original tract many Welshmen, Quakers and others found homes.

The leaders of the Quaker movement in Wales however did not eome. They bought land for their more impecunious brethren but their place was at home where their sufferings were beginning to conquer the spirit of persecution. They lived long enough to see the Toleration Act of William and Mary in 1691 grant them the right of affirmation instead of the oath and other liberties which made them reasonably secure from jailing, though many political and social disabilities still remained to trouble them.

The younger son, Thomas Lloyd, cast in his lot with the immigrants and became the leader not only of Welsh interests in Pennsylvania, but as well of the state and church in the colony. Thomas Lloyd landed in Philadelphia on 6th month (August) 20,1683. He was promptly seized upon both by the meeting and the state for important services.

In these early days it was difficult to separate the minister and the magistrate. The same men held official positions in ehurch and state. The Councilmen and Assemblymen were frequently preachers. The legislative meetings 
were opened by a period of silent devotion, and the religious meetings had to change their times of holding to suit the secular courts. All the functions of the Holy Experiment were religious and all the religious arrangements needed the aid of secular wisdom. It is convenient however in the narrative to separate the activities of Thomas Lloyd. In each case his strong qualities of leadership, and perhaps also some deference paid to rank when that rank won respect by the personality of the man, gave him immediate preeminence. No one could dispute this, except during that short time of about a year when the proprietor worked by his side. The Quaker would not remove his hat in the presence of priest or magistrate, protector or king, but he had to recognize ability and learning, and the qualities which gentle nurture and college training necessarily produced.

The first record we have of a meeting appointment was about two months after his arrival when he was made a member of a committee to repair the meeting house. Immediately following this he was appointed on another whose miscellaneous duties were to care for the poor, renovate the property, encourage Friends to attend meeting and raise money for general purposes. Then followed all sorts of duties, to write epistles to England, to adjust quarrels among citizens, to sign certificates of membership when a ship was about to sail for England. In practically every case his name was first mentioned on the committees, which either meant chairmanship or a recognition of superior fitness.

His most serious service as well as the most harassing for a sensitive man, for it meant the breaking of intimate friendships, was in connection with George Keith. The two scholars had been associated on many important labors in the church, and now they were to be the leaders in oppos- 
ing parties which shook Philadelphia Quakerism to its depths. Personalities were used unsparingly, at least on one side, and the matter was fought out to its bitter termination.

George Keith was born in Scotland about 1638 and educated as a Presbyterian. He studied at the University of Aberdeen, and received the degree of Master of Arts from that institution. Bishop Burnet says that he "was the most learned man ever in the Quaker sect, well versed both in Oriental tongues and in philosophy and mathematics." About 1663 or 1664 he joined the Friends, and for twentyseven years was in favor, sharing with the other leaders of the Society the full measure of writing, public discussion and persecution. He had the true spirit of the early Friends. He said in 1665:

"It lay upon me from the Lord to depart from these teachers who could not point me to the living knowledge of God where I could find it; and I came and heard men and women who were taught of God who pointed me to the true principle; and though some of them could not read a letter yet $I$ found them wiser than all the teachers I ever formerly had been under."

Many other of his testimonies are eloquent of the great peace and rapturous joy that came into his heart as the result of the Quaker teaching of God's direct communion with men and his own experience of it. He found "the gates of the heavenly paradise" opened in himself and came to have a great love for all mankind. It is unnecessary for our purpose to go over the details of his early life. His books and sufferings both betray the unflinching spirit of the early Quaker apostle. He had his full share of imprisonments and beatings, which he bore with humility. $\mathrm{He}$ was especially effective in public discussions and vigorously argued his new convictions before hostile audiences of 
Presbyterian divines. In 1670 he published his "Benefit, Advantage and Glory of Silent Meetings," a most sympathetic treatment of the subject written in Aberdeen prison. "There are immediate revelations now-a-days" is the emphatic point. In 1675 he debated in company with Robert Barclay the principles of his sect before the students of the University of Aberdeen. He joined with George Fox, William Penn, and Robert Barclay in a visit to Germany, and worked in great unity with them. In 1684 he came to New Jersey where as surveyor he laid out the division line between East and West Jersey. In 1689, at the opening of the Friends' Public School, he was made headmaster, but gave it up in a year, finding that his abilities needed freer scope than in a school of young boys. Up to this time no serious ripple of discontent with Friends or of Friends with him seems to have appeared.

There now began to come out in his sermons and discourses certain doctrinal views, which were looked upon with suspicion by many Friends and received with enthusiasm by others. He charged that Friends had in their preaching of the inward Christ neglected the outward. He asserted that ministers declared that they could be saved by the Christ within them "without anything else," and hence that they undervalued the historic Christ and the Scriptures.

These doctrinal questions were mingled with others of a more practical nature. He charged a general slackness in the administration of the Discipline. The magistrates were often ministers, and in their civil functions would arrest offenders by force but without loss of life or limb. This Keith declared to be inconsistent with the profession of nonresistance of evil.

In these early days the civil and ecclesiastical powers were so closely united in practice, if not in theory, that it 
was difficult to distinguish them, and disputes in one court were easily transferred to another.

There were doubtless, owing to the emphasis Friends placed on inspiration as the sole endowment for the ministry, a number of crude and narrow preachers among them. The doctrine of direct divine leading unto all truth was so simple and had such sanction from the leaders of the Society that it is not surprising that it constituted for many the one staple subject of discourse. A scholar like George Keith, whether in general harmony with them or not, could not fail to see the lack of perspective and breadth of such men. That there was no ground for his doctrinal charges would be difficult to maintain. That Friends denied the offices and failed to recognize the divinity of the Christ of Judea was in answer to his challenge emphatically contradicted by official assertions both in Pennsylvania and London. The Friends across the water sent a special message urging a full acceptance of the biblical account of Christ, while not weakening in the least in their belief that the light of Christ reached all men whether they had this account or not. The leading Philadelphians issued another paper defining their position in full in the same strain. It was urged upon Keith that the doctrinal shortcomings of individuals should not be used against the Society. It was also urged that for a score of years while the same conditions existed he had been a strong defender of its teachings.

It was quite as much the spirit as the doctrine of George Keith to which the Friends objected. He loved controversy, and in the days when he was in favor used the severe language of his time against the opponents of Quakerism. His open arguments with Cotton Mather and other New England divines left but little to choose between them as to the courtesies of debate. But to call the leaders of the Yearly Meeting by opprobrious names, to get excited and 
angry in discussion, and to make statements which he had to retract, were evidences of "brittleness" of temper, according to his opponents, which were inconsistent with a claim to spiritual guidance. He was evidently hot-tempered and pugnacious. He called Thomas Lloyd, then Deputy-Governor, and a man of amiable disposition and excellent abilities and education, "an impudent man and a pitiful governor," challenged Lloyd to send him to jail, and said that " his back had long itched to be whipped." A magistrate he called "an impudent rascal," and a meeting of ministers he said were "come together to cloak heresies and deceit, and that there were more damnable heresies and doctrines of devils among the Quakers than among any profession of Protestants."

It was an age of rough controversy. His opponents did not spare him. Possibly they better controlled their temper in debate, but in the title-page to one of their works written in cold blood a little later the author speaks of "... the apostate convicted ... in which his apostacy from the Truth and enmity against it is manifested, his Deceit Hypocricie and manifold prevarications are discovered, his false Quotations Lyes and Forgeries out of the Quakers Books are detected, etc."

and even the courteous Thomas Story calls him "that contentious apostate from the Truth of God once made known to him."

Matters could not abide in this state. Keith had complained to the Ministers' Meeting against William Stockdale, charging him with saying that Keith had preached two Christs. Stockdale denied the charge, and in reply said that Keith had called him "an ignorant heathen." The meeting blamed them both and tried to make peace. But it was too late. Thomas Lloyd and twenty-seven other ministers issued a temperate epistle presenting the troubles 
they had with Keith, earnestly appealing to him to be reconciled and to lay down the separate meeting which he was then engaged in setting up, and repudiating him as an authorized minister among Friends.

The ministry and the magistracy were so associated that Keith in one of his pampllets laid himself open to the charge of sedition and disturbance of the peace by reviling Samuel Jenings, who was as an ecclesiastic strongly opposed to Keith, and as a judge and magistrate the author of certain acts against privateers which Keith bitterly attacked. The Grand Jury brought in a true bill, and Keith and a friend were fined five pounds each, which fine was never collected. The Justices imposing this fine were all Friends and among Keith's strongest antagonists. They said in an explanation to the public that they would endure all personal reflections and attacks upon their religious body in quiet, but the pamphlets tended to revile state officials and incited to oppose the administration of justice.

These trials bring out the prominence of ministering Friends in civil positions, a prominence to which Keith and his friends with some justice objected, but which naturally resulted from the Friendly conception of the absence of any definite line of distinction between the preachers as a class, and the other spiritual members of the body.

"The Meeting of Ministering Friends" and in Seventh Month (September) 1692 the Yearly meeting itself were the ecclesiastical courts into whose hands George Keith now fell. The latter body after a careful investigation declared:

"We find it our duty to join with our brethren in their testimony against that spirit of reviling, railing, lying, slandering, and falsely accusing which hath risen and acted notoriously in George Keith and his adherents which hath led them into a mischievous and hurtful separation." 
This paper is signed by over 200 Friends beginning with Thomas Lloyd, including Pastorius and nearly all those prominent in ehurch and state.

Keith now became an avowed leader of a new sect, gathered out of the large body of Friends. He set up meetings in Philadelphia, Burlington, and Bucks County. His eloquence, learning, and previous high standing brought many to his ranks. The denial of the outward Christ was his main subject of attack. In these days he had among other public controversies one with James Diekinson, an English minister, in which, according to the account of Dickinson's eompanion, he was vanquished " and went away in great wrath." Such discussions and voluminous writings fanned the separating spirit.

It was said many times that Keith's doctrinal attacks upon the main body of Friends could be all answered by his own earlier writings, and after examining these one is inelined to think the statement true. He had often pleaded the sufficiency of the Divine Light to lead into doctrinal truth, into correct living, into right public preaching and praying; and it is impossible to note any difference between his views and those of his friend and fellow-worker and sufferer, Robert Barclay. The charges he now made against the Philadelphia Friends seemed to indicate a change in himself. The main one, that Friends considered the Light within sufficient, "without something else," was one to which his own early statements made him quite as fairly liable to attack as his opponents. But they both asserted in positive terms the ordinary orthodox position as to the outward Christ and the Scriptures. It seems impossible to reconcile the Keith of 1670 with the Keith of 1691 and later. Of course he had a perfect right to change his position as to these matters, but he never fairly admitted the change. 
In a public discussion Thomas Lloyd had said that one might be saved without the outer revelation of Christ if he had had no opportunity to know it. But Keith said that this was impossible, and that if such were Lloyd's views " he could not own him as a Christian brother, though he might be a devout heathen." This is hardly compatible with his earlier statement, "God himself . . . is objectively manifest so that he can be heard, seen, tasted, and felt if all Scripture words were out of our present remembrance," or with many other similar statements. In 1670 he had defended Friends against Robert Gordon, who made against them the same charges he was now preferring against the Philadelphians.

The controversy was now carried to London by Keith himself, where we may leave it with the statement that London Friends including William Penn disowned his spirit, and after a hot controversy he joined the Established Church, was ordained a minister, and later traveled through the colonies gathering recruits among his own followers and others into the fold.

His "Keithian Quakers" in Pennsylvania formed an opposition body, separate from the main organization of Friends, and always opposing their political leadership. The latter days of 'Thomas Lloyd were embittered by their attacks, but this only seemed to increase the loyalty of his friends. The Keithian party soon dwindled and disappeared but smouldering feelings of hostility did not entirely vanish for a decade or more.

Thomas Lloyd entered the lists unwillingly and only when he saw that no other authority but his could stay the tide. Hugh Roberts, a friend of William Penn, ${ }^{1}$ writing presumably in 1694 , tells the story with deep feeling but

1 Pennsylvania Magazine, Vol. 18, p. 205. 
evident fairness and his testimony is supported by all we know of the matter.

" my dear frd there another thing yt trubles me very mueh yt is in one of ye two epistles yt eam from ye two weekes meeting in London, if I doenot mistake they writ as if ye difrence or falling out was between ye two scolars and all ye rest but parties of both sides, if you judge so I tell thee you judge hard of all, and you are in a great mistake for I know to the contrary for Tho. Ll: was not concernd a long time after he broke out and I know he did endevour a prswayd both frds and to gain upon him as much as any man amongst us, and for a long tim ye difrence did not at all apear between Tho Ll and he, but at last when he could not be pervaild upon but he rund frds down at straint rate becaus they refused to subseribe his ereed with many other things of his (illegible) which frds could not joyn withall, it is true Tho. Ll. was fored to apear, but as soon as he apeard though very meeke Loving and tender he began to be mor eger at him than any, for he thought if he could but run him down he could deal well inufe with the rest, and after this it is true Tho was forced to stand in ye front, being beter quarif (torn) amongst us, this I do believe yt ther is not a man amongst us yt ean truley lay to his charg not as much as a hasty word or unsavry word in all ye discours yt he had with him from first to Last but always eald him his ffrd G. K. but I have heard many a time $\mathrm{G} K$ abusing him calling him a poe a hyppocrit an impudent man with abundance of such unsavrey expressions."

The controversy was certainly something more, as Hugh Roberts indieated, than a theological contest between two seholars equally virulent and ambitious for leadership.

On the same boat with Lloyd eame Francis Daniel Pastorius, the pioneer of the great German emigration to Pennsylvania. Pastorius could not then speak English, nor Lloyd German but he had been educated at Oxford and so had the continental pronunciation of Latin. 
"Alone with him I could in Latin then commune, Which tongue he did pronounce right in our German way."

For William Penn Pastorius had an unbounded admiration which he expressed in many ways. "My pen," he says, "is too weak to express the lofty virtues of this Christian, for such he is indeed." This esteem lasted through all their difficulties about the assignment of land and through Penn's troubles in England. The proprietor cordially returned the appreciation. When in the country he regularly met Pastorius in a social way, and in reply to his father in Germany gave a most affectionate tribute in Latin to the virtue of the distinguished son. Pastorius could not resist the temptation to drop into verse at every suitable opportunity and when Penn reached his colony a second time in $\mathbf{1 6 9 9}$ he was met by a long and most appreciative metrical welcome.

But scarcely second to Penn, Pastorius loved Thomas Lloyd. The two scholars had common knowledge, common mystical ideas, and common interests in the colony. They were both strongly opposed to George Keith and worked side by side in many church affairs. In fact Pastorius tells

"We never disagreed nor were at variance

Because God's sacred Truth (whereat we both did aim) To his endeared friends is every where the same.

Therefore 'twas he that made my passage short at sea, 'Twas he and William Penn that caused me to stay

In this then uncouth land and howling wilderness

Wherein I saw that I but little should possess.

And if I would return to my father's house

Perhaps great riches and preferments might espouse."

Whittier tells us

"With lettered Lloyd on pleasant morns he strayed

Where Sommerhausen over vales of shade

Looked miles away, by every flower delayed, 
Or song of bird, happy and free with one

Who loved like him to let his memory run

Over old fields of learning and to sun

Himself in Plato's wise philosophies

And dream with Philo over mysteries

Whereof the dreamer never finds the keys."

Pastorius' sympathy with Lloyd extended to his daughters, whose acquaintance he also made on the boat, and long after when they were wives and mothers he wrote them a long poem, from which the preceding extracts are taken, ending with lines:

"Thus I am finishing my homely lines and crave

Dear shipmates, your excuse that I so boldly have

With doggrels troubled you. Farewell, remembering me

Who am your loving and affectionate F. D. P."

At the risk of forgetting that this is a biography of Lloyd rather than of Pastorius it is interesting to note the relation of the German scholar to other Friends, while he served as teacher in the Friends Public School.

On 10 mo. 31st, 1697 Samuel Carpenter and James Fox were authorized by the Monthly Meeting of Philadelphia "to treat with Daniel Pastorius and Thomas Makins" and a month later they are authorized to engage them at forty pounds each yearly. The school was to open on the first of first month (March), 1698 "over the meeting house." There Pastorius remained two years. Phineas Pemberton was then clerk of the Yearly Meeting and an important patron of the school. He writes Pastorius shortly after the school opened apologizing for the lateness of "My little girles" in reaching school on account of illness at home, to which Pastorius replies in a courteous letter. Phineas' son Israel did not however fare so well. Two months later the boy makes this record: 
"About the 10th day of the 4th month 1698 Francis Daniel Pastorius a German one of the school masters at Philadelphia, took occation (upon a small difference that did arise between me and another scholar) to beate me very much with a thick stick upon my head untill the blood came out and also on my arms untill the blood started through the skin, and both were so swelled that the swelling was to be seen so that it caused my clothes to stand out and the flesh was bruised that it turned black and yellow and green. My father coming to town on the 13th day of the 5th month and my sister acquainting him how I had been used took me away from the school . . . and sent me into the country from which I writ the following epistles."

One of "the following epistles" was written to the other master, Thomas Makin, and was a warm expression of liking for him and a different feeling for "another" who always gave him " rough answers."

Thomas Makin naturally felt that the withdrawal would affect the reputation of the school and wrote the father that he would give Israel studies under other masters than Pastorius and the appeal seems to have been successful.

The German schoolmaster was evidently choleric and thoroughly believed in the rod. We may if we choose reconcile this with his conduct as a magistrate as given in the Pennsylvania Pilgrim.

"Whatever legal maze he wandered through, He kept the Sermon on the Mount in view, And justice always into mercy grew.

No whipping post he needed, stocks nor jail, Nor ducking stool; the orchard thief grew pale At the rebuke, the vixen ceased to rail."

But schoolboys needed other discipline than common culprits, or perhaps Whittier had not read these Pemberton letters. ${ }^{1}$

${ }^{1}$ Now in the Library of the Historical Sooiety of Pennsylvania. 
The Yearly Meeting directed that Pastorius "Primmer" should be printed at the expense of Friends. Only one copy of this book, at Birmingham, England, is known to be in existence.

Thomas Lloyd's services were demanded by the state with equal promptitude after his landing. On the 25th day of the 8 mo. 1683 he was made foreman of a Grand Jury in a case of counterfeit money. Two months later he was made "Master of the Rolls," and in the following spring a member of the Governor's Council.

The legislative body was at this time composed of Council and Assembly. The Council originated all laws which to be valid must be confirmed by the elective Assembly. It was also the executive body of the colony and hence was clothed with great powers. The right to originate laws was soon taken from it by the growth of the democratic sentiment in the province and after 1701 it was completely shorn of legislative power, and became simply an advisory board, appointed by the Governor. A seat in it was however always an honor, and the list of provincial councillors contains the names of nearly all the prominent men of the colony.

After William Penn's return to England in 1684, Thomas Lloyd was made President of the Council, and hence the chief officer of the province till 1688. In February of this year Penn appointed five Councilmen as his Deputy: Thomas Lloyd, Robert Turner, Arthur Cook, John Symcock and John Eckley. This arrangement lasted till December 1688 when as Lloyd had refused further service Captain John Blackwell, an old Cromwellian soldier, not a Friend, reached Philadelphia under appointment of William Penn to act as Deputy-Governor, and then trouble began. Lloyd had also been made keeper of the Broad Seal, 


\section{4}

POLITICAL LEADERS OF PENNSYLVANIA

without the imprint of which no act of the government would be valid. Not approving of certain commissions he refused to affix it to them and in this position he was sustained by a minority of the Council. It is impossible not to see the sectarian lines which were gradually being drawn, the Friends of prominence generally siding with Lloyd. The minutes of the Council declared that Lloyd's friends had "an inordinate affection" for him. When John Symcock at the next meeting objected to the adjective the Governor insisted that it stand on the records. A Councillor lamenting their inability to do business declared that they had two Governors, one inside the Council and one (Thomas Lloyd) outside.

Lloyd had been returned as a member from Bucks County, but having committed certain stretches of authority of doubtful legality, he was charged by the Governor with high crimes and misdemeanors and his right to a seat refused pending the trial. Another elected member, Samuel Richarison, was also refused for having spoken slightingly of the Governor, though he made the vigorous remonstrance, "I will not withdraw. I was not brought hither by thee and I will not go out by thy order. I was sent by the people and thou hast no power to put me out." John Eckley was also denied the right to sit for reasons which will appear later. Other of the members objected to these acts of arbitrary power, and the sessions of the Council were taken up by frequent disputes as to their propriety, and but little real business was transacted.

The Welsh Tract was one of the subjects of difficulty. It had been supposed to be all in Philadelphia County. But in 1688 Caleb Pusey and certain other reputable citizens of Chester County made a request that part of it should be transferred to that County because their numbers were small and the charges of maintenance burdensome. This 
request was fortified by depositions that William Penn had stated that such a division should be made, and by some maps which supported it. Lloyd, though denied membership in the Council, was allowed to appear on behalf of his countrymen, but all he could do was to ask for more time to carry the matter to England that the justice of the measure might be more fully considered. Blackwell had with him the majority of the Council and the minority were willing to concede the reasonableness in a general way of the proposition. The act was passed and Merion was placed on one side of the line and Haverford and Radnor on the other, and so they have remained to this day.

The Welsh felt deeply aggrieved. Their Barony, already shorn of certain powers which they expected to retain, was now divided between two counties. At first they refused to abide by the decision and the men from Haverford and Radnor joined with the Merion voters in sending John Eckley to the Council, but as already stated he was refused admission.

The future history of the Welsh Tract is interesting. One can not but sympathize with the gradual fading away of the hopes for an old Wales in the new country.

They had not taken up their whole tract, and in $\mathbf{1 6 9 0}$ men of other nationalities came in with claims. The settlers made an eloquent appeal: "We, the Inhabitants of the Welsh Tract in the Province of Pennsylvania in America, being descended of the ancient Britons, who always in the Land of our Nativity, under the Crown of England, have enjoyed that Liberty and privilege as to have our bounds and limits by ourselves within which all causes, quarrels, crimes, and titles were tryed, and wholly determined by officers, magistrates, and jurors of our own language, which were our equals; having our faces towards these counties, made motion to our Governor, that we might 
enjoy the same here, - to the Intent we might live together here, and enjoy our liberty and Devotion; which thing was soon granted us before we came into these parts."

It was deeided that if the Welshmen would pay all quitrents since 1684 they might preserve their tract intact. They refused the proposition, but expressed a willingness to be responsible for the whole 40,000 acres in future. This was declined. When it was too late they reconsidered the matter and agreed to accept the conditions. But the commissions to others had already been executed. Their political integrity had been broken, and now their social comradeship was threatened. The Barony was about to pass away, but the "Great Welsh Tract" beeame a well marked section of the province, leading in enterprise and prosperity, up to the time of the Revolution.

The Friends' meetings were more considerate of Welsh sentiment than the state authorities. The Quarterly Meeting of Chester, in 1700, sent word to the Haverford Friends that as they were in their county they should be joined to their meeting. But Haverford protested, and the Philadelphia Meeting strongly supported them: "Whereas Haverford Meeting hath belonged to this Quarterly Meeting from the first settlement and for several other reasons this meeting unanimously desire that the Monthly Meeting at Haverford may not be separated from this our Quarterly Meeting"; and so it has remained to this day.

The separateness of the Welsh settlers now rapidly departed. Business, marriages, politics drew them into close association with the English, and while their brethren in the old country retained their language, the new country Welshmen, who had so pathetically appealed for national peculiarity, had hefore the Revolution lost it all.

While Iloyd had failed in the matter of the Welsh settlement he had proved a strong political antagonist. After 
his death Haverford Monthly Meeting spoke of "his meek and lamb-like spirit, great patience, temperance and humility and slowness to wrath." William Markham however, who took sides with Blackwell and kept the minutes of the Council, gives a little insight into the turbulent politics of the time.

"The Govr declared ye Council to be adjourned till ye next council day, viz: to ye fifth day of ye same week, at nine of ye Clock, at ye same place; and Rose up out of his place to depart accordingly; upon wch severall of ye members of ye Couneill departed. But divers remayned and a great deale of confused noise and elamor was Expressed at and without the doore of ye Govrs roome, where ye Councill had sate, wch oceasioned persons (passing by in the streets) to stand still to heare, which ye Govr observing, desired ye sayd The Lloyd would forbeare such lowd talking, telling him he must not suffer such doings, but would take a Course to Suppress it, and shutt ye Doore. So he went away, attended with severall of ye members of ye Couneill, others staying behind with ye Governor."

Other scenes were equally boisterous. One ean not but feel as he reads the personnel of those who voted against Lloyd in the Council that the political differences of the Blackwell era had something to do with the Keith controversy which followed.

Penn tried to make peace. On 7 mo. 25th 1689 he wrote to Blackwell, "I would be as little vigorous as possible, and do desire thee by all the obligations I and my present eircumstanees can have upon thee to desist the prosecution of T. L. I entirely know the person both in his weakness and accomplishment \& would ye end the dispute between you two upon my single request and command and that former inconveniences be rather mended than punished. Salute me to the people in general \& pray send for $J$. Simcock, A. Cook, Joln Eckley and Samuel Carpenter \& 
let them dispose T. L. and Sa Richardson to that complying temper that may tend to that loving and serious accord yt becomes such a government."

But Penn from England finally recalled Blackwell. In his farewell address the Deputy used words the sincerity of which we can hardly doubt. "'Tis a good day. I have given and I do unfeignedly give God thanks for it, for to say no worse I was very unequally yoked." He was probably an honest but tactless man who did not understand the Quaker character, and pugnaciously attempted to override it. Thomas Lloyd had undoubtedly proven an "unequal " yoke fellow.

Penn now made two propositions: One was to have three names sent to him by vote of the Council, one of whom he would appoint as Deputy-Governor. The other was to allow the Council itself to be Deputy-Governor and elect its own President. The Council unanimously chose the latter and elected Thomas Lloyd President. In this form the arrangement continued till 1693, when Penn was deprived of his government by the King, and the province placed in the hands of Benjamin Fletcher, Governor of New York. This period of about four years from 1689 to 1693 was quiet and uneventful, as shown in the Colonial Records though there is a gap of over two years in the minutes. The political peace speaks for the wisdom of Lloyd's administration and its general acceptance by the province.

When Fletcher came on April 26, 1693 his first act was the following: "His excellency having sent for Thomas Lloyd, the late Deputy-Governor did offer unto him the first place in the Council which he did refuse." This example was followed by other Friends.

When early in 1695 the province was restored to William Penn as Proprietor and Governor, Thomas Lloyd was no more. He died at the age of 54 . 
For a man of quiet instincts his life had been a troubled one. Persecuted in Wales, he sought the peace of a Quaker province. Immediately he was thrown into the distractions of a government of non-experts, jealous of their liberties, suspicious of every move that threatened to curtail them, uncertain of their powers and crude in their methods. $\mathrm{He}$ could suffer passively in Wales under unjust laws and their unkindly enforcement. But he could not see lost the liberties which William Penn and his friends had purchased in Pennsylvania, when the responsibility for their defense rested partly upon him. By common consent the strongest man in the province, positions of influence were almost forced upon him. He resisted when he could. William Penn writes in 1687, "I am sorry that Thomas Lloyd, my esteemed friend, covets a quietus, that is young and active and ingenious, for from such it is that I expect help, and such will not sow, I hope, in vain." And the next year he urges him "By all that is reverent, tender and friendly I beseech thy care, condescension and help for that poor province." Lloyd lived in the province about eleven years during seven of which he was at the head of the government.

Such appeals could not be denied, and so he fought through the Blackwell régime and the Keith controversy as best he could, keeping the esteem of the best men of the province, but suffering, no one knows how much, from the bitter attacks upon him. Lover of peace as he was there is no evidence that he allowed these attacks to divert him from his path of duty. Scholar and mystic by temperament and training, he became a politician by force of circumstances. In happier times his religion and his learning would have been his cherished objects, but his province and his sect owe to him a debt in that he sacrificed fortune and the life of lettered ease and spiritual quiet to the stern demands of political and ecclesiastical battle. 
His loving Welsh friends of Haverford Monthly Meeting leave this memorial of him.

"The love of God, and the regard we have to the blessed truth, constrains us to give forth this testimony concerning our dear friend Thomas Lloyd, many of us having had long acquaintance with him both in Wales, where he formerly lived, and also in Pennsylvania, where he finished his course, and laid down his head in peace with the Lord, and is at rest and joy with Him for evermore. He was by birth of them who are called the gentry, his father being a man of a considerable estate, and of great esteem in his time, of an antient house and estate called Dolobran, in Montgomeryshire in Wales. He was brought up at the most noted schools, and from thence went to one of the Universities, and because of his superior natural and acquired parts, many of account in the world had an eye of regard towards him. Being offered degrees and places of preferments, he refused them all; the Lord beginning his work in him, and causing a measure of his light to shine out of darkness in his heart, which gave him a sight of the vain forms, customs, and traditions of the schools and colleges. And hearing of a poor despised people called Quakers, he went to hear them, and the Lord's power reached unto him, and eame over him to the humbling and bowing his heart and spirit; so that he was convinced of God's everlasting truth, and received it in the love of it, and was made willing, like meek Moses, to choose rather to suffer affliction with the people of the Lord, than the honours, preferments, and riches of this world. The earthly wisdom came to be of no reputation with him, but he became a fool, both to it and his former associates; and through self-denial and taking up the daily cross of Christ Jesus, which crucified his natural will, affections, pleasures, he came to be a scholar in Christ's school, and to learn the true wisdom which is from above.

"Thus, he departing from the vanities and iniquities of the world, and following the leadings, guidance, and instructions of the divine light, grace, and spirit of Christ, came more and more to have an understanding in the mysteries of God's kingdom, and was made an able minister of the everlasting gospel of peace and salvation, his acquired parts being sanctified to the service of truth. 
"His sound and effectual ministry, his godly conversation, meek and lamb-like spirit, great patience, temperance, and humility, and slowness to wrath; his love to the brethren, his godly care in the Cliurel of Christ that all things might be kept sweet, savoury, and in good order; his helping hand to the weak, and gentle admonitions, we are fully satisfied have a seal and witness in the hearts of all faithful Friends who knew him, both in the land of his nativity and in these American parts. We may, in trutll, say he sought not himself, nor the riches of this world, but his eye was to that which is everlasting, being given up to spend and be spent for the truth and the sake of Friends. $\therefore$ He was taken with a malignant fever the 5 th of the 7 th month, 1694 , and though his bodily pain was great he bore it with much patience. Not long before his departure some friends being with him he silid, "Friends, I love you all, I am going from you, and I clie in unity and love with all faithful Friends. I have fought a good fight and kept the faith, which stands not in the wisdom of words but in the power of God: I have sought not for strife and contention, but for the grace of our Lord Jesus Christ, and the simplicity of the gospel. I lay down my head in peace, and desire you all may do so. 'Friends, farewell.'

"On the 19th day of the 7th month aforesaid, being the 6th day of the siekness, it pleased the Lord to remove him from the many trials, temptations, sorrows, and troubles of this world, to the kingdom of everlasting joy and peace; but the remembrance of his innocent life and meek spirit lives with us, and his memorial if. and will remain to be, sweet and comfortable to the faithful. He was buried in the Friends' burying-ground in Philadelphia, aged about fifty-four years, having been several years President and Deputy-Governor of Pennsylvania."

The following letter gives some insight into the conditions in the colony and the charaeter of Thomas Lloyd.

"From Thomas Lloyd to his Friends, belonging to Dolobran Quarterly-Meeting, Wales." 1

1 The original of this letter is in the Roberts Collection of Haverford College. 
"Philada. 2d of ye 9thmo 1684.

"My Dear and Well beloved Friends, of, and belonging to Dolobran Q. Meeting,

"The warm and tender salutation of My love is unfeignedly to you, with whom I have convers'd and walked some years, in unity, Zeal, Concord and Endeavor'd Service; you are, because of our nearness, familiar, yet Honourable, in my Thoughts and Esteem; The Truth, ' as it is in Jesus,' Prosper and encrease Dayly in your minds; and rest Bountifully upon your Habitations;

"It is no New Thing for you to Suffer Joyfully in your Persons and Goods; - The Lord gave us strength, Courage, Satisfaction and Honour Thereby; - Whil'st $\mathrm{He}$ is before our eyes, $\&$ his Holy fear in our hearts, Whether in Bonds or free, - in that or this Part of the world; - our Preservation we shall witness;

"Our Meetings are very full; I guess we had no less Numbers, last first-Day, than Eight Hundred, we are glad to see the faces of servicable Friends here, who Come in God's freedom; who are Persons of a Good Understanding \& Conversation; \& will Discharge their Stations Religiously; Such, Will be a Blessing to the Province; -

"The favourable Revolution of Providence hath founded the Government so here, That a man is at Liberty to Serve his Maker without Contempt, Discouragement, or restraint; Truth indeed Makes Men Honourable, not only here, but in most Places at least; But here Truth Receives Good Entertainment at first;

"Our Governor is just Embarking for England, our best wishes go with and attend him; He hopes to have an oportunity, by Testimony or Writing, to Express his Love and Remembrance to ye Several Churches of Brittain; - Our friends from the neighborhood are generally well, and Tolerably settled; Tho. Ellis, I. Humphrey, H. Roberts, J. Eckley, D. Davis and Many more are usefull and accepted among'st us; - 
"In Love I lived with you; In Love I took my leave of you; - and in Love, I now bid you, a Christian \& Brotherly Farewell; from your friend and Brother,

Thomas Lloyd;" 


\section{DAVID LLOYD}

DAvid Lloyd was born in Montgomeryshire, Wales, in 1656. Thomas Lloyd speaks of him in a letter as "my kinsman," though the relationship was probably not near.

Comparatively little is known of his early history. In some way he secured an accurate and available knowledge of law. His first wife was from Gloucestershire, and it is not improbable that he was educated in England.

In the seething political and religious times of the Commonwealth and later he imbibed the strong republicanism with which his name and talents were afterwards so conspicuously associated. Then he joined the Society of Friends, as many of the Commonwealth sympathizers did, and abjured fighting with material weapons forever. His pugnacity was, however, transferred to another field, and when in 1686 Penn commissioned him as Attorney-General of his new province he little knew what a determined opponent he was sending over the seas. On "the 5th of ye 6th Mo. 1686 " he presented his commission to the Council, subscribed to the necessary declarations of fidelity to the King and Governor and entered upon the duties of his office. From this time until his death, in 1731 , he was a potent factor, possibly as potent as any, considering permanent results, in the public affairs of the province. ${ }^{1}$

1 Macaulay in his History makes one David Lloyd an emissary in attempting the restoration of James II in 1690-91. The name was includer with that of William Penn and a number of noblemen and gentlemen in a list of supposed conepirators against William and Mary. It is possible that our David Lloyd went over from Pennsylyania for this purpose, though it seems improhable. Deborah Logan, however, speaks of him as the same person. She also says that he was Captam in the "Republican Army," presumably 
Two months later Patrick Robinson, who appears to have been a testy and obstinate official, was discharged from his position as Clerk of the Provincial Court, and David Lloyd was appointed to the place. He was also made clerk or deputy to the Master of the Rolls, Thomas Lloyd.

As Attorney-General there is only one important case with which David Lloyd was associated that has come down to us - the case in which William Bradford, the only printer of Philadelphia, was charged with issuing a seditious libel in connection with the George Keith controversy. Lloyd represented the prosecution, and won. Bradford was fined, but in the easy-going times the fine was never collected. It is important as being the first case where the seditious character of the publication, as well as the fact of printing, was submitted to the jury, and was thus important in establishing the freedom of the press. ${ }^{1}$

In the snarl that followed the appointment of Blackwell as Deputy-Governor, he showed the militant disposition which made his life a continual turmoil.

There came up in a meeting of the Council the question of a criminal whose case had been adjudged by the court of the county of Sussex, and the judgment reversed by the Provincial Court. The copies of the records of the higher court being conflicting, David Lloyd was asked to produce the original. He refused, saying that the Council had no authority to give such an order. Then, the minutes state, "he was thereupon ordered to withdraw. This was judged a high contempt in the said David Lloyd, and for that and other unseemingly and slighting expressions of his to the Governor and Council," he was discharged from his various positions. Thomas Lloyd then came to his rescue by issu-

that of Cromwell. As he was only two years old when Cromwell died, she was undoubtodly mistaken.

${ }^{1}$ See Pennypacker's Colonial Cases. 
ing a commission to him re-appointing him. This Blackwell conceded he had a right to do as his deputy, but not as elerk of the court. Blackwell was probably right, and the Lloyds had to recede from their position. David Lloyd finally gave up the papers in question, and ultimately recovered his standing.

In 1693 he was again brought unfavorably before the Council. One Charles Butler was charged with passing counterfeit coin. The jury found him guilty, and he claimed that David Lloyd added to their verdict that it was misprision of treason, which would cause a forfeiture of all the prisoner's property. In reply Lloyd claimed that his act was only a legal form. The Council concluded that it was not a proper case for it to decide, but gave an opinion that it did not look right to them to give so severe a penalty for so slight an offense and that there was " a matter of law in it against David Lloyd."

Another instance of a legal character may be eited to illustrate his facility in making enemies by the method of his proceedings. Francis Daniel Pastorius was the agent of the Frankford Company which owned a large amount of land in and around Germantown. He was dismissed from his position without proper compensation for past services. An adventurer now appeared, one Henry Sprogel, whom Pastorius calls " a cunning and fraudulent fellow," who had come over with the claim that he had bought in Germany the rights of several of the owners, and was proceeding to eject the innocent settlers by court decree. In company with a colleague, he retained David Lloyd, and gave to him as a fee 1,000 acres of land to which the title was doubtful. Acting on Lloyd's advice, he also bought up the whole bar of the province, consisting of three other lawyers, and sprung the case upon the court, which decided in his favor without a full hearing of the other side. 
The above is Pastorius's account, and in concluding it he gives this verdict: -

"If David Lloyd does justify this barbarous manner of proceeding and spoiling of widows and orphans, it's more than any can do that professes truth, and unless he really repent and endeavors to have restitution made to those who so deeply suffer, he certainly will be accountable for it at the great day of judgment." 1

In other letters Pastorius is even more severe, referring to him as d-1l. Finally he made his complaint to Philadelphia Monthly Meeting, where David Lloyd was a member. At the same time a request came from Lloyd to transfer his certificate to Chester Monthly Meeting. The double question was considered from month to month for six months with additions to the membership of the committee. Finally, on 9 month 27th 1713 the meeting minuted "However, it seems to the meeting to be that which is not of good report and therefore desires David Lloyd that he may forbear to have anything further to do towards strengthening the parties concerned therein." With this Scotch verdict the matter was left.

In forming a judgment of David Lloyd from these questions of legal ethics it is fair to bear in mind that he has placed on record no defenses of his action. He used the means which as a lawyer were at his command, and which many good lawyers at the present day sanction and adopt. The accounts of the transactions all come from his political and factional opponents. His skill and ability are abundantly manifest by the results, while his methods would doubtless be differently judged were we to hear his own statements. He, apparently, both in meeting his legal and political enemies, had no thought of protecting himself in history. The voluminous writings of Logan and Pastorius

${ }^{1}$ See M. D. Learned's Pastorius, p. 15.4. 
bear evidence of the opinion held of him by those whose plans he had opposed. That during all his life time he had an ardent political following, containing many good men, and more often than not defeated the opposition, are facts we know from the public records, but not from his pen.

To the political side of his life we now turn.

It was as a politician rather than as a lawyer that he will ultimately be judged, and here we find most opposite views of his character and influence. With some he is the great champion of democracy and popular rights against the encroachments of the Proprietary and his friends; with others he is simply an artful demagogue, using his great legal training and undoubted abilities to carry out his plans, ofttimes by unserupulous means, in the midst of a simple and trustful community of country Friends, of whose principles he was, or seemed to be, an ardent exponent. We will try to state the facts fairly before forming a judgment.

After holding various minor offices as clerk of the courts and of the Assembly, and deputy to certain officials, he was in 1693, at the time of the Fletcher régime, when William Penn was deprived of his government, elected to the Assembly. A year later he was made Speaker. Fletcher was opposed by the whole Quaker body in publie life and Lloyd had a united party with him. The Governor was attempting to break down the Penn authority and constitution, and as Friends had refused to sit in his Council, and as this body had the sole power of originating laws, he had at the start things pretty much his own way. But when these laws were presented to the Assembly, without whose sanction they could not be enacted, came Lloyd's chance. Every piece of legislation in conflict with popular rights was held up, and, after the fashion of the English Commons, supplies were denied pending the Governor's surrender. Lloyd was then as always very direct and open in his 
statements. On one of the occasions when a committee of the Assembly waited on the Governor to explain their non-passage of the supply bill, and various eircumlocutory statements were made, David Lloyd brought the matter to a head by the unmistakable announcement, "To be plain with the Governor here is the Monie Bill, and the House will not pass it until they know what is become of the other bills sent up."

The first contest was over the validity of the charter and laws granted by Penn. Fletcher elaimed that they were superseded by his royal commission. After some sparring, the Assembly had to yield. Then an appropriation was asked to defend the frontier of New York against the French, with whom England was at war. This demand struck at the anti-martial principles of Friends, and was successfully resisted, or rather postponed by the Assembly. The plan of delaying supplies till certain laws were granted was now tried in Pennsyivania, and, as in other colonies and in England, was successful in extorting one popular liberty after another.

Fletcher's rule only lasted about two years, when the government was restored to Penn, who made his cousin Markham his Deputy. Markham tried to live up to the arbitrary standard of Fletcher, but now both Council and Assembly opposed him. Lloyd was now in the former body, but remained the champion of democracy. One privilege after another was gained, giving the Assembly as well as the Council the right to originate laws, and allowing it to sit on its own adjournments. All and more than Penn had granted was secured. This condition lasted till 1699, when Penn, with his secretary, James Logan, came into the country, and David Lloyd's easy supremacy was over.

For he and Logan became bitter enemies. During Penn's stay of two years this did not much show itself, but he and 
his friends had so indoctrinated the colony with ideas of frecdom that Penn, half reluctantly, was forced to give a new charter, that of 1701, which lasted just seventy-five years, till abrogated in the opening days of the Revolutionary War. This abolished the Council as a part of the lawmaking power, making it only an advisory body to the Deputy-Governor, and granted full powers to the Assembly, with the Governor's assent, to pass all laws.

Hitherto Lloyd had seemed to be on good terms with Penn, whose commission he had held. But when the Proprictary sailed for England, leaving Logan his secretary and agent, a controversy, both personal and political, which in time became very bitter, arose between the Welshman and the Irishman. Both had a sort of fearless pugnacity which induced plain speaking without any avoidance of direct issues. Though their state papers are couched in terms of studied courtesy, there was no pains to conceal the differences involved between them.

Each had his party behind him. The most of the best educated city Friends, who were also friends of the Proprietary, were gathered in the ranks with the secretary. The country Friends, the great bulk of the population, concerned for their property and personal rights, followed loyally the skilful and forceful leadership of David Lloyd.

A small third party must not be neglected, the Churchmen, whose leader was Robert Quarry, Judge of the Admiralty, appointed by the Crown and independent of the Penn government. This party was troublesome more because it spread in England reports of inefficiency in the province, due, as it claimed, to Quaker scruples as to war and oaths, than as the result of its direct influence upon popular opinion.

David Lloyd was a strong uncompromising champion of Friends' views on these subjects and one of his favorite 
sharges against the Penn and Logan party was that relief in these matters was not granted, so that Friends could have their full share in government without any sacrifice of principle.

That Logan did not hold the Friendly attitude as to wars and self-defense is unquestionably true, and became more maniiest as he grew older. The Friends that surrounded him, however, did, - some of them quite as strenuously as did the countrymen, and perhaps with a better appreciation of all the factors entering into the matter. Hence on occasions they would rote money "for the Queen's use " on the general plea that the use the Queen made of it wits, as Isaac Norris expressed it, "Not our part, but hers."

Lloyd never compromised. When the Assemblies of which he was the Speaker voted moner, they made it a condition that "it should not be dipt in blood," and appointed trustees to hold it till they found how it was to be applied. $\mathrm{He}$ was willing to carry non-resistance to its fullest conclusion, and abruptly closed the question and adjourned the Assembly when it was found that the Deputy was not inclined to accept the grant on such dubious terms. In this particular he was undoubtedly supported by the great body of Friends in the province.

The close identity of Friends with the government is shown by two addresses passed by the House on the same day (May 25th, 1704) and both signed by Darid Lloyd, Speaker. One of these was "The Humble Address of the Freemen of Pennsylvania," congratulating "Our Gracious Queen Anne" on her accession. The other was "The Humble Address of the People called Quakers convened in Assembly," also addressed to "Our Gracious Qucen Anne," asking relief in the matter of oaths, which was approved by the Assembly, N. C. D. The Assembly, probably all Friends, adopted by the same vote and placed on its min- 
utes the two addresses, in one case as the Freemen of Pennsylvania and the other as the People called Quakers.

The severity of this controversy lasted from 1701, when Penn left the province, to 1710 , when Lloyd was completely, though temporarily, unhorsed. It was a sad decade for Quaker government. It is a mistake to assume, however, that the difference was as pervasive in the ranks as it was acrid among the leaders. The Province continued to prosper, immigrants came in, houses were built, farms were laid out and woods cleared, and the foundations of many a fortune and many a happy home were laid. A generation of Quaker politicians was being reared who were learning the meaning of self-government and democracy. History dealing only with men who ruled in Council and Assembly records the serious contests over what seem sometimes small matters, but the great body of Friends attended their quiet meetings in simple harmony and satisfaction with their lot. David Lloyd seems to have expected that a separation in meeting might result from the political conditions, but fortunately his prediction was not fulfilled. James Logan speaks of him as "a discordant in the Friends' meetings for business, so much so he expects a separation and purging; the young push for rash measures, the old for Penn's interests."

One of the questions of the day was the right of the Assembly to come together and adjourn at its pleasure. In view of the history of England under the Stuarts, now not so very far in the background, it is not a matter of wonder that they were sensitive on this point. William Penn had granted in his charter of 1701 the right of the popular house, to be, with the assent of the Governor, the whole legislative body of the Province, to be elected on the 1st of October every year without any call from the Governor and to sit on the 14th following. The only question remaining was 
as to its right to adjourn to some fixed date within the year of its service.

When in $\mathbf{1 7 0 2}$ there was difficulty in organizing an Assembly owing to the discordant politics of the Province and Territories (Pennsylvania and Delaware) which had hitherto worked together as one Colony, but were now about separating, it was suggested that the Governor might adjourn the meeting to a future day. Immediately David Lloyd sounded the alarm. Though it was only a preliminary conference, and not an Assembly, the account states: "David Lloyd objected to the word adjourn, for the Charter empowering them to sit on their own adjournments, they would betray their trust should they admit of any other adjournment." His keen eye for the establishment of a precedent which would in any degree threaten popular rights seized upon this little point for protest.

The Governor did not yield the matter ostensibly, but the Assembly had the habit of adjourning when it pleased, and nothing could be done, so that in time the policy with which we are so well acquainted in the United States became fully established.

In 1709 Governor Gookin sent word to the Assembly, "I expect the House shall not adjourn any longer than from day to day, till the business further recommended to you this morning shall be issued." Here was a direct challenge, and Divid Lloyd, then Speaker, accepted it. With an unanimous House behind him, he passed resolutions, announcing that they would not attend to the business recommended, and would adjourn when it suited them, which, as harvest was approaching, they immediately proceeded to do. It is not giving Lloyd too much credit to say that his influence largely secured to the people of Pennsylvania the invaluable right of an independent legislature.

Penn was a full believer in civil liberty, as the advanced 


\section{POLITICAL LEADERS OF PENNSYLVANIA}

men of the times construed it, but he was an enthusiast for religious liberty and equality among the sects. He placed this principle in the forefront of all his constitutions, and when he gave the final one in 1701 he asked that his people should take the opportunity to propose any provisions which would better secure their rights. The most of them had not, as he had, any broad conception of the value of these intangible matters, but they did want good titles to their property, low taxes, good roads, and all the factors which would lead to permanent material prosperity. He was rather disgusted when in response to his liberal offers, the House sent in a reply dealing only with some of these, to him, minor matters.

His financial circumstances were such that he could not give away too many of his perquisites, for the expenses of government which fell upon him were in excess of his total receipts. Hence, some of these matters were left undetermined and afforded grounds of difference. All might, however, have been happily adjusted had he remained in the country or sent a judicious deputy. But, after the death of Andrew Hamilton, whom he first appointed, he sent over a vigorous, but not very judicious, man in the person of John Evans.

Logan and other of Penn's best friends rallied around him, but Lloyd was in popular control, and for three years (17021705) as Speaker of the Assembly, he ruled the Province with a high hand, finding abundant causes to quarrel with the Governor and Council and using them to the best advantage.

The matter culminated in a list of grievances to be sent by the House to William Penn in England. This document had a remarkable history, and was a source of contention for years to come.

In the first place it was not addressed to Penn directly, 
but to certain English Friends, who were more or less inimical to him. By a strange series of accidents, the boat carrying it was captured by a privateer and taken to France, and the bearer made a prisoner. He disclosed his package to a brother prisoner, who begged it of him, and, being a friend of Penn, forwarded it to the man from whom Lloyd meant to keep it till it had done its work secretly among the enemies of the Proprietary.

Equally irregular was the method of its passage through the House. It was brought up just at the close of a session of the Assembly in August, 1704, when it was too late to write it out in full and have it formally passed upon. The heads were drawn up and a committee was authorized to phrase them properly and forward the product - at least so the minutes say; but Logan tells us, and his word is supported by Isaac Norris, that the statement was seen by three men only, David Lloyd, Griffith Jones and Joseph Wilcox; that the minute giving the matter over to a committee was interpolated after the adjournment, and that it was signed by David Lloyd as Speaker after his term had expired.

Lloyd defended himself ably in a paper to the Assembly in 1709 against these charges. He does not deny that the papers were written but intimates that Logan got possession of them by unfair means and that the interpolations were sanctioned by the committee or as many of them as could be procured at the time.

The heads agreed upon by the Assembly referred to certain charges against Penn relating to the failure to perform his duty as Proprietary according to his own Charter and agreements. He had instructed his Deputy to issue writs for election when the House had a right to assemble according to its own adjournment. He had obtained money to secure the ratification of laws in England, especially those 
giving relief to Friends in the matter of oaths, but had not accomplished the purpose. His surveyors of land had keen inefficient or worse. He had commissioned the Judges and they were devoted to his own interests as against those of the people.

The remonstrance was accompanied by a letter from David Lloyd which was even more a bitter pill for the Proprietary. It told these unfriendly men "how we have been abused by trusting William Penn," and emphasized the disadvantage to the Province brought upon it by "the revels and disorders of young William Penn and his gang of loose fellows."

It is not a matter of wonder that William Penn who was never expected to see this epistle did not feel pleasantly toward the writer in the succeeding years, and that he was quite willing to believe the damaging stories of him in Logan's letters.

But Lloyd had overreached himself. The Assembly chosen in the fall of 1705 was of a different sort. There was a strong reaction in favor of Penn and Logan. David Lloyd was defeated for election in Philadelphia County, which he had previously represented, but got in from the city. He lost the Speakership, and the Assembly, dropping the quarrels of the past, devoted its time to useful legislation.

Now was the time when a good Governor could have kept the temper of the people sweet and at the same time resisted unjust claims against the Proprietary. But they had anything but a good Governor. By a series of inexplicable follies, he threw away all his advantages. He prosecuted an old member of the Assembly, William Biles, for saying outside the House, "The Governor is but a boy; we'll kick him out." He attempted to discredit Friends' testimony against war by raising a false report of the approach 
of a French fleet and calling on every one to arm, hoping that the Friends would thus compromise themselves. Instead of which they went to meeting. He built a fort at New Castle, and attempted to extort "powder money" illegally from owners of ships who were mostly of his own party.

In addition, he was irregular in his own life, joined with young Penn in his revels, and bore no good name in a community of strict Quakers. His own friends had to apologize for him, and Logan finally advised the recall, but as a result again Lloyd was triumphant. In 1707 and the two following years he was elected Speaker, resisted Evans and Logan with acrimony and success, and carried the Province with him.

Nor did matters change greatly when Penn in 1709 sent over Charles Gookin to supersede Evans. The personal faults of Evans were not reproduced in Gookin, but he was obstinate and headstrong, and perhaps, as he himself intimated, a little unbalanced mentally.

There were, however, two underlying causes for the trouble. One was that Penn was now in desperate financial straits, and could not yield his perquisites except at the cost of absolute ruin. His part of the expenses of government had to be borne, the quit-rents were coming in slowly, and his steward, Ford, had cheated him out of his fortune. The income from fines, licenses and other governmental functions were his by the arrangement previously made, and he could not afford to yield them.

The other was that while Deputy Governors changed, Logan remained. He could not always control the unwise acts of the Deputies, but he could largely influence general policy and was absolutely faithful to the Penn interests. The matters for which Lloyd contended were in the interests of the larger democracy and prosperity of the colony, 


\section{8}

but Penn could not afford to give up his undoubted rights, and Logan would not yield one iota to popular clamor. Lloyd was right in looking upon Logan as his great antagonist. Both were determined and fearless, and personal feeling was added to political diversity of interests.

One of the subjects about which the controversy raged was the composition of the courts of Justice. The charter of Charles II to William Penn gave him the right to establish courts and appoint their officers. He finally allowed the Assembly to draw up bills for such establishment, but retained the appointment of judges and elerks. As Penn's interests were larger than those of any other individual, Lloyd's elaim was that these officers should be independent of any obligations to him. There appear to have been no serious complaints as to the character of these officials, or that substantial justice was not done.

Again, in a community of Friends, it was of vital consequence that a juror or witness should be accepted on his affirmation, for he would not swear. It would be impossible to secure competent administration of justice without Friends, for in all the country communities they constituted nearly all the responsible people. There is no doubt that Penn appreciated this, but the charge of Lloyd was that he did not suceed in having laws ratified in England making provision for the full acceptance of the affirmation as equivalent to the oath.

Then there was the burning question of the licensing of public houses. Lloyd and the Assembly claimed that this was one of the proper functions of the courts and that the licensees should be appointed by local authority rather than by the Proprietary, so as to secure the choice of proper persons, who would restrain drunkenness and attendant crimes.

All these and other matters were to be fought through between the Governor and Logan on one side and Lloyd and the Assembly on the other. 
In the fall of 1706 Lloyd had a bill passed through the Assembly for a Supreme Court with three judges to which appeals could be made, also local courts for the counties for ordinary crimes, having also the power to grant licenses for taverns - providing that all fines should go toward the payment of the judges, who should be removable by the Assembly and therefore out of reach of Proprietary influence; that the judges should appoint the clerks, and that freeholders should not be imprisoned for debt.

This, of course, would be a great step in advance towards popular control of the course of justice. The Governor objected to it in toto. There was no need for more than one Justice of the Supreme Court - fines and fees belonged to the Proprietary, and judges and clerks should not be independent of him. It was a Proprietary prerogative which the Assembly had no authority to question, granted by the charter and due to him in return for his large concessions and care of the province.

The Governor threatened to establish courts on his own authority, as the royal charter empowered him to do in certain cases, but the Assembly told him that any one who should advise this would be considered an enemy of the country.

A conference was arranged between the Council and Assembly and a point of etiquette row threatened a complete stop to legislation. After the matter had been debated courteously for a time Lloyd neglected to rise when he spoke. The Governor commanded him to do so. To Lloyd this command was sufficient to arouse his pugnacity and he refused to obey, saying that he represented the people and in an open conference no special deference to the Governor was necessary. This broke up the conference. The Assembly sent a semi-apologetic message to the Governor, and Lloyd himself wrote a defense which could 
hardly be called an apology, ending with these words, characteristic of the man: "I do solemnly declare that my refusal to comply with the Governor's humour (for so I conceive it to be when he exerts his command when he should not) was not with a clesign to affront him but to show my dissent to that which I thought had a tendency to frustrate the freedom of conferences; not knowing, if I complied with this, whether the next command would not more highly affect the rights and privileges of this house which I am conscientiously concerned to maintain everywhere, and if in this I have done any thing unbecoming the station you have put me in I shall freely submit to your censure."

The Governor tried to secure a more personal apology, but he never received it, and the incident added to the bitterness of the times.

Ultimately compromises were reached embracing the most for which Lloyd had striven. The Proprietary retained the right to appoint clerks of the courts and holders of licenses, but these could be nominated by provincial bodies. Judges independent of the Penn interests were not appointed by the Crown according to Lloyd's plan, but men of highest character were chosen, and Lloyd himself did not disdain to accept a few years later the office of Chief Justice from his patrons' hands.

But Lloyd and Logan in the forefront of the controversy recognized, each the other, as the chief obstacle to his plans. Penn sent over pressing advice to impeach Lloyd, for accepting office illegally under Thomas Lloyd and for his irregular actions in the case of the remonstrance of 1704 . Logan said that there were no substantial grounds on which to build an impeachment and was too wise to attempt it. But Lloyd with the full Assembly back of him entered joyously upon an impeachment of Logan. The real reason was that Logan had the brains and courage of the administra- 
tion and Lloyd was right in considering him the chief obstacle in the way. Much time and much legal fencing were employed, but the matter came to an end when the Council decided that it had no authority to try impeachments and the Secretary was saved. He shortly after went to England on a visit and returned stronger than ever.

Governor Gookin next tried a tilt with Lloyd in the matter of an appropriation for a military expedition against the French in Canadia. In a rather facetious letter he himself tells the results: "The Queen having honored me with her commands that this Province should furnish out 150 men for its expedition against Canada, I called an Assembly and demanded $£ 4,000$; they being all Quakers, after much delay resolved, N. C., that it was contrary to their religious principles to hire men to kill one another. I told some of them the Queen did not hire men to kill one another, but to destroy her enemies. One of them answered the Assembly understood English. After I had tried all ways to bring them to reason they again resolved, N. C., that they could not directly or indirectly raise money for an expedition to Canada, but they had voted the Queen $£ 500$ as a token of their respect, etc., and that the money should be put into a safe hand till they were satisfied from England it should not be employed for the use of war. I told them the Queen did not want such a sum, but being a pious and good women perhaps she might give it to the clergy sent hither for the propagation of the Gospel; one of them answered that was worse than the other, on which arose a debate in the Assembly whether they should give money or not, since it might be employed for the use of war, or against their future establishment, and after much wise debate it was carried in the affirmative by one voice only. Their number is 26. ${ }^{1}$ They are entirely governed by their speaker, one Darid Lloyd."

${ }^{1}$ Fight from each county and two from Philadelphia. 
But the people finally got tired of the bickerings of parties. Lloyd in his contest with Evans and Logan had again overstepped the mark. In the fall of 1710 the eleetion showed a eompletely new Assembly. Neither Lloyd nor any of his followers was returned. Instead there came in William Trent, Jonathan Dickinson, Caleb Pusey, Richard Hill, Isaae Norris and other of the best friends of William Penn. There was what would be ealled in modern politics "a tidal wave" which showed that, except for serious errors by deputies, the heart of the people was true to the Founder. Impeachments were dropped, $£ 2,000$ was voted "for the Queen's use," abundanee of useful legislation, held back by the partisanship of previous years was created, and the youthful province having passed over the perilous times of infaney, started fairly on its successful career.

Lloyd was temporarily laid aside, and yet his great services in founding the real democraey of Pennsylvania under the generous provisions of the Founder had largely been accomplished. Whether he felt this or whether about this time he experienced a real change of heart, as suggested by some biographers, may never be known, but certain it is that the peaceful and also effective part of his life and public employment was yet to follow in a seore of years of honored and honorable service.

He did not remain long out of office. About 1711 he moved his residenee from Philadelphia to Chester; in the same year he was eleeted to the Assembly from Chester County, but did not receive the Speakership. This also happened in 1712 and 1713 . In 1714, however, he was unanimously chosen Speaker, for which scrvice, in a general way, no one could compete with him in capability. The reeords of the time indicate the great prosperity of the Province growing in wealth and population at a rapid rate, 
and the absence of the unhappy divisions of earlier years. A further indication of the softening of the partisan asperities of the first decade of the century was the appointment of David Lloyd as Chief Justice in 1718 to succeed his father-in-law, Joseph Growdon, who had held the position for ten years preceding and who had frequently opposed him in the House.

In May, 1717, Sir William Keith succeeded Governor Gookin. He was selected by Hannah Penn, for while her husband was still alive, he had so far failed in body and mind as to be incapable of business and about a year later died.

Keith was a wise and politic Governor. He had the confidence of Logan and Norris and he now undertook to secure the support of Lloyd and the Assembly. He rightly judged that the Quakers must be kept friendly to him if he would be preserved from endless disputes. He found them troubled with their difficulties as to oaths, and in a diplomatic way suggested that they should adopt the English penal code and in exchange receive the right to affirm instead of swearing. The same bill which made an affirmation legal for those whose consciences would not allow them to swear, extended capital punishment to burglary, rape, counterfeiting and other serious crimes. The mild penal code of Penn wherein murder only was made a capital offense and which was applied to one case only prior to 1700 , died with him. There seems to have been no testimony against capital punishment among Friends. David Lloyd, a member in good standing, drew up the bill, it was passed by a Quaker Assembly, approved by a Quaker Council and endorsed by a Quaker community. Had they felt as most modern Friends do, it may be considered as doubtful whether the right to affirm would have been deemed a sufficient compensation for a severe code involv- 


\section{I04 POLITICAL LEADERS OF PENNSYLVANIA}

ing capital punishment. We can easily appreciate how much the affirmation meant to them. For without it they would have been deprived of all share in government and anarchy would have resulted. But we can hardly appreciate that a testimony against capital punishment did not mean as much.

Governor Keith's entire attitude was gracious and conciliatory. He had learned from the experience of former Governors how hard a task it was to contest a popular Assembly led by David Lloyd and he went over completely to the other side, yet at first not so imprudently as to draw fire from Logan and his friends. Lloyd was made Chief Justice and the Governor assumed the rôle of protector of popular liberties, thus procuring for himself immediate support. He had his reward in prompt votes for salary and easy times.

Material prosperity accompanied political peace. There was only one drawback, the lack of ready money. Coin was drained to Europe to make the purchases needed by a growing community which imported far more than it exported. Barter was common, but was inconvenient. Keith shrewdly suggested a paper currency. Norris and Logan objected and their fears were echoed from England. There seemed to be abundant ground for hesitation. Many of the Colonies had tried it, and with disastrous results. As a little stimulated trade, more, they argued, would be better; and they increased the amount until it lost its purchasing power and depreciated. But Lloyd and his friends urged it and Keith had his way.

This balance of forces was just what was needed to make it a success. It was issued sparingly on the security of land and plate. It stimulated trade and never depreciated. Pennsylvania taught the lesson, and all through her colonial history she had an abundant stable paper currency, due 
largely to the initiative of Keith and Lloyd and the caution of Logan. But the latter element did not win the popular appreciation as did the former, and Keith became immensely popular. The Assembly sent him a congratulatory letter and a vote of supplies. The Council, which had been largely ignored by the Governor, as indeed by the charter of 1701 he had a right to ignore it, as having no necessary function in legislation, drew away from him, and in $\mathbf{1 7 2 2}$ Keith, feeling himself strong enough to dispense with it, removed Logan from his offices as Councillor and Secretary, thus foreing him out of the government entirely.

But Logan was still strong with Hannah Penn, and sailing to England he soon returned with definite instructions to Keith, threatening him with removal. Keith was constitutionally right, but he was the servant of the heirs of William Penn, and they trusted Logan. He concluded to stand by his plans, and to set against proprietary powers, popular support. Logan attacked him in a long memorial, and David, with some of the spirit and vigor of a score of years earlier, entered the lists against his old adversary. His abundant citation of authorities and able legal arguments were conclusive, if such matters could settle the question. He was again Speaker of the Assembly as well as Chief Justice, and that body under his guidance sent to Hannah Penn a remonstrance against the contemplated removal of the Governor and a eulogy of his services to the state.

From the Lloyd point of view the administration of Keith was the consummation of the efforts for which he had been struggling for many years. The Assembly, as the representatives of the people, had been exalted and their rights defined and extended. The Courts had been created by the act of Assembly, made reasonably responsive to popular demands and the great democratic leader placed at the head of the system. The Quakers had received that for which 
Lloyd had always pleaded - the right to a full participation in government without being sworn. English wars had ceased to disturb the petceable principles of the ruling sect, and to crown all a stable material prosperity, satisfying alike to proprietaries and people, had settled down upon the province. It is not to be wondered at that Lloyd in his old age awakened from his quietude to defend the cause with which he had been so long and so intimately associated in his earlier years.

With such a record and such support Keith thought he could defy England. He felt that the heirs would hardly dare to remove him, and if they did he imagined he might even overthrow the proprietary government itself and make a crown colony, with himself as Governor.

But with all that he had learned he under-estimated the strength of the sentiment of the people of Pennsylvania to the Founder's family, and when the day of his removal came he had nothing to do but hand over his office to old Patrick Gordon, who, in 1726, had been sent over to supersede him.

Lloyd also accepted the failure of his plans gracefully. Indeed, he and the Assembly may almost be accused of apostasy by allowing their enthusiasm for Keith to pass away. When the ex-Governor had himself elected to the next Assembly and became a candidate for Speaker, Lloyd turned against him and easily defeated him. His further career was neither happy nor dignified, and the unwisdom of his closing years was allowed to cloud his great services to the cause of free government.

This was the last important public controversy of David Lloyd. In honored performance of his duties as Chief Justice he lived until 1731 . He died aged 75 years.

After this sketch of David Lloyd's life it is unnecessary to say much as to his character. He was a great lawyer, probably the greatest of colonial Pennsylvania. In this 
capacity he was always efficient and faithful to his clients, sometimes possibly at the expense of pure morality. In most legal circles this would hardly seem a fault, but the Quakers of the time from their lay standpoint could not always justify him.

As a politician he was equally competent. He led by sheer ability and persistence. Logan tells us - and this was at the time before their personal differences had developed: "He is a man very stiff in all his undertakings, of a sound judgment and a good lawyer, but extremely pertinacious and somewhat revengeful." Proud says cautiously: "His political talents seem rather to divide than to unite; a policy that may suit the crafty politician but must ever be disclaimed by the Christian statesman."

It is unfair to assume that Logan's further estimates of his character, given in the heat of their partisan controversy, are conclusive. He tells, however, how it was that Lloyd maintained his great influence in the Assembly, and we may at least guess the truth from his statements. "The generality (of the Assemblymen) are honest and well inclined and out of the Assembly are very good men, but when got together I know not how they are infatuated and led by smooth stories," and again he speaks of the great influence "he has over the majority composed of designing and weak men," and again "He carries so fair with our weak country people and those that have long looked upon him to be the champion of the Friends' cause in government matters in former times that there is no possessing them." And again, "Jones and Wilcox stand by him in mischievous intentions. The rest think they are faithfully discharging their duty to the country."

Lloyd was the great leader of the country members, and these were a large majority of the Assembly. They were worthy, honest men, but Lloyd was so vastly their superior 
in learning, ability and political skill that he practically voted them as he would. Whenever the Logan party got control a much abler and more responsible body of men appeared in the Assembly, only to be thrown aside when Lloyd returned to power.

David Lloyd became for the times wealthy, but no suspicion of mercenary methods appears in his politics. He probably made his money by his legal practice and still more by advances on real estate. His salary as Chief Justice was generally $£ 150$ a year, and the Assembly paid him for his labors in framing legislation and writing addresses, but his public work would not explain more than a poor living.

As a Friend we do not find him prominently mentioned in the minutes of the meetings - at least in comparison with the records of Samuel Carpenter, Isaac Norris and many another. Perhaps there was, as the minutes of Philadelphia Monthly Meeting in the case of the dispute with Pastorius show, a lurking suspicion that his methods could not be fully justified.

It is a significant fact, however, that Chester Monthly Meeting was the most persistent of any in urging upon the Yearly Meeting the iniquity of the slave trade and the necessity to take strong action. ${ }^{1}$ The first one of these epistles was in 1711, which was the year Lloyd moved from Philadelphia to Chester, and the last was in 1730 , the year before he died, and their style suggests the bold, vigorous, uneompromising spirit that penned the Assembly addresses of the same period. This is not conclusive, but it seems highly probable that the attitude of the early Friends of Pennsylvania towards questions of slavery was largely due to the clear thinking and fearless writing of Darid Lloyd.

David Lloyd's second wife was Grace Growdon, the 1 See Whittier's Introduction to "John Woolman's Journal." 
daughter of Joseph Growdon, of Bucks County, one of the leading men of the colony and in the main an adherent of the Penn-Logan party. Why the father cut off Grace with five shillings in his will is probably not known, but he frequently opposed his son-in-law in politics. They were married in 1697 . Their only son died when four years old, as the result, it is stated, of fright because he was placed in a dark closet for punishment during the absence of his parents. David Lloyd had no descendents to care for his reputation, and except in the public records, and a defense in the Penn-Logan correspondence, he beft but little about himself.

He had landed interests in Chester and represented Chester County in the Assembly until 1700. Then he transferred his residence to Philadelphia, and that county made him its representative for the coming decade. Afterwards he moved to Chester for his declining years.

Grace Lloyd was a minister in the Society of Friends and was much loved and trusted. There is an account in the life of Jane Hoskins ${ }^{1}$ which gives a little insight into the family and religious life of David and Grace Lloyd.

Jane Fenn (afterwards Hoskins) came over to Pennsylvania in 1712, in response to a call of duty. She was of poor circumstances, and engaged herself as a servant in Friends' families, at the same time diligently attending religious meetings. She tells her own story: "One First-day after I had sat some time in Haverford Meeting, David Lloyd from Chester, with his wife and several other Friends came into meeting. As soon as they were seated, it was as though it had been spoken to me, 'These are the people with whom thou must go and settle.' They being strangers to me, and appearing as persons of distinction, I said, Lord, how can such an one as I get acquainted with people

${ }^{1}$ Friends' Lihrary, Yol. I, p. 4'50, ete. 


\section{Io POLITICAL LEADERS OF PENNSYLVANIA}

who appear so mueh above the common rank. The word was in my soul, 'Be still, I will make way for thee in their hearts - they shall seek to thee.' I knew not what to think of this, and was afraid it might be a temptation of Satan; yet was contented in the thought, that the Lord who never yet failed, was all-sufficient to provide for me. At that instant a great stillness came over me, and I felt the love of my heavenly Father to affect me in a very uncommon manner. I afterwards understood that David Lloyd and his wife fixed their eyes upon me, felt a near sympathy with me, such as they had never known towards a stranger before, and said in their hearts, this young woman is or will be a preacher. They were both tendered, and it was fixed in their minds, that they were to take me under their eare, and nurse me for the Lord's service, with a promise that his blessing should attend them. This I had from their own mouths after I lived with them."

Jane Fenn became "an upper servant" in the family of David Lloyd. This came in response to a suggestion of an English Friend who had become interested in her religious life. "After dinner," she says, " the Friend spoke to David Lloyd and his wife. "Take this young woman, make her your adopted child and give her liberty to go wherever Truth leads.' . . . Grace Lloyd then took me into another apartment and told me how she and her husband were drawn in love to me the first time they saw me at Haverford."

Jane Fenn beeame a minister and made extensive travels through other colonies, to Barbadoes and later to Ireland and England in religious service. She returned from a foreign trip in 1730 "and was affectionately received by my kind friends and benefactors, David and Grace Lloyd.

"Soon after my arrival David Lloyd was taken ill with his last sickness, during which I thought it my duty to at- 
tend on him as usual. On the 6 th of the second month, 1731, he departed this life; and in him I lost a father, and a sure friend. In all the journeys I went, whilst he lived, he cheerfully supplied me with the necessaries requisite. He was exemplary in his family, treating all about him with humanity, choosing rather to be loved than feared. He was diligent in attending meetings for worship, and those of his servants who inclined to go to meetings, he allowed to perform that necessary duty. After my arrival I did not live as an hired servant with David Lloyd, or with his widow, though I remained with her, at her request, till I married, which was in the year 1738."

The value of David Lloyd's services to the state will lie, (1) in his successful insistence upon an independent legislature. He had evidently a large though undetermined share in procuring from Penn the charter of 1701, which cut the Council out of all legislative powers. He was ever keen to notice any small attempts to reinstate it in such powers in inclirect ways. He had the modern faith in the people and was jealous of any tendency which would circumscribe the privilege of the elective Assembly. (2) He, more than any other man, fought out the Quaker battle for the affirmation instead of the oath, and for the further contest for a form of affirmation which was simply a promise, without bringing in the name of God, which in some minds made it a modified oath; and (3) while Penn arranged for an executive and a legislature, he omitted to make provision for a judiciary, probably intending to create this by his own authority under his charter from the King. The form which the machinery of the courts finally assumed and its large independence of proprietary influence, was the great work of David Lloyd.

In the worls of Proud, it is true that Iloyd's efforts "tended rather to divide than to unite." He could not 


\section{POLITICAL LEADERS OF PENNSYLVANIA}

work comfortably with opponents and bring them to his own point of view. By his staunch Quakerism and superior knowledge he brought his followers into loyal allegiance, but he was uncompromising in his attitude towards opposition. Whether the beneficent results of his career could have been achieved by a gentler spirit, less tenacious of every little point, arousing less personal antagonism, more gracious and diplomatic in argument, may be difficult to determine with certainty. It is not unreasonable so to think.

But it is difficult to estimate the full value of his services. His strong personality, his persistent energy, his extreme perception of the value of liberty and determination to defend it against any, even small, encroachments, made him a strong factor, perhaps after William Penn the strongest factor, in building up the colonial Commonwealth on the basis of popular rights. Had he known how the letters of his great rival to Penn would have formed the basis of history, he might have left stronger defences of his work and positions. There is not much evidence, however, that he considered the judgment of the future as of consequence. He was too busy attaining immediate objects. It is only in quite recent times that his name and reputation have emerged from the mass of statements against him contained in the voluminous letters of political opponents and their descendants. Without family, with a following, numerous and devoted but not literary, with an independence which kept him in somewhat doubtful relations to many of the prominent Friends of the Yearly Meeting, without adequate biography, he has hardly received the attention which his undoubtedly great public services demand.

His countrymen appreciated him. The Rev. Abel Morgan wrote a Welsh Concordance to the Bible, which was published in 1730 and dedicated to Chief Justice Lloyd as 
a token of esteem and an appreciation of his devotion to the principles of liberty. He aided in the revision of the translation of a religious treatise called "A Salutation to the Britains." During his later years he published two small treatises: "A Vindication of the Legislative Powers," and "A Further Vindication of the Rights and Privileges of the People of Pennsylvania."

These were the occupations of his declining years of peaceful repose in contrast with the stirring scenes of his earlier life. They indicate, however, that the trend of his thoughts never changed. 


\section{JAMES LOGAN}

Ir is usually stated that James Logan was a descendant of a noble Logan family of Scotland. This has probably not been certainly proven. It is sufficient for our purpose to state that his father was Patrick Logan, a Presbyterian minister who joined Friends and moved to the north of Ireland where James was born. He thus inherited his Quakerism. There are however various events in his life which show that he also inherited that vigorous militant blood of the people commonly called Scotch-Irish, who so much disturbed the Quaker relations with the Indians on the frontiers of Pennsylvania, who largely settled the western end of the province and spread themselves down the Appalachian country to the south, who were the choicest enemies of Quakerism whenever they came into conflict, and through whose influence Pennsylvania was largely drawn into the Revolutionary War.

$\mathrm{He}$ did not much like the company of his compatriots that eame later in provincial times. They were the great obstacles in the way of his Indian policy which he had inherited from William Penn and which he faithfully adhered to, and he did not fancy their rough uncouth manners. "It is strange that they thus crowd in where they are not wanted. . . . The Indians themselves are alarmed at the swarms of strangers and we are afraid of a breach between them, for the Irish are very rough to them," he says, - a prophecy soon verified.

He was born on October 20th, 1674, at Lurgan. His father was a teacher and gave him a good education. $\mathrm{He}$ 
became proficient in Hebrew, Greek and Latin. The Irish fighting which was terminated by the Battle of the Boyne sent the family first to Scotland and then to Bristol, England, where he carried on his studies in mathematics and modern languages and assisted his father in teaching. In 1699 William Pemn, who had many acquaintances in Bristol where his second wife had lived, came into contact with James Logan and asked him to go with him as secretary of his province. They reached Philadelphia early in December. Logan was then 25 years old, one of the few highly educated men of the settlement.

Thus began his colonial life. As secretary and agent of the Penn family, trustee under Penn's will, secretary of the Council, Mayor of Philadelphia, Chief Justice of the Province, and for a time acting Lieutenant-Governor, he was for fifty years a most potential influence, perhaps the most potential influence for this half century, in provincial affairs. It is often said and with a large element of truth that Penn was weak in his judgment of men. But he made no mistake in this instance. Save for a certain pugnacity which was sometimes tactless and made him enemies, there never was a more faithful and intelligent manager of another man's affairs; and this refers equally to Penn's political and his financial interests.

He came into his Quaker membership by birthright rather than by conviction and while in the main loyal to the Society, refused to accept in full all its usual testimonies. On his first voyage from England his boat was approached by a supposed pirate which afterwards proved to be a friend. Penn and the Friends held a meeting in the cabin. Logan assisted the sailors on deck to prepare the guns for defense. After the danger was over Penn reproved him for his martial activity. It seems to have been a surprise to him that Friends disapproved of physical weapons for 


\section{6 POLITICAL LEADERS OF PENNSYLVANIA}

defense, and he did not see how his master could govern a province on this basis. That he had not known it is an indication of rather a lax acquaintance with the history of the Society.

Shortly after he came to Philadelphia he found that Daniel Cooper from New Jersey had settled upon the Reed Islands in the Delaware River which belonged to Penn. Logan with Edward Shippen, Jr., and the Sheriff of Philadelphia went out armed to arrest him. No blood was shed but the meeting thought it necessary to set the matter straight and "clear the Truth." The two Friends were required to write papers of apology and after one or two trials produced such as were satisfactory to the meeting. The charge against Logan was "his going with armed men or suffering arms to go in company with him in a hostile manner when he ought to have gone in a peaceable manner according to the profession he makes." Logan's acknowledgment is interesting:-

"Whereas upon a provocation given by Daniel Cooper of West Jersey, injuriously (as was judged) to our Proprietary's right and contrary to authority, invading in the 5th mo. last one of the Reed islands of Delaware, over against this city, I undertook to go over to ye said island to divert him from proceeding in his design, accompanied with the Sheriff of Philada. who hearing of an opposition designed, took with him some other persons with fire arms for ye greater awe of such as should attempt to oppose. And whereas oecasion hath been or may be taken from the said arms being earried in my company to reflect not only upon me as concerned for the Proprietary, but also upon the profession of Gods Truth owned by and amongst us, I do therefore in a true sense of the inconveniences that have naturally ensued from the said aetion and its contrariety to the said profession heartily regret my complying with or being in anywise concerned in that method which ministers such oceasion and do in sincerity declare that could I have foreseen the ill consequences of it I should by no means have engaged in it. 
"Hoping and earnestly desiring that it may please God, the Author of all good councill and direction so to enlighten my understanding by his spirit that I may avoid not only all such occasions but all others that by being contrary to his divine will may minister offence for the future,

\section{JAMES Logan."}

Hardly had this matter been settled when he had some difficulty with Thomas Story a young and accomplished Quaker minister. Thomas Story made some unknown charge against James Logan "both upon his own and Truths account" and they mutually agreed to leave it to the determination of the meeting, giving up all papers in their possession. The matter was somehow amicably settled and the meeting decreed that all these papers should be burned in the presence of the two men, each declaring that no others existed. This was done and no one will ever know the cause of the difficulty from the meeting records.

Profane history however tells us that these two young men were suitors for the hand of Anne Shippen, the daughter of the mayor of Philadelphia, and that Story won the prize. That Logan's rivalry caused some actions of which the meeting disapproved is not an impossible suggestion. The disappointment seems to have been generally known and to have reached Penn's ears in England. "I am anxiously griered for thy unhappy love," he writes, "for thy sake and my own, for T. S. and thy discord has been of no service here any more than there." But the affair was settled. The two became excellent friends. "He and I are great friends," Logan said a couple of years later, "for I think the whole business is not now worth a quarrel." In later years a long correspondence of considerable interest, which has been published, was kept up between the two scholars relating to scientific and philosophical matters.

From Isaac Norris's description one ought to find it diffi- 


\section{8 POLITICAL LEADERS OF PENNSYLVANIA}

cult to quarrel with Thomas Story. "He was bred a lawyer but laid that aside for the gospel. His conversation as a man was sweet, gentle, and extremely affable; his spirit as a Christian extraordinarily humble; and I have observed him to watch even against his own abilities lest they should appear to exalt him in the opinion of any."

Other cases where James Logan differed from the Quaker authorities will be mentioned later. But the relations were always sympathetic. He was careful to emphasize his membership whenever proper, his family was perhaps more Friendly than he, and his integrity and high ideals were never questioned, except by his political opponents in the heat of controversy. He however never took prominent part in church affairs, held few official positions, and there seems to have been a frank recognition of certain differences to which in time both sides adjusted themselves.

"Traveling Friends," he writes to Penn, "will give no good account of my strictness. I am willing all should know that I neither am nor ever was a strict professor and I will make my outside appearance agree with what I really know myself to be."

When Penn left him in 1701 Logan plunged into the work with his characteristic ardor and energy. The quit-rents had to be collected and this was no light matter from a people, comfortably living it is true, but with but little ready money. Individually small (one shilling per hundred acres or thereabouts) it made a great difference to William Penn that they should come in promptly for he was greatly out of funds through his experiment. The rough surveys had to be revised and when settlers found that they had more or less land than they supposed, adjustments had to be made. Penn had been rather profuse and uneven in his promises, titles were uncertain, and records in default. The tangle must be straightened out. Logan had a clear head 
and absolute fidelity, but his manners were ungracious and his instructions, which he could not well disclose, frequently hampered his free action. His was not a popular part but he did his duty. Penn's best friends stood by him but the country people were not pleased by his stringent demands and his unsympathetic attitude, however in their hearts they might recognize the general justice of his measures. Thus he alienated support and his future battles with David Lloyd were made more difficult, while his differences with his monthly meeting did not help matters.

Why it was difficult to collect the quit-rents and other dues manifestly owing to Penn is told by James Logan. "No trade," he writes, "no money coming in, nothing to pay in but wheat and no sale for that." And again, "Were the country people ever so willing nay were it to redeem their lives they cannot now raise money." Under these circumstances the only remedy was distraint. The difficulties of collection were so great and the feeling for the farmers so strong that men could not be found to apply the law.

$\mathrm{He}$ writes again, "The people will not pay without distress (distraint). Friends are willing to pay but not to bear all the burden themselves, while others obstinately save their money, and none can be prevailed upon without much reluctancy and compulsion to do that unkind office to their neighbors." Later the meetings set their machinery to work and insisted that the members should pay their just dues. But the difficulty, until paper money was issued some 40 years after the founding, consisted in the fact that the province was drained of money to pay for importations which the developing country must have. Logan writes again in 1705: "We have now tis true nor money nor credit, yet we live quiet and easy and want nothing," and Penn responds "I am glad of thy opinion of the people that it arises from want and not disaffection that they have not paid." 


\section{0

The ownership of William Penn and heirs was of three sorts. (1) The common land sold at uniform prices, at the start about $£ 5$ per 100 acres, to all satisfactory purchasers, who were also to pay a quit-rent ${ }^{1}$ of one shilling per 100 acres per year. (2) The manors belonging to the proprietors jointly, usually the best 10,000 contiguous acres out of every 100,000 acres sold. (3) Land owned by individual proprietors bought as any one else would. There was a condition that the first purchasers of 5000 acres, for which the price was fixed at $£ 100$, should have a town lot of liberal dimensions within the limits of the city of Philadelphia or its "liberties," and this provision was extended pro rata to certain small purchasers. Land could be rented at a quitrent of one penny per acre. Masters might have 50 acres for each servant brought over and servants themselves also 50 acres each when the time of service was ended.

With this complicated system and the crude opportunities for keeping records it may be seen that the land office was for 50 years a scene of confusion and strife.

There were also difficulties in carrying out Penn's policy with the Indians. He had given instructions that strict honesty was to be used in buying lands of them and that purchase should precede settlement. But settlers pushed themselves into unoccupied lands without recognition either of Proprietor or Indian rights. In 1726 it was estimated that there were many thousand settlers, mostly Germans and Scotch-Irish, on land to which they had no legal right. This was a source of continuous trouble with the Indians which nothing but a general respect for "Onas" enabled Logan to keep in check.

1 This name originated beranse the renter was therehy "quit and free" from all other foudal services. According to English law something of the sort seemed necessary to the perfection of the title. 
In 1682, before Penn landed, his agent and cousin, William Markham, had bought of the Indians the land between the Neshaminy Creek and the Delaware River. Within a few years by several purchases, from various Indian ehiefs, several of them covering the same districts, titles to all of south-eastern Pennsylvania, as far back into the country as a man could travel with a horse in a two days journey, were secured. In 1694 Penn bought of the Five Nations the whole course of the Susquehanna through the province and confirmed it later by buying again of other tribes who objected to the claims of the Five Nations. So the various Indian titles, some very shadowy, were bought out. Attempts were made to dispossess settlers who passed over the legal boundaries. They were removed and their buildings burned. But they went in again as soon as the force withdrew.

Some of these troubles were at the time which we are considering still in the foreground but James Logan was entering on a task which was of immense service to the young province. His boundless hospitality to Indian chiefs, his sympathy for the Penn policy and ability in making it effective saved many a day of serious discord. For 50 years he conducted the most of the transactions with the red men with great success.

But if the land and Indian questions were troublesome for the young secretary, the political issue was even more importunate. The Deputy Governor selected by Penn did not live long and a young man of Logan's age, John Evans, was in 1704 selected as his successor. This proved a most unfortunate choice for all parties. He was not wise in his methods, had no sympathy with Friends and his life did not commend him to their favorable notice. With him came the oldest son of the proprietor by his first wife, William Pem, Jr. He had been something of a libertine but his 


\section{POLI'TICAL LEADERS OF PENNSYLVANIA}

father hoped that the influence of Logan aided by solid Friends like Samuel Carpenter and Isaac Norris would save him. Logan did his best, and for a time the experiment seemed likely to succeed. He was encouraged to find his pleasure in the woods and waters, teeming with game and fish, and to become interested in the political problems of the province of which he would probably be the proprietor. But Evans' influence was not good and after a drunken riot in the streets, the two were arrested at night for disorderly conduct. The legal question was soon patched up but the matter caused great heart-burnings both in England and Pennsylvania and was not without its political significance. The young heir shook the dust both of the province and the church off his feet and neither knew him again.

Had Governor Evans behaved himself Logan would have had but little trouble in maintaining the interests of the Proprietor. But there followed a series of unwise and provoking actions which quite unsettled the influence of the Secretary. David Lloyd was busily engaged in pressing the claims of the legislature to adjourn at its will and to be independent of executive control. He did this by virtue of his superior finesse and knowledge and by his staunch support of the Friendly position against war and oaths. Logan was quite his equal in ability but was known not to be so radical in his moral positions. Besides as the faithful guardian of the Penn interests he thought it necessary to support the governor.

The Remonstrance of $1704^{1}$ brought the smouldering controversy to a head and was the center about which the storm raged for a number of years. Neither leader hesitated to say hard words of the other. "That lurking snake, David Lloyd" is the eulogy sent to England by Logan. "The malignity and falsehood of James Logan" is Lloyd's

${ }^{1}$ See David Lloyd, p. 94. 
reference to his adversary. If the body of Friends of the time possessed the spirit of these leaders it would have to be admitted that the softening influence of their religion was not much in evidence. But while dealing with matters of consequence it was largely a politicians' fight. The body of Friends seemed to be interested spectators ready to turn the scale in favor of one side or the other as errors of "falsehood or malignity" withdrew their sympathy. Back of it was an undeniable love and respect for the absent Proprietor now in the depth of his financial difficulties, and, less to be commended, but only natural, a hope to improve their material conditions. Whether they very intelligently cared for the political and civil liberties which Lloyd so strenuously urged is more doubtful. If so it was largely due to his persistent advocacy, which, whatever the motive, made the province "safe for democracy."

Logan and his friends triumphed in the election of 1705 when a wave of loyalty for Penn swept the province. This unfortunately had the effect of increasing the presumption of the Governor. An elderly and injudicious Assemblyman, William Biles, sympathetic with the popular party, had made some indefinite threat outside the house that Evans was but a boy and "we will kick him out." For this the Governor had him arrested and put in prison and asked the house to expel him, which of course it refused to do, and asserted that its privileges had been violated by his arrest. However this did not seriously abate the strength of the Logan party which again carried the election of 1706 , electing Joseph Growdon as Speaker and passing much wholesome legislation without bickering.

Again Evans was his own worst enemy. Truly apprehensive that an attack by sea from the French fleet was imminent he attempted to induce the Assembly to appropriate money to place the province in a state of defense. But 


\section{POLITICAL LEADERS OF PENNSYLVANIA}

the Assembly, practically all Friends, would do nothing. He thought that their prineiples would fade away before a near danger and adopted a ruse to discredit them. On the day of the annual fair when the city was unusually full of people he had an accomplice send word from New Castle that the enemy's ships were in the river. Then mounting his horse with a drawn sword he rode through the streets asking the people to arm. The eity was duly alarmed. There was a great exodus of small eraft to the ereeks, plate was buried, and some families hid themselves. The Friends instead of arming as Evans had intended went to their regular midweek meeting and sat in quiet through the disturbance. They had not eompromised themselves and when later in the day the real facts developed the Governor was placed in an unexcusable situation much shorn of influence.

The next Assembly as the result of this farce went over to the opposition and Lloyd was again in power. James Logan was charged with being an accomplice in the plot by placing a French flag on a sloop which would have told the truth about the matter and sending signals to the Governor. This he denies in a letter to Penn and his general good sense and knowledge of Friends would seem to support the denial. His object he says in going down the river was to ascertain the truth, and abate the panic. He writes Penn "The entire body (of Friends) seems disgusted and piqued to the heart at the contrivances of that alarm which they think served only to expose them to their enemies here."

Then Evans tried another plan equally unfortunate for his popularity and this time directed mainly against his own adherents. He built a fort at New Castle and levied tribute in the shape of powder on all vessels entering or leaving Philadelphia. The restriction on trade was probably illegal and certainly unpopular, and Richard Hill, an old sea eaptain and now a prominent citizen, with two other Quaker 
merchants, undertook to sail his own vessel past the fort and test the right of the Governor to collect the tax. They stopped at the fort, informing the commander that their vessel was regularly cleared, and demanding that they should be allowed to pass. This was denied and Richard Hill himself took the helm and sailed by the fort, receiving a shot through the mainsail. The commander followed in an armed boat as did also Evans himself in another. The boat of the former was turned adrift and he himself kept a prisoner in the cabin. Landing at Salem they found Lord Cornbury, the Governor of New Jersey, to whom the exaction was equally distasteful. The prisoner was reprimanded and released and this ended the " powder money" exaction on the Delaware.

But Evans was hopelessly discredited in the minds of the Pennsylvanians, and Logan, who had stood by him as far as he could, as the representative of the Penn interests, shared his unpopularity. The Assemblies of 1707-8-9 were bitterly opposed to the Executive and to James Logan as its brains and motive power.

That official now came into the clutch of impeaclument proceedings. The Assembly was greatly incensed at the Governor and with some truth identified Logan with his actions. The secretary had also berome generally unpopular by his rigidity in collecting quit-rents and other of the dues of Penn. Moreover he could possibly be reached by legal proceedings while Evans could not. So they presented thirteen articles of impeachment against him relating to alleged misdeeds. They stated that he had illegally violated the constitution of 1701 by inserting in the Governor's commission a power to convene or dissolve the Assembly; that he had usurped certain powers in relation to surveying lands and reserving quit-rents; that he had prevented certain acts of assembly from being published 


\section{I26 POLITICAL LEADERS OF PENNSYLVANIA}

and that he had persuaded officials to accept their commissions from the Governor instead of by election of the people.

It is not improbable that Logan was technically guilty of some of these charges. He had in defense of the rights of the Proprietor and with an exalted sense of his own importance combined with a dislike amounting at times almost to contempt for Lloyd and the popular party, assumed powers which were legally indefensible.

The Governor stood by him and refused to entertain the charges on the ground that neither he nor the Council had power to try impeachments. Logan himself while professing a desire to have the case tried was unwilling to proceed until the proofs were published. There was much legal fencing on both sides which embittered the controversy, and the Assembly finally concluded to appeal directly to William Penn of England with their complaints against his own neglect of their interests.

This remonstrance wats more moderate than that of 1704 but reiterated the old charges. The Friends had not been relieved in the matter of oaths and hence were deprived of certain official positions; the Maryland boundary had not been settled; the royal sanction had not been secured for certain laws; the Deputy-Governor had attempted to establish a judiciary on his own authority; had refused to try Logan; had formed a militia, exacted " powder money," had been engaged in disorderly brawls in the city and in immoralities in Indian villages. The charges against Logan were repeated.

The people endorsed the Assembly electing practically the same members for 1709 and the impeachment proceedings were not allowed to drop. It is probably true that the Assembly was now composed of a weak set of men. The nerve was taken from Penn's friends by the exploits of Evans and they withdrew from the contest. This left the field 
to Lloyd's followers and he wanted such as he could manage. Logan, it is quite likely, made the most of their weaknesses when he wrote "In the worst of our former Assemblies we had seven or eight honest men of good sense. . . In the present we have not one left," and again "The last Assembly were all Friends in unity except [two]. But these present Gallimaco Fry (such a mixture as were never here in the assembly before) are the men it seems that are to manage in the name and for the interest of Friends when in reality they are neither of them or the church, but the leaders of them are made up of that bitter spirit raised by the foum scattered by George Keith at the time of the Separation." The Keith body had disintegrated by this time, but there are several evidences that the personal bitterness in many cases had not passed away. At any rate the Assembly followed Lloyd most loyally in his moves against the proprietor and his seeretary.

The best friends of the province were in despair. In this vein Isaac Norris who was now in England writes to James Logan: "Serious and sorrowful reflections upon the present state of poor $\mathrm{Pa}$. have presented themselves and they give a melancholy and discouraging prospect. The ingratitude of the Lieut. Gov. to his friends that had staged themselves to serve him, the disposition and thwarting designs of others, the heightening of parties, the decay of trade, the discredit the country has here, the proprietor's hard circumstances with Ford and his other involvings, his placing all upon that country, and expectation of more from it than it is able or willing to do with other contingencies and the confusions in view make me almost wish I had no obligations there."

Added to this there was a most urgent insistence on the part of the non-Friends on some adequate means of defense. A French privateer landed some sixty men at Hoarkill 


\section{I28 POLITICAL LEADERS OF PENNSYLVANIA}

(Lewes) and plundered it, carrying some citizens away for ransom. It was possible that the same might happen at Philadelphia and there was a clamorous demand as Logan writes against "the absurdity of pretending to govern without applying force in the greater as well as the least degree," that is in general armed defense as well as against a robber. But nothing was done and the province was not disturbed by privateers. Serious remonstrances were however sent to England that the Quakers were unfit to manage a government. The trouble became intense and Isaac Norris wonders "whether it were the worse prospect to hold it (the government) under such difficulties or resign it to men who have no honorable principles."

Yet after all the people lived in peace. Again Logan writes "In this country we have no such settled estates and constant incomes; yet want not the blessings of the necessaries of life; very few things wanting except some luxuries. As for myself I bless the Almighty I want nothing of the useful conveniences but live equal with my neighbors and desire not an abundance."

William Penn was now in the thick of his controversy with the Fords and part of the time was lying in a debtors' prison in England. The troubles in his colony preyed upon him and he was told very plainly that peace could only be secured by the discharge of Evans. Isaac Norris who was in England aiding him in settling affairs with his creditors urged the same, and Penn was finally freed by a compromise on the debts and the promise to appoint a new governor. The province was mortgaged for the debt to a number of his friends to be repaid out of the quit-rents, sale of lands and other receipts of the province, and Edward Shippen, Samuel Carpenter, Richard Hill and James Logan were made commissioners to perform the active duties under the trust. As secretary this all went through the hands of James Logan. 
The new Deputy-Governor, Colonel Charles Gookin, reached Philadelphia in March 1710. He found in session the same hostile assembly that had impeached Log:un and remonstrated to Penn. They showed no signs of any mitigation of their bitterness and immediately began to complain of the actions of the new official. Some of these complaints were trivial but they found a real difference in the frequently recurring question of military defense. The house refused absolutely to endorse the request to furnish 150 men to join in an attack on Canada or to provide any funds for the purpose. They found that the governor had been instructed by Penn to refuse to pass any law not approved by the Council. But that body was simply an advisory body for the governor, not recognized by the charter. This recognition by Penn seemed to give it some governmental power and the house resented the implication, the more so that Logan's influence there was predominant. On the whole the Governor, who was rather testy in disposition, behaved himself at first with judgment and moderation.

Logan now decided that the time had come to strike back at Lloyd in counter charges. But here again some political fencing prevented any open trial and the exact nature of the charges does not appear, but the house, loyal to its Speaker, pronounced then false. Logan then sent back a defiant message to the Assembly which greatly increased their resentment, and they directed that he should be sent to prison. Their right to take this extreme measure was denied by the Governor. Logan was now about ready to earry his ease to England and after some attempt to delay his passage, he got away and in due time was presenting the whole matter to the Proprietor in person.

William Penn never seems to have lost faith in his secretary as the letters between them, saved through the eare 


\section{I30 POLITICAL LEADERS OF PENNSYLVANIA}

and labor of Deborah Norris Logan, abundantly show. These letters betray the zeal and fidelity for his employer's interests which characterized the secretary, as well as the censorious spirit toward opponents which he was continually pouring into Penn's mind. He said what he thought and his views changed with the years. It is unsafe to form historic judgments on the basis alone of certain of his statements, but the whole series, combined with the official records of the Council and Assembly, afford a ground-work for a fairly accurate decision as to the quality of the government of the Quaker province through this first decade of the 18th century.

As a whole one cannot derive much satisfaction from the record. There was too much partisanship, too much selfishness, too much ascription of personal motives, among Friends to answer the ends of Christian courtesy or good government in its best estate.

The Friends that rallied around James Logan felt keenly the difficulties of the Proprietor who had sacrificed so much of time, comfort, and money in his effort to found a commonwealth on the basis of principle, and who, they knew, could have sold out to the Crown at a great relief to himself had he been willing that his colonists should lose something of the liberties they had received by the migration. While he was sacrificing for the settlers, they seemed disposed to deprive him of his just dues in quit-rents and other income needed for the government. On the other hand he could hardly divest himself of a certain feeling of class distinction. His ideal, however much he might keep it down, was a feudal lord, an absentee landlord, dispensing with a generous hand the blessings of liberty and happiness to willing and loyal citizens. Add to this the great dissatisfaction with the personal and political conduct of Deputy-Governor Evans, and the rather haughty and testy spirit of Logan, devoted to his 
duty, and, fearless of opposition as he was, and the friends of Penn were kept the most of the time in a constant posture of defense.

On the other hand the country people who were led by David Lloyd had back of them the instinct for liberty and equality, the inleritance of the English race, just strengthened by the Puritan spirit and the polities of the Commonwealth period. They had a smaller vision than the proprietor's party, and hence were led into the more obvious courses based on present needs which the methods of their leader used to the utmost. That able lawyer, faithful to the patent implications of Quakerism, but, at least during this deeade, hardly possessed by its spirit, played with the prejudices and material interests of the country population at his will. They wanted to live eonsistently their lives of opposition to war and oaths, of striet morality and quiet attention to their farms and meetings. They had a dim instinct of opposition to the eity men of growing fortunes, a very strong protest against inmorality in high places. They did not mean to be disloyal to Penn as their conduct in 1705 made manifest. Had he been with them or sent an acceptable deputy they would have worked out their problems without great friction, but they become suspicious, narrow and partisan, and David Lluyd who knew the value of eivil liberty and honestly wanted it, had an easy task in marshalling the country hosts, sometimes by methods which cannot be fully defended, into lines which as reported by Logan gave deep offense and disappointment to the great-hearted Proprietor.

It must be remembered however that the eonfliets were conflicts of leaders. The great bulk of the people carried on their work on farm or shop, grateful for the liberties they enjoyed, with none of the bitterness of Logan and Lloyd. These divisions never showed themselves in the 


\section{I32 POLITICAL LEADERS OF PENNSYLVANIA}

records of their meetings. At one time Logan seemed to think an ecclesiastical separation partly based on politics probable, but it never came. The quiet of worship and the real goodness which pervaded the rank and file of the membership kept down partisanship and allayed acrid feelings. The writings of traveling ministers and the good advice of the Yearly Meetings indicate the best of feeling and the successful pursuance of the church objects.

The troubles of the Friends as the result of their seruples were bringing many of them to the point where they were beginning to doubt whether they ought to have anything to do with govermment, - a doubt which the success of the following thirty years largely dissipated. We find Isaac Norris in a letter to William Penn writing: "We say our principles are not destructive or repugnant to civil government and will admit freedom of conscience for all, yet it appears to me according to the best scheme I can form from the opinions of many Friends, that to be concerned in government and to hold (maintain) ourselves, we must either be independent or entirely by ourselves . . . and not allow the liberty of others who make conscience to have an oath; . . or be as thou used to express it, 'Dissenters in our own country.'",

The problem of liberty of conscience was being worked out and, amid the confusion of party rancor, people were thinking with fearful hearts that the William Penn ideals might not be possible of achievement. The political upheaval of the next year settled some of these questions at least temporarily.

"Thou used to talk about astral influences. I am not very superstitious though I cannot but take notice how universally and resolutely Friends here were spirited about this election," Isaac Norris writes to James Logan still in England after the election for the Assembly which occurred in 
October, 1710. As soon as they saw that Evans was dismissed and had heard from England of the condition of the Proprietor the provinee as one man returned to its allegiance. An absolutely new Assembly was elected. Lloyd himself was defeated. The strongest men in the province and the best friends of Penn and Logan were returned. Richard Hill became speaker and abundance of good legislation was passed. Compromises were made on both sides. The right to adjourn at pleasure for which Lloyd had fought so vigorously was aceorded, and the judieiary was established by law. Both impeachments were dropped and heard of no more. Supplies were voted liberally for the support of the government and $£ 2000$ for " the Queen’s use" without conditions. The real blessings of the free institutions of Penn were abundantly recognized, and every effort was made to bring up to date legislation which had been postponed by the political turmoil of the preceding three years. The province steadied itself in the face of its problems and privileges and set itself to work out its destiny with cheerful and united effort.

In the midst of this wave of unity Logan returned from England vindicated as far as conditions there would allow, and with no loss of confidence on the part of his employer and his friends. Moreover he brought with him a pathetic appeal from William Penn, then in his 70th year, which he may have helped to frame, and to which his knowledge of the situation had undoubtedly contributed. The composition was however that of Penn and not of Logan. It did not reach the province till after the election but had a profound effect in stimulating the returning loyalty to the Proprietor. It begins:

"My old Friends - It is a mournful consideration and the cause of deep affliction to me that I am forced by the oppressions and disappointments which have fallen to $\mathrm{my}$ 


\section{I34 POLITICAL LEADERS OF PENNSYLVANIA}

share in this life to speak to the people of that Province in language I once hoped I should never have occasion to use. But the many troubles and oppositions I met with from thence oblige me in plainness and freedom to expostulate with you concerning the causes of them."

Then he reviews the liberal principles by which he has been guided, his personal work for the province and his financial losses and contrasts these with the contentions and ingratitude of the settlers. He takes up both the political and personal questions which had separated them. Some are small and can be readily rectified. "It is a certain sign you are strangers to oppression and know nothing but the name, that you so hightly bestow it on matters so inconsiderable." There are other lawyers except the one by whom they have been guided almost exclusively "whom I cannot think so very proper to direct in my affairs," was his suggestion as to David Lloyd. Nevertheless, small or great, he is very willing to adjust them to suit their convenience so far as is consistent with a fair balance of govcrnmental powers. He defends Logan. "From all the charges I have seen or heard of against him I have cause to believe that hatd he been as much in opposition to me as he has been understood to stand for me he might have met with a milder treatment from his persecutors; and to think that any man should be more exposed there on my account and instead of finding favour, meet with enmity for his being engaged in my service is a melancholy consideration." Thus identified with the Proprietor and amply vindicated the secretary could afford to return in triumph to the province. Finally Penn intimates that the conduct of the Assembly might determine whether or not he should sell his interests to the Crown.

This letter was read in all the meetings of Friends and was responded to with an outburst of respect and affection. 
"Sure an overruling hand directed that our thoughts and actions here should be answerable to thine there" writes Isaac Norris.

Both Penn's political and financial troubles were now somewhat alleviated but enough remained to make his retention of the proprietorship a matter of serious misgiving. He could sell his rights as governor to the Crown, retaining his individual property and claims. His situation would then become easy and his family amply provided for. Logan advised this strongly. While Gookin meant well his tactless and unwise assertion of power still made trouble and there seemed no end of such little difficulties. Penn's only hesitation came from the fear that his settlers would suffer in their maintenance of their principles from the demands of the English government. War, civil and religious liberty, oaths, and the treatment of the red men were very vital problems in the new experiment and such arrangements must be made as would secure the colonists against any return of English persecution, against making the Quakers "dissenters in their own country." Penn seems to have thought that this was accomplished. The transfer was arranged and something paid by the government in advance, when on the 4th of 8th Month (October) 1712 his hand became paralyzed in the midst of a letter to Logan. Some months later his wife forwarded the incomplete epistle to the secretary with a postscript from Penn, much of it illegible but closing with the words " $\mathrm{My}$ dear love to all my dear friends."

He lived six years longer, unable to transact business. The bargain with the Crown was annulled, ultimately much to the gain of the family, and Logan's engagement and instructions thereafter came from Hannah Callowhill Penn and her children.

Shortly before the attack the secretary arranged for pay- 


\section{I36 POLITICAL LEADERS OF PENNSYLVANIA}

ment for past services. He writes later "The Proprietor was willing to give me what I would ask for my ten years' service and considering his melancholy circumstances in 1711 I set it only $£ 100$ a year currency, for all manner of services whatever; but told him I could stay in his service no more than two years. But he was seized with an apoplectic fit in less than one year, which tied me down to his business, and vastly as it proved to my loss."

Logan writing in 1714 says that the people are "generally pretty easy, all the factions against the proprietor being over." There were no more Quaker parties in the government but Logan's troubles were not over. Gookin after several years of great harmony with the Assembly became disaffected and got on wrong terms with every one. There was some cause. His meagre salary was frequently unpaid and he was reduced to the necessity of undignified begging in procuring an ordinary existence. The personal loyalty to Penn reawakened by his appeal of 1710 partly passed away when the pecuniary needs of the government seemed to conflict with what he considered his personal rights. A new generation was growing up who did not know him and since his release from active connection with the province were less disposed to join with Norris and Logan in a vigorous assertion of his claims.

First Gookin quarreled with Lloyd (who was in 1715 again speaker) and the Assembly, because there was not a quorum on the day for convening. He afterwards charged Norris and Logan, the former now mayor of Philadelphia, with disloyalty to the Crown. He himself in retracting the charge intimated that he was temporarily deranged, a not improbable suggestion. His Council in 1717 sent a unanimous address to William Penn that he be removed, and Hannah Penn now manager for her husband appointed Sir William Keith as successor. These troubles however did 
not, except in one particular, seriously distract the good legislation of the province and matters were rapidly getting into shape.

This one exception related to oaths. There was nothing on which Friends were more consistently united than in their opposition to the administration and taking of oaths. Lloyd was their great champion but Logan and his friends were with him. Their objection was party biblical, largely their denial of a double standard, one for the court-room and another for the shop and the farm. They demanded that their yea and nay be taken at their face value whenever uttered: they charged that the constant formal and often flippant use of the name of the Deity induced irreverence and profanity. They refused to have anything to do with oaths or to hold any office which necessitated administering them. Largely due to Quaker protests reinforced by imprisonment a form of affirmation not very satisfactory had been substituted in England. But they also recognized that their principle of freedom of conscience, as well as respect for English law, could not force affirmations on dissidents in Pennsylvania. Up to about 1715 by virtue of acts passed by the Assembly matters had gone on quietly and oaths were practically not administered. The English law of that year put out of all official positions, including juries, and out of the witness box, all who did not swear. Now Governor Gookin construed this as applying to the colonies.

In many country districts there were none but Friends and illiterate servants and all judicial proceedings were stopped. In the city it was not much better as Friends held all the important positions and constituted the leadership of the political situation. Lloyd gave his legal influence vigorously to the cause but the governor stood firm in his construction of the law. For two years the province survived without courts and criminals went unpunished. An 


\section{I38 POLI'TICAL LEADERS OF PENNSYLVANIA}

atrocious murder committed in Chester County seemed to make it necessary to do something, and the culprit was condemned to death on the strength of unsworn testimony and by an unsworn jury. Appeal was made to England but Keith, by this time governor, hung the criminal.

We may carry this account ahead of our general narrative. Sir William Keith, a man of great political acuteness, suggested that if the Assembly would adopt the English penal code they might in exchange have their way in the matter of oaths. Lloyd and his friends agreed and in 1718 placed burglary and some dozen erimes on the capital list, in the same act making affirmations and oaths optional with the taker. The form of affirmation included however the phrase "in the presence of Almighty God," to which many Friends objected and in $\mathbf{1 7 2 5}$ this was further modified to make it a simple affirmation. This relieved the taker but as oaths could still be demanded by those without scruples in the matter, there was nothing for the consistent Friend to do but refuse an official position which involved administering them, so that in this respect Friends became "dissenters in their own country." The solution found in 1725 still continues.

The extension of the capital code from Penn's limitation to murder in the first degree to a number of lower forms of crime seems to have met with no opposition from Friends and was continued through all colonial times without protest. Thus John Smith a prominent Friend writes in his diary in 1747, "Was part of the day at the Court of Oyer and Terminer called on purpose to try three villains for a burglary and robbery of the widow Cox at my aecusing which was so clearly proved that the Jury soon found them guilty." And again a day later, "Heard that sentence of death was passed on the poor villains mentioned above."

Better times were coming for the secretary. In 1714 he 
made a happy marriage with Sarah the daughter of Charles Read, a Councillor prominent in public affairs. He engaged in the Indian trade and in commereial ventures which ultimately brought him a considerable fortune. His friends were the most intellectual and most influential citizens of Philadelphia including "wise Samuel Carpenter," Isaae Norris, and Richard Hill, "the three best heads in Pennsylvania," as he says. He himself was their peer in business sagacity and their superior in learning and scholarly interests. The voice of faction among Friends had ceased and England presented after the peace of 1710-12 no elaims for military service for almost 30 years. The oath question was settled. There was litigation over William Penn's Estate but this was confined to England and ultimately resulted in 1726 in confirming the title in the hands of John, Thomas, and Richard Penn, the sons of the second wife. These became warm friends of Logan and fully trusted him, while he returned to them as agent and secretary the same unswerving fidelity which he had aceorded to their father. The great immigration of Germans and Seotch-Irish solved the finaneial difficulty by land sales and quit-rents. Wise legislation placed the government in smooth working order, and a satisfactory system of courts was established. The management of Logan kept the Indians friendly. Taxes were trifling. The average provineial expenditure under Keith's administration was 1500 pounds a year. Laws forbidding the use of molasses and other foreign substances in the manufacture of beer, and requiring that all flour and salted provisions should be up to a standard quality, thus insuring a great foreign trade, stimulated home production, while the immense immigration vastly increased the product of the farms. Peace and liberty were proving their efficacy as agents of prosperity and comfort, enriching alike country farmer and eity trader. 


\section{POLITICAL LEADERS OF PENNSYLVANIA}

There was however much difficulty owing to the scarcity of circulating medium, for the imports still were in great excess of exports, and had to be paid for. Keith suggested a paper issue based on land and plate. But Logan, warned by the unfortunate experiments in other colonies, opposed it vigorously. The bill went through the Assembly however and Logan's opposition had the very desirable effect of making it a conservative measure. Hence the paper never depreciated and greatly increased trade.

An Indian incident of 1722 will illustrate the methods by which peace on the frontiers was maintained. The council was informed that a red man of the Five Nations had been killed in what is now Lancaster County by two whites named Cartledge. James Logan and Colonel French were deputed to ascertain the facts. They called a council of Indians at the place of the murder and had the suspected criminals arrested. Logan made one of his happy speeches, for he was now well versed in Indian psychology, calling attention to the league of friendship made by William Penn and that the league had been rigidly observed by both parties. Only one complaint had been made for forty years. Now a report had come of a murder by a white man, and they had come to condole with the friends of the victim and see that justice be done according to the league of friendship.

Witnesses were then examined by which it appeared that the Indian was setting his traps when the Cartledges came to him to trade. They gave him rum and he persisted in his demand for more till the trader irritated struck him so that he clied. A message was sent to the Senecas in New York with a statement of regret and that the offenders were to be taken to Philadelphia to answer for their fault. After various circumlocutions and conferences and exchanges of wampum belts final word came to Philadelphia as follows: 
"We have well considered all you have spoken and like it well, because it is only the renewing of the former leagues and treaties made between the government of Pennsylvania and the Five Nations, which we always believed we were obliged to keep. And as to the accident of one of our friends being killed by some of your people, which has happened by misfortune and against your will, we say that we are all in peace; we think it hard the persons who killed our friend and brother should suffer and we do in the name of all the Five Nations forgive the offence and desire you will likewise forgive it, and that the men who did it may be released from prison and set at liberty to go whither they please; and we shall esteem that as a mark of regard and friendship for the Five Nitions and as a further confirmation of this treaty."

The Indians on the Brandywine sent a petition to the Assenbly making complaint against the whites for infringement of their fishing rights. They asserted that William Penn had granted them a tract a mile on either side of the Creek, the deed for which had been burned in the cabin in which it was kept. There was no record of such a treaty. The English had settled all over this tract and worse still had built dams which prevented the passage of fish. While the story was based on no legal claims Logan recognized the vitality of Indian tradition, and induced the governor to order that the dams should be constructed so as to allow the fish to pass.

These incidents are illustrations of the management of Indian relations through the first half century of the province under William Penn and James Logan. It is easy to see why there was uninterrupted peace. There is probably no record of Logan's attitude toward the Walking Purchase and the iniquities that followed it, but it maly be assumed to aecord with his other actions.

There is a story that the old chief Wingohocking became so friendly that he offered to change names with Logan. 


\section{I42 POLITICAL LEADERS OF PENNSYLVANIA}

It was not entirely convenient to accept the offer, but the chief must not be antagonized. So Logan replied that he would soon pass away and be forgotten, but the stream, pointing to one which went through his fields, would flow on through all generations, and he would give it the Indian name to be carried down forever. This happy expedient satisfied the Indian who changed his name to Logan and transferred his own to the stream which still perpetuates it.

Twenty years after the Cartledge incident when James Logan was an old man, a chief of the Six Nations expressed his kind regard for him in Indian fashion to the Governor and Council in Philadelphia:

"Brethren we ealled at our old friend James Logan's on our way to the city, and to our grief we found him hid in the bushes and retired through infirmities from the public business. We pressed him to leave his retirement and prevailed with him to assist once more on our account at your council. We hope notwithstanding his age and the effects of a fit of sickness which we understand has hurt his constitution that he may continue a long time to assist this province with his counsels. He is a wise man and a fast friend to the Indians; and we desire when his soul goes to God, you may choose in his room just such another person of the same prudence and ability in counselling and of the same tender disposition and affection for the Indians."

Sir William Keith had proved a popular and politic governor. He had shown Friends a solution of the oath difficulty; had carried through the movement for a paper currency; had suggested many pieces of good legislation; and by his agreeable manners had made a most favorable impression on the people. But after nearly ten years' service he ran up against Logan and his friends in a delicate matter of management. Theoretically the Council had no legal rights in legislation, being only an advisory body for the governor. But he was nevertheless the creature of the Penn 
family who had implicit trust in Logan and who had sent instructions that no measures were to be passed without the consent of the majority of the Council. Keith tried various devices to rid himself of this incumbrance. On the other hand the Council tried to set up an unjustifiable claim that its relations to government were somewhat like those of the House of Lords in England, and held as strictly to their powers as possible. Keith for a time carried on the contest with his usual astuteness, but in 1722 becoming bolder in his methods and feeling sure of popular support, on the plea that Logan had entered on the minutes something that had not officially passed the Council, the governor discharged him from his offices as councillor, secretary and keeper of the great seal. He was thus thrown entirely out of the government.

But he was not of the sort that submit easily to such a dismissal. He sailed to England and returned in a little time with definite instructions from Hannah Penn. Keith was to make at least half his board Quakers and no new members were to be appointed without the consent of those already in. He was to send no verbal or written messages to the Assembly without their consent. He was to reinstate Logan in all his offices, and was threatened with disnissal if he further disobeyed.

This was humiliating enough to a man of such large influence and importance, still more so that it came from the hands of Logan. He decided not to submit and prepared a reply justifying his actions to the Assembly. This brought to his aid the old war-horse David Lloyd, now Chief Justice of the province, who gave his legal advice to the support of the independent powers of the Assembly and the non-interference of the Council. The Assembly backed up their old leader and assured Keith of their gratitude. But they could not prevent his dismissal by Mrs. Penn and when he was 


\section{I44 POLITICAL IEADERS OF PENNSYLVANIA}

himself elected a member of their body and aspired to the speakership he was easily defeated by David Lloyd.

He was succeeded by Patrick Gordon, a wise old man who seemed to harmonize the hitherto conflicting claims of Proprietor and Assembly. For ten years, 1726 to 1736, there was great peace and prosperity. There was a vast influx of foreigners, Palatines from the Rhine Valley and Presbyterians from the north of Ireland, as many as 6000 to 8000 per year. Many were poor, without money even to pay for their passages, and were sold out to service in the Delaware River for a term of years. This supplied abundant labor but the influx was not looked upon with much favor by the Philadelphians. Problems of illiteracy and sanitation demanded much attention. A tax of 40 shillings per head was passed on all aliens imported. The Germans, as a report to the Assembly asserted, "had purchased and honestly paid for their lands, had conducted themselves respectfully towards the government, paid their taxes readily and were a sober and honest people in their religious and civil duties." Yet they would use their own language and lived very much to themselves. The Irish moved to the frontiers and their inconsiderate treatment of the Indians was already beginning to stir up trouble which developed later. It seemed that the colony would soon contain a foreign population. The franchise was however still largely in the hands of the original settlers and their descendants. It was limited to men who owned 50 acres of land or had an income of 50 pounds a year. This was probably the most liberal of all the colonial laws and far more so than those of England; but it tended to continue a literate and hereditary electorate. The Assembly was constituted of 26 members, eight from each of the three original counties of Chester, Philadelphia, and Bucks and two from the city. As these country districts were almost exclusively Friendly a large majority of, and 
frequently all, its members belonged to the governing sect. When new counties were admitted (Lancaster being the first in 1729 ) they were aceorded a smaller representation and this was not inereased as their population grew. This in time constituted a real grievance.

There were no infractions of religious liberty and no theologieal tests for suffrage except such as were imposed by the English Crown. It was a time of great distrust of Roman Catholies on account of their supposed allegiance to the exiled Stuart family and the French interests. St. Joseph's Church had been built in the eity and mass was openly celebrated there contrary to English law. The Council however decided that Pennsylvania was an exception and that all sects were protected by the charter. Legally the position of the Council was probably indefensible but the matter was allowed to rest.

The Friends by this time had outgrown all internal political parties and worked together. They were without question the governing body, and while making no legal diserimination against other religions, by virtue of their personal eharacter and training and their well organized system, maintained an easy leadership. There is no evidence that they used their ecelesiastical order to advance their political schemes, but their close frendships produced the same effeets. How their candidates were selected is not very evident, but probably by an informal meeting of their influential men. An entry of John Smith's diary speaks of such a meeting. To these selections the body of roters seemed to be loyal. A good man in the Assembly was reelected year after year, for thirty years in the cases of George Ashbridge from Chester County and Isaar Norris 2nd from Philadelphic. It was the high water time of Quaker management and they were giving a good account of themselves. The commerce of the colony was develop- 


\section{I46 POLITICAL LEADERS OF PENNSYLVANIA}

ing at a rapid rate increasing threefold during Gordon's administration. The problems were those of development and not of dissension.

In 1731 in succession to David Lloyd, James Logan became Chief Justice of the province which post he held for five years. His most notable achievement was a charge delivered to the Grand Jury in 1736, in which at some length he goes over the functions of government and the duties of juries in keeping public life up to high standards. This was printed in America and England and received much notice.

In 1736 on the death of Gordon and pending the appointment of a successor Logan as President of the Council became nominal head of the government. He accepted the responsibility with great reluctance. "I am now entering my 63rd year," he writes John Penn the eldest of the proprietors, "much weakened in all respects and so circumstanced that I am every way unfit for it; and I now greatly blame myself for submitting to it on the governor's decease. But next in standing to me being Samuel Preston, who is yet more weakened by age and too rigidly strict in his profession for government .. . I was prevailed upon to accept it, in hopes it might hold only for a few months; and if not relieved, as I have said, I must relinquish it, let it fall where it will."

The Council had no legal part in legislation and hence while the Assembly met to advise, no laws were passed for two years, because there was no governor empowered to sign them. Logan, now the chief man of the colony, had charge of all executive duties. The most important of these related to the quarrel with the governor of Maryland over the still undetermined boundary line. A "war" between two sheriffs' posses resulted in one man being killed on each side and a number being placed in jail. This might 
have developed further, but an order from the King was sent over which resulted in a temporary peace and the release of all prisoners. No lands were to be granted by either province in the disputed territory till further orders.

The great speech of Andrew Hamilton, the first lawyer of the colony, not a Friend, is the best testimony to the happy conditions in 1739 when he gave up the speakership.

Logan desired that John Penn should succeed to the governorship. He distruster Thomas's ability to get along with the people. "If it is so ordered," he writes John, "I shall very heartily wish it may prove to his own and all your satisfaction; yet I have too much reason to doubt of it. An open freedom and plainness, or an effectual appearance of it I take to be absolutely necessary to a governor."

But George Thomas was appointed in 1738. He was not a Quaker and did not understand them. There would have been trouble in ordinary times but the Spanish War broke out a year later and the demands of England, unwisely pressed by him upon the Assembly, created the first friction due to a martial cause since 1712 . The Friends by this time had settled down into the policy of refusal to force any one to fight, Quaker or non-Quaker, or to levy taxes ostensibly for war purposes. They would not interfere with voluntary enlistments, and they would vote money "for the King's use" even when they knew that some of it would go for martial purposes. Governor Thomas misreported them to England and proposed that they should be kept out of government by the requirement of an official oath. He declined to sign bills because they did not embrace military appropriations and because they did not raise the money as he desired, and they opposed him by refusing him a salary. The proprietors were now on his side and the military spirit of the non-Quakers of the city was rising. The Germans who loved neither taxes nor war 


\section{I48 POLITICAL LEADERS OF PENNSYLVANIA}

voted for their friends and the Assembly was steadily supported by the electors.

The contest is explained elsewhere. ${ }^{1}$ We will here confine ourselves to James Logan's part. He had not ehanged his views on the morality of defensive war since he came over with William Penn in 1699. Up to this time there had seemed no occasion to diverge openly from the stand taken by other Friends. Now the issue was more clearly drawn and in 1741 he addressed a letter to the Yearly Meeting. In this he admits that the unlawfulness of all war according to Christian standards is a well-understood principle of Friends and always has been. Nevertheless as all government is founded on force there are conditions when this force must be drilled and armed. While Friends trust that having done their duty, by means which they consider moral, Providence will protect them, they do not observe Christ's other precepts but lay up treasures on earth in which they have been so successful that the province would now be a choice prey for an invader. Only one-third of the people are Friends and others are clamoring for defense, and finally he urges that those who for conscience' sake cannot join to protect the province should decline to be candidates for official position. The paper was referred to a committee which reported that it related to governmental matters and was not suitable to be read in their meeting.

A letter from Richard Peters to John Penn says that when the report of the committee was presented Robert Strettell ${ }^{2}$ alone in the meeting stated that owing to the importance of their old member, whose life evinced his attachment to the Society, the refusal to read the letter would alienate himself and English Friends, but someone plucked

1 See Isaac Norris and John Kinsey.

${ }^{2} \mathrm{~A}$ few years later Robert Strettell was disowned for arming his ship. 
him by the eaat and told him "Sit thee down, Robert, thou art single (alone) in this matter."

The matter produced some diseussion. It was pointed out that it was not the fact of foree but the methods of force, that was objected to and that the police agent used his for the protection not the destruction of Society, and did not engage in the eruelties attendant on warfare. That the Friends did not represent the whole provinee was answered in the next election by returning the old house, even from districts not much inhabited by Friends. "In the most remote eounty of this province," says a Meeting report " at the last eleetion all the representatives returned to serve in the Assembly were of our Society; and though those in the opposition to Friends were very active yet of 1150 freeholders that voted (in which there were not above 20 Friends) they could prevail with searce 200 to join them."

James Logan was also out of sympathy with Friends in the matter of lotteries. For some unexplained reason they had got about a century ahead of general publie sentiment in opposing them and had gone so far as to disown members who bought tickets or managed a raffle. Since about 1720 their utterances were very definite and later, while other bodies were building universities and churches, court houses and jails and public improvements in general from their proceeds, they remained aloof. In 1747 Logan joined with Benjamin Franklin and others in establishing a great lottery from the proceeds of which a battery was to be erected on the Delaware River for defense, and he directed that any profits assigned to him should go directly to the support of the battery.

The last deeade of his life was spent at Stenton, where he exereised boundless hospitality, engaged in classical and scientifie studies and writings, and was consulted on publie affairs. In 1729 he had a fall which broke his thigh and made him a eripple for the rest of his life. 


\section{I50 POLITICAL LEADERS OF PENNSYLVANIA}

His residence, the best specimen of a colonial home still standing, was built in 1728 on his tract of 500 acres near what is now Wayne Junction on the Philadelphia and Reading Railroad. In the main room of the second story, surrounded by his books he spent his time, the grand old man of the colony, respected by all. While differing from his coreligionists on certain ethical matters and taking but little part in church affairs, he had great sympathy with their spiritual attitude in all religious concerns. His family, more Friendly than himself, retained a close association with the leading Friends of the city and formed a part of that delightful society of religious and intellectual souls so pleasantly described by John Smith.

Outside of his denomination he had the hearty respect of all. Benjamin Franklin looked up to him for advice and aid, which was not very generously reciprocated. He was a leading factor in founding the school which afterwards developed into the University of Pennsylvania, and was Overseer of the "Public Schools" founded by the Charter of William Penn. To him repaired the men responsible for the affairs of the province to consult concerning legislation and measures of finance and management, for his most intimate knowledge of all the details of the history of the province and his acquaintance with the Penn family, together with his steady judgment made him an unrivalled authority in all colonial concerns. The sons of William Penn trusted him as implicitly as did their father and he gave them good advice with a free hand. His own success in trade made him independent of any financial payments from them, which suited their rather penurious habits. No charge of misappropriation or cupidity was ever made against him, indeed his services to William Penn were ever generous. Indians by the hundreds for days at a time camped on his place, in grounds especially set apart for 
them, to receive his advice and largesses. Stenton was a center of the intellectual, social and political life of the city.

His intellectual interests were varied. He conducted experiments on the fertilization of plants and announced results verified by modern science. These were published in Latin in Leyden and London. He investigated and wrote upon the angular appearance of lightning and the eause of the apparent increase of sun and moon near the horizon. When Thomas Godfrey was working out his trade as painter and glazier at Stenton, the idea which afterwards developed into the sextant for finding latitude at sea occurred to him. Logan wrote this up for the Royal Society and elsewhere, but the reward for the discovery was given to Hadley. Other scientific publications in Latin followed at intervals. Linnæus in recognition of his botanical knowledge named an order of trees and shrubs the Loganacece.

But the Latin Classics constituted his favorite study and his most distinguished publication was his translation of Cicero's De Senectute, which was printed by Franklin.

His long correspondence with his old-time rival but afterwards fast friend Thomas Story has been printed. Thomas Story was a much esteemed minister among Friends who after fourteen years spent in Pennsylvania moved to England where he was closely associated with William Penn in his later years and lived to an old age. The letters relate to many scientific, philosophical and religious subjects, indicating serious study on the part of both. It is interesting to note a statement of Thomas Story, written in 1738. "I spent some months at Scarborough, attending the meetings, at whose high cliffs and the great variety of strata therein, and their present positions I further learned and was confirmed in some things; and that the earth is of much older date as to the beginning of it than the time assigned in the 


\section{I52 POLITICAL LEADERS OF PENNSYLVANIA}

Holy Scriptures, as commonly understood, which is suited to the common capacities of the human kind, as to five days progressive work; by which I understand certain long and competent periods of time and not natural days." This may have been the beginning of the attempted harmony of Genesis and Geology.

James Logan spent much time and money in collecting the most scholarly library, certainly in the province, possibly in America. It was his regret as he writes Thomas Story " that my considerable collection of Greek and Roman authors, with others in various languages will not find an heir in my family to use them when I have gone." Some time before his death he determined to give them to the city as the nucleus of a public library, and in his will, written two years before he died, he says:

"In my library which I have left to the city of Philadelphia for the facilitating and advancement of classical learning are about one hundred authors in folio all in Greek with mostly their versions; all the Roman classies without exception; all the old Greek mathematicians, viz., Archimedes, Euclid and Ptolemy. . . Besides these are many of the most valuable Latin authors, and a great number of modern mathematicians, with all the three editions of Newton, Dr. Halley, Wallis, etc." He bequeathed this library of 3000 volumes together with an endowment for its increase and the salary of the librarian to the city of Philadelphia. It formed the Loganian Library, which later was included in the Philadelphia Library.

The annalist Watson says, "James Logan was tall and well-proportioned with a graceful yet grave demeanor. $\mathrm{He}$ had a good complexion and was quite florid even in old age; nor did his hair which was brown turn grey in the decline of life, nor his eyes require spectacles. According to the custom of the times he wore a powdered wig. His whole 
demeanor was dignified so as to abash impertinence; yet he was kind and strictly just in all the duties of acquaintance and society."

William Black, a Virginia visitor at Stenton, gives a somewhat different story. "I was very much surprised at the appearance of so charming a woman (his daughter Hannah) where the seeming moroseness and goutified Father's appearance promised no such beauty, though it must be allowed the man seemed to have some remains of a handsome enough person and a complection beyond his years for he was turned 70."

He died October 31st, 1751, having just entered his 77th year, having for a half century placed his impress deeply on the history of Pennsylvania.

James Logan had seven children, three of whom died young. Sarah Logan in 1739 married Isaac Norris, the Speaker, of whom James Logan says that he was the most learned man in the colony except Richard Peters, the Rector of Christ Church. Their daughter Mary married John Dickinson.

William Logan was sent to England under the care of his uncle Dr. William Logan of Bristol to be educated. He became a member of the Council, succeeded his father in care of the Penn estates, and was the herr to Stenton. As Councillor he stood out alone in $\mathbf{1 7 5 6}$ in opposition to a declaration of war against the Indians. His life indicates a closer association with the Friends and more complete sympathy with their moral positions than his father. His son was Dr. George Logan, a leader in state affairs after the Revolution, a student of agriculture, a Senator of the United States, a lover of peace. When in the closing years of the century there was a prospect of a French war, he went on an unofficial visit to Talleyrand and thought that he had large influence in averting it. But Congress passed the "Logan 


\section{I54 POLITICAL LEADERS OF PENNSYLVANIA}

Act" which made such interference illegal and punishable. Notwithstanding he tried again a few years later with England but with less success, for the War of 1812 followed. His wife was the accomplished Deborah Norris, niece of the Speaker, to whom all Pennsylvania historians are vastly indebted for the preservation and copying of thousands of pages of Logan Manuscripts. These covering the time for ten years after 1701 are published as "The Penn and Logan Correspondence." She and her husband made Stenton the center of the best life of the republic. Washington, Jefferson, Franklin, Randolph and many other leading statesmen during the days when Philadelphia was the capital city were entertained with elegant hospitality and the best of Quaker society. Their son Albanus Logan married the daughter of John Dickinson.

Hannah Logan married John Smith who kept the Diary ${ }^{1}$ which gives such an interesting insight into the life of the Quaker group which before the war led the colony in its politics and social life. She became a minister. Her hand was desired by Charles Norris, brother of the Speaker, later the father of Deborah Norris Logan, and the two families lost much of their intimacy on account of John Smith's success.

James Logan Jr. left no children.

When to this complicated family relationship is added the fact that Richard Hill, Samuel Preston and Isaac Norris all married daughters of Thomas Lloyd, that Israel Pemberton Sr. married a sister of the wife of James Logan and their son James a granddaughter of Thomas Lloyd, it will be seen how closely associated by family ties were nearly all the leading men of the "Quaker governing class," a class of which the founders were Thomas Lloyd and James Logan.

${ }^{1}$ See Hannah Logan's Courtship, well edited by Albert Cook Myers, 1904. 


\section{JAMES LOGAN}

I55

After William Penn, the only two prominent men mentioned in these pages not nearly related to the others were David Lloyd and John Kinsey. 


\section{JOHN KINSEY}

After William Penn, no Colonial Quaker had the absolute confidence of Friends in church affairs, and at the same time the strong leadership in the state to the extent possessed by John Kinsey. During the last decade of his rather short life he was the clerk of the Yearly Meeting and its most responsible and influential member. He was also the Chief Justice of the Supreme Court of the Provinee, Speaker of the Assembly and the undoubted leader of his party in political management. By this time the factions within the Society had practically disappeared. It was one loyal united body in both state and chureh. The differences which separated Thomas Lloyd and George Keith and later David Lloyd and James Logan were no longer existent. New issues were soon to arise but when John Kinsey came most prominently before the people, there was this calm which had been cemented by about thirty years of peace and prosperity, after the political upheaval of 1710. During this time the memory of the great Founder had grown more and more in the esteem of his people. His government was established in popular regard as a model of liberality and wisdom. His words were quoted and his example pointed to, in settling the problems which arose.

John Kinsey's grandfather, John Kinsey, was a member of the little band which settled Burlington in 1677. He clied a few days after his landing at the Swedish Settlement of Shackamaxon. His standing may be estimated by the fact that he was one of the Commissioners sent by the proprietors of West Jersey to guard their interests. His son ${ }_{15} 6$ 
John Kinsey the second was a prominent lawyer. In 1716 he was elected to the legislature of New Jersey, of which he was for several years the Speaker. He was also an active and acceptable minister among Friends, traveling extensively through the colonies.

John Kinsey the third had therefore an inleritance of legal and ecelesiastical faculty which he greatly developed in himself. At the same time he had the Quaker discipline of his youth, and a religious tendeney in his early days which steadied and utilized his great powers to a life devoted to publie service.

He was born in Burlington in 1693 . He studied law, was elected to the Assembly of New Jersey and became its speaker as the successor to his father. There are too few records of his public life and still less of his private to enable us to fill up this bare recital.

The first we hear of him in Philadelplia is in 1725 when he came to plead a case in court before Governor William Keith. He began to speak with his hat on. The governor who should have better informed himself as to Quaker scruples ordered him to take it off. He refused stating that he was acting from conscientious motives. The governor ordered the court officers to remove it and the incident seemed elosed.

But to the Quarterly Meeting it was too vital a matter to be dropped in this way. It was an attate upon their religious liberty as they deemed it and they sent a formal protest to the governor.

"There is no people more willing than the Friends to pay all due regards to their superiors, to offer all honor to the courts of justice, and in every way consistent with their religious persuasions to pay all deference to their government and king; but when our 'onception of an individual's personal liberty is trespassed upon, we have openly and firmly borne our testimony against it in all countries and places where our lots have fallen." 


\section{I58 POLITICAL LEADERS OF PENNSYLVANIA}

Keith was a politic man determined to get along with every one. He could not afford to contest a little point like this with a people so strong in numbers and in influence as the Friends then were and the following entry is found in the records of the court.

"On consideration of the humble address presented to the Governor this day, read in open court, from the Quarterly Meeting of the people called Quakers, for the city and county of Philadelphia, it is ordered that the said address be filed with the register, and that it be made a standing rule of the Court of Chancery for the Province of Pennsylvania, in all time to come, that any person whatsoever, professing himself to be one of the people called Quakers, may and shall be admitted, if they think fit, to speak, or otherwise officiate, and apply themselves decently unto the said courts without being obliged to observe the usual ceremony of uncovering their heads, by having their hats taken off; and such privilege hereby ordered and granted the people called Quakers shall at no time hereafter be understood or interpreted as any contempt or neglect of the said court, but shall be taken only as an act of conscientious liberty, of right appertaining to the religious persuasion of the said people, and agreeable to their practices in all the civil affairs of life."

To understand why the good Friends of the day made so much of this question of the hat, we must know the conditions of the times. During the 17 th century men were accustomed to wear a head covering in the house as well as outside. They took it off only as an honor accorded to persons in superior station, and expected those of lower rank to take theirs off to themselves. The regicide judges refused to uncover their heads when they tried King Charles and of course he refused to recognize their standing by uncovering his. A century later at the outbreak of the French Revolution the popular Assembly insisted on wearing their hats in the presence of the nobility, as a testimony to their 
equality. The sturdy Puritanism of the early Friends disposed of the matter once for all, by uncovering to no one save God, neither to King nor Magistrate, Priest nor Judge. Bitterly they suffered for this testimony to democracy. They went to jail for months at the command of angry judges. William Penn wore his hat before King Charles II and the pleasant monarch, remarking that it was not customary in that presence for more than one to remain covered, took off his own. Under all circumstances they stood by their convictions, taking all that came of imprisonment, contempt or ridicule.

It was in 1725 too near this time for the cause to be given away in a Quaker Province, governed by the sons of those who had suffered in England and the meetings unanimously accepted the challenge. Afterwards no Quaker lawyer or witness was required to remove his hat during colonial days.

Joln Kinsey moved to Philadelphia in 1730 at the age of 37 and the same year was made clerk of Philadelphia Yearly Meeting. He was the strong and useful man of the body and held the place till his death 20 years later.

The records of the meeting for these twenty years are full of John Kinsey's work. His name was scarcely ever absent from any important committee. The literary work of Friends of this time, including the London Epistles, the collection of minutes for the new discipline, the epistles to subordinate meetings, was very largely done by him. During most of the time he was engaged in gathering materials for writing a history of the early days of the province, which material afterwards passed into the hands of Samuel Smith. He was the medium through whom the decisions of the meeting were conveyed to the public, as, note for instance, the following minute of 1738 :

"John Kinsey was ordered to draw an advertisement to be printed in the newspapers of Philadelphia, in order to 
inform all whom it may concern that the book lately published by Benjamin Lay was not published by approbation of Friends; that he is not in unity with us, and that his book contains false charges as well against particular persons of our Society as against Friends in general."

Equally prompt was the State of Pennsylvania to demand his services. On the 20th of January, 1731, the sheriff asked admittance to the Assembly with the message: "In pursuance of a writ of the said sheriff, directed by the honorable the governor of the Province, John Kinsey, Gentleman, the day and year above mentioned was elected a representative in the Legislature to serve in the General Assembly of Pennsylvania this present year, in room of David Potts, ${ }^{1}$ lately deceased." On the next day John Kinsey took his seat which he held, with one slight intermission, to his death and after 1739 was Speaker.

As with the Meeting so with the Legislature John Kinsey immediately became the important member, drawing up bills and addresses to the Governor, acting on committees, as trustee of public funds and real estate, as witness that the great seal was properly attached to laws and wherever good sense and legal training could serve the public interests. For several years he was in addition Attorney-General of the Province.

So matters went on till 1739 when Andrew Hamilton resigned the Speakership, tired of its responsibilities and duties, and his faithful and unrewarded attention to the building of the State House. He had handed in his final accounts, and made his great farewell speech, perhaps the best résumé of Pennsylvania Colonial conditions ever given. There was no doubt that John Kinsey should be his successor. velt.

${ }^{1}$ David Potts was a Friend and an ancestor of Theodore Roose- 
On Oetober 15, 1739 the Assembly met and "by a majority vote" made Joln Kinsey Speaker. The same day they presented him to the Governor, George Thomas, an appointee of the Penn Family, who expressed in the formal way his satisfaction with their ehoiee. He then made the usual requests of the Governor " that the House might have ready access to him at all reasonable times when the public business should require it: that they might enjoy freedom of speech in all their propositions and debates: that the members might be exempted from arrest during the sittings of the Assembly: that the Governor should give no ear to reports touehing debates in the House till matters debated on passed into resolves; and that the Speaker's inadvertent mistakes might be excused. All of which he had requested as the just rights of the Freemen of Pennsylvania: and the Governor was pleased to assure the House that they should be protected in the full use and exereise of the same."

This little list of legislative privileges represented the gains made in the years by the Quaker Assembly, in seeuring the independence of the people's representatives from eneroachment of the Proprietors and Governor. They were not likely to lose any of it under John Kinsey's vigorous leadership.

While they did not know it at the time the easy days of Quaker control were about at an end. They were to struggle along in the midst of wars and rumors of wars for some seventeen years longer, but against an ever inereasing opposition from the Proprietors on one side and the militant portion of the population on the other. While John Kinsey was alive they fought the battle successfully in the legislative halls and at the polls. The eontest began on the day following the ehoice of John Kinsey as Speaker.

About the same time that John Kinsey took up the Speakership, George Thomas was made Lieutenant-Gov- 
ernor under the Penns. He knew very little about the character of the people whom he came from the West Indies to govern, but he was a man of ability and resources. If he had been appointed a few years earlier in the times of peace he might have quietly adjusted himself to the conditions; but, unfortunately, Spain and England, as a result of differences centering in the West Indies, concluded to have a war, and Thomas was keen to support his royal master. The two men, Kinsey and Thomas, were pitted against each other as the leaders of the contest which was to follow. Whether we consider skill in disputations or in political management, the end of the struggle did not find the Quaker leader at any disadvantage.

The contest began when, in October, 1739, Governor Thomas sent a message to the Assembly, suggesting that they make an appropriation to protect the province against attack and assist the king. The Assembly took the matter into serious consideration, and explained in a somewhat lengthy preface that they were all loyal subjects, lovers of religious liberty, and that one of the principal motives which had brought them and their ancestors to the Province was the full enjoyment of liberty of conscience which was granted to them by their great charter, and which the proprietor had pledged himself and his successors " according to the true intent and meaning thereof, should be kept and remain without any alterations inviolably forever." And then they add, "It is not unknown most of them were of the people called Quakers, and principaled against bearing arms in any case whatsoever." They admit that the circumstances have changed, and that a great many who have come in since think it to be their duty to fight in defense of their country, families and estates. These also have the same right of liberty of conscience with themselves. They do not condemn the use of arms in others, but they ob- 
ject to any law which would compel a man to bear arms against his conscience; and they add that a law which forces other people to bear arms and relieves the Quakers would be inconsistent and partial. Then they make a suggestion to the Governor, which, if he had been wise, he would have adopted and dropped the matter. They point out that the Charter gave him ample authority to raise a troop himself, and that they did not propose to interfere with his actions in this respect, provided he did not trample upon anyone's conscience. 'The clause of the Charter granting this authority, which William Penn accepted, it may be interesting to note:

"To the Proprietor aforesaid, his Heirs and Assigns, by themselves or their Captains, or other of their Officers, to levy, muster, and train all sorts of Men of what Condition soever or wheresoever born in the said Province of Pennsylvania for the time being, and to make Warr and to pursue the Enemies and Robbrs aforesaid as well by Sea as by Land, even without the Limits of the said Province, and by God's Assistance to vanquish and take them, and being taken to put them to Death by the Law of Warr, or to save them at their Pleasure; and to do all, and every other thing which unto the Charge and Office of a Captain General of an Army belongeth, or hath accustomed to belong, as fully and freely as any Captain General of an Army hath ever had the same."

They wound up their address by the pious reflection:

"Not doubting but that Wee shall share in that Protection Our Gracious Sovereign denys not even to the meanest of his Subjects; And having at the same time a due dependence on that Power which not only calms the raging Waves of the Sea, but sets Limits beyond which they cannot pass; And remembering the Words of the sacred Text, That 'Except the Lord keep the City the Watchman waketh but in vain." 


\section{I64 POLITICAL LEADERS OF PENNSYLVANIA}

We find in this paper several interesting indications of the state of feeling among Friends on the subject of war at this date. One was that they were unequivocally opposed to all war under all circumstances; another, that they had no words of condemnation for those who from good motives thought and acted differently, and thirdly, that if they did their duty their reliance was upon a divine Providence who would order the matter aright.

The Governor was not disposed to recede from the contest. In an epistle equally lengthy he called their attention to the fact that they were representatives of the whole people; that he had no right to look into their personal religious persuasions, but that it was their duty as representatives to protect a rich Province from invaders. He did not wish to infringe any of their consciences, nor to introduce persecution, for he himself was a great friend of liberty. "But," he sail, " as the world is now eircumstanced, no purity of heart or set of religious principles will protect us from the enemy." The Assembly had recognized this in the institution of courts and juries. He told them that they would condemn "little rogues" to death for breaking into their houses and yet they would not use similar means on a larger scale for meeting the more organized attacks upon their property. He had not been unaware of the privileges granted to him by the Charter, and the very fact that William Penn was willing to accept the powers of a CaptainGeneral under this Charter indicated his opinions as to the necessity of bearing arms in defense of his government. Then he puts in a little attack at their trusting in Providence and unwillingness to exert themselves. He says:

"Every Man that acknowledges the Superintendence of one Supreme Being in the Affairs of the World, must be sensible that without His Blessing all we do will come to nothing; and yet we build, we plant, we sow, and we send Ships 
to Sea, concluding that these are necessary means for accomplishing the Ends desired. But that we should do all these, and at the same time expect that God shall fight our Battles, without preparing ourselves the necessary means for our Defence, I confess can be no more reconciled to my understanding than that Because the Lord stills the raging Waves of the Sea, the Seaman may therefore leave the Sails of the Ship standing, and go to sleep in a storm; Or that Watchmen are therefore unnecessary, because Except the Lord keep the City the Watchmen waketh but in vain."

The Assembly returned to the attack, and article by article, replied to the Governor's address. They showed that their position inland from the sea, protected by friendly colonies to the north, east and south, made them in no danger of being attacked. Consequently the Governor's argument for the need of defense had no bearing on the case. They will not admit the justice of the comparison between the "little rogue" and the "great invaders." Their argument is this:

"And yet it is Easy to discover the Difference between killing a Soldier, figliting (perhaps) in Obedience to the Commands of his Sovereign, and who may, possibly, think himself in the Discharge of his Duty, and executing a Burglar who broke into our House, plundered us of our Goods, and perhaps would have murdered too, if he could not otherwise have accomplished his Ends, who must know at the Time of the Commission of the Fact, It was a violation of Laws human and divine, and that he thereby justly rendered himself obnoxious to the Punishment which ensued."

They would evidently have made a stronger case if their attitude toward eapital punishment had permitted them to say something more of the sacredness of human life; but, having just enacted laws inflicting the penalty of death for burglary, rape, counterfeiting and other crines, they could 
hardly say that they had any objection to the taking of life per se. They believe, however, that an Almighty Power does superintend the government of the world, and that $\mathrm{He}$ will protect the principles of religion which are agreeable to His will. As to William Penn's being a believer in war, they state, with some sarcasm, that they probably know as much about his opinions as the Governor does. They say, "he not only professed himself a Quaker, and wrote in their favor, but particularly against war and fighting." As to the comparison between the preparation for storms at sea and harvests on land, and self-defense in the time of danger, their argument is:

"By a law almost as old as the Creation, Building, Planting, Sowing, and other parts of Agriculture became necessary for the Sustenance of Life; And so to those who would traffick in Parts beyond the Seas, Ships and Seamen were requisite; the Nature of whose undertaking obliged them to Industry in discharge of their Duty as well as for their own Safety, and not attended with any Injury to others; But because we may lawfully build, plant, sow, or send Ships to Sea, or that because it is necessary for Seamen to take care of a Ship in a storm, that therefore it is not inconsistent with Christianity to defend ourselves at the Expense of the Lives of our Fellow-Creatures, tho' our Enemies, is not equally evident to us; And yet if others think the Arguments forcible, such have their Liberty."

The Governor, in a couple of days, returned to the attack. He reproved them for their acrimony, which, he says, he little expected from men of their principles, and declares he will not engage in the discussion in that spirit. $\mathrm{He}$ thanks them sarcastically for their description of the geography of the Province, which he intimates he is not entirely unacquainted with. And then he again takes up the question of the burglar where he evidently thinks he has a point: 
"If a Burglar acts contrary to the Laws of Christianity and of the land in breaking open your Houses, and by those Laws you are justified in putting him to Death; and if a soldier acts contrary to the Laws of Christianity (as he does according to your own principles) and the Laws of Nations, in plundering your Houses and murdering your Families, it will be difficult to shew why you may not as justly put the latter to Death as the former. The Will of the Prince, or the mistake of the Soldier, can have nothing to do in determining the moral Good or Evil of the Action."

He points to their early appropriation of money for the King's use in manifest response to a demand for war funds, and admitting that he does not know very much about William Penn's writings, he adds:

"As Actions are the best Evidences of a Man's Thoughts, your first Proprietor's acceptance of a Military Charge, his devolving it upon his Lieutenants, and his Commission to a Person to command a Fort at Newcastle, which I have under his own Hand writing, are sufficient Proofs to me of his Opinion; and tho' I have a very high Regard for that Gentleman's character, render it altogether unnecessary to examine his Writings, if he has wrote on that subject."

He replies in conclusion:

"For I believe it will be still thought as little consistent with reason to expect we shall be protected from an enemy without preparing the necessary Means for Defence, as it would be to expect Grain without Sowing or Fruit without Planting, and so in other Instances."

The Assembly contented itself with a general reply to this, stating that they had no delight in controversy; that they did not believe the Province was in danger; that the early appropriations of money for warlike purposes did not prove their utility; that they were steadfastly loyal to King George, and that on the basis of these well-known principles 


\section{I68 POLITICAL LEADERS OF PENNSYLVANIA}

had always enjoyed the protection of the Crown, and that the Province would receive no ill effects from their lack of legislation.

In the main their argument was that fighting being immoral in itseli was very unlike the preparation for a storm at sea and that they could not do it even for a good cause.

Then the Governor replies in a final argument, and asks the question which has never been answered: "If your principles will not allow you to pass a bill for establishing a militia, if they will not allow you to secure the navigation of a river by building a fort, if they will not allow you to provide armies for the defence of the inhabitants, if they will not allow you to raise men for his Majesty's service for distressing an insolent enemy, is it calumny to say your principles are inconsistent with the ends of government?"

There was a veiled irony in many of the Assembly's replies which presumably came from the pen of John Kinsey, and which delighted the men who, in the coffee-houses of Philadelphia, followed the controversy with great interest - as, for instance, when they said that the Province had prospered under the Quaker management before Governor Thomas had anything to do with it, and probably would in the future; "though some Governors have been as uneasy and as willing and as ready to find fault and suggest dangers as himself." Or again, as the election approached, "If we have committed any mistakes, the time draws near in which our constituents, if they think it necessary, may amend their choice, and the time also draws nigh in which your (councillors' and governor's) mistakes may be amended by a succeeding Governor. Permit us to congratulate our country on both."

During the course of the controversy, parties were gradually forming, and this thrust and counterthrust of arguments were simply appeals to the constituents; for there 
were no editorial comments in the seanty papers of those days by which public opinion was influenced. The arguments were passed around by word of mouth or by written manuscript, and in many a coffee house or country tavern, and doubtless also on the steps of the meeting houses after the assembly was dismissed, they were repeated and illustrated with ever-increasing emphasis.

That the Governor's threat to drive Friends from the Assembly was not purely an empty one, is shown by a letter which he wrote to the English Government, eonsiderably misrepresenting the situation, and recommending that all Quakers be made ineligible to official situations. This was intended to be private, but a friend of the Assembly got possession of it in England, and sent a copy to Philadelphia. Great was the wrath of the men who for half a century had felt themselves responsible for the conduct of affairs, and under whose management had developed the most thriving Province of the new world.

The "Gentlemen's Party," which was the title that the Governor's friends took to themselves, also girded themselves for the eontest, and in the fall election of $\mathbf{1 7 4 2}$ there was a great street fight in Philadelphia, the actual participants of which were a number of sailors for the Gentlemen's Party and a bunch of hard-fisted Germans for the Quakers. It is unnecessary to add that the Quakers triumphed both in the street contest and at the polls, and rather increased than diminished their great majority in the Assembly.

They also struck the Governor at another point. He was promised a salary by the Penns, whose agent he was, but this salary had to be voted by the Assembly. During the stringency of the contest the Assembly always forgot to place such an item in their appropriation bills, and for several years he nursed his wrath in poverty. But being now beaten at the polls, he showed signs of yielding. He signed a bill 


\section{I70 POLITICAL LEADERS OF PENNSYLVANIA}

which he had hitherto opposed, and a little salary was granted him. He signed another and the Assembly began to feel still more generous. Finally he gave way altogether, and all his arrears were paid. He got along very pleasantly with the Assembly during the rest of his official career. He was completely tamed.

The net results of the contest were a large increase of liberty for the people of Pennsylvania; the perfect maintenance of their anti-martial principles; the defeat of the Gentleman's Party at their own political game; the increasing strength among the people of the Quaker leaders in government; the triumph of economy and simplicity in the management of public affairs. John Kinsey's letters, full on the one hand of pious reflection, and on the other, of adroit political argument, had carried the day. The "Country Party," as his friends were generally called, had become supreme. One by one the claims of the proprietors - who were now farning Pennsylvania for what they could get from it, in a very different spirit from that of their highminded father - were cut down. The possibility of gaining political ends without the sacrifice of principles was beginning to answer the taunt of Governor Thomas that their theories were inconsistent with government. In 1747 Benjamin Franklin writes of the Friends as "that wealthy and powerful body of people who have ever since the war governed our elections and filled almost every seat in the Assembly." Evidently they were good politicians, and the contest with the Governor had resulted in a strengthening of their lines.

The Spanish War did not last long, but others came. The Governor used his authority as Captain-General to organize a voluntary force said by Franklin to consist of 10,000 men. On this the Assembly took no action. The Assembly frequently reminded the Governor that they were unable to 
vote any money for warlike purposes, and personally would contribute nothing in the way of service, but that they were loyal subjects of the King and acknowledged their obligations to aid in his government. The effect of this course was to save their fellow-members in the Province from compulsory military service, and from direct war taxes. They thus shielded the consciences of sensitive Friends, preserved their charter from Court attack, broke down the worst evils of proprietary pretensions, and secured large additions of liberty. Whether or not the partial sacrifice of principle, if so it was, was too high a price for these advantages, was differently decided in those days, and will be to-day. An unbending course would have but hastened the inevitable crisis.

Matters went on in this unsettled way through the remaining years of John Kinsey's Speakership. The Assembly would appropriate money "for the King's use " and the King through the Governor would use it for warlike purposes, as all taxes in all lands have been used. If there were a direct tax asked for a definite military purpose it would be refused. Up to 1750 the Friends under Kinsey's leadership were reasonably consistent. Afterwards the difficulties increased and after 1756 they gave it up and refused membership in the Assembly.

On the death of David Lloyd in 1731 the position of Chief Justice of the Supreme Court was offered to Isaac Norris the elder who declined. James Logan was then appointed and he held the post till 1739. Jeremiah Langhorne followed him till 1743 when John Kinsey was appointed and with him the line of Quaker Chief Justices ended. There is so little one can glean from the records of the doings of any of these men in this capacity that the history of the court and the competency of the Justices is largely a matter of inference. Logan never had a serious legal education 


\section{POLITICAL LEADERS OF PENNSYLVANIA}

and probably this was not demanded by the times. Kinsey. was a lawyer of great learning, skill and probity and the honor of the court doubtless did not suffer in his hands.

During these years he performed other public services of value. The continuous discussion with Maryland over the Boundary Line developed finally into a "war." A militia captain and surveyor in the interests of Lord Baltimore and Governor Ogle drew around him a band of ruffians and in 1730 made an invasion into York County driving out those who claimed allegiance to the Penn government. John Kinsey and Samuel Preston were appointed Commissioners to visit the Governor, asking that hostilities cease and that a temporary arrangement as to citizenship should be made pending a permanent settlement. Some progress was made but the Maryland commissioner got Governor Ogle away from "the seductive influences of the Pennsylvania Commission," and he left town without notice. The Pennsylvanians came home without accomplishing anything definite, but the "war" did not continue and the way was cleared for the future.

During the Speakership of John Kinsey a burning question was the issuance of Bills of Credit to be used as money. This was frowned upon by the Proprietors and by the English government, but in a new country which imported so much more than it exported, the gold and silver were drained and the pcople had to resort to barter, to their great inconvenience. To meet this difficulty the Assembly had authorized loans upon land and plate of ample security and upon this the bills had been issued. They never depreciated and this could probably be said of the paper money of no other colony. The land was rising in value and when orders came to call in the bills and Governor Thomas presented the directions to a special session of the Assembly there was universal disapproval. They refused to withdraw the bills 
already out and insisted on reissuing them when matured. To issue such bills was the popular method of raising revenue for the Province, and tho in general this was a dangerous policy, it was so carefully guarded that it worked well in Pennsylvania. John Kinsey was the great defender of the issue and was for a long time a Trustee of the Loan Office which had charge of it.

His contest in this matter and his efforts to avert war, made him popular in the province, not only among the Friends and their close supporters but also among the great mass of German voters. In a community with only a few Friends these voters would often select one as their representative and the Friends always had a three-fourths majority in the legislature. In 1741 in the midst of the controversy with Governor Thomas, a serious effort was made to divert these German voters from the Quaker alliance. Conrad Weiser the Indian interpreter, a man of great and deserved influence among them, wrote a serious address telling them how deficient the Friends were in their "rendering tribute to Caesar" and asked them to send in men who would do as the Governor wanted. The letter was widely circulated but Kinsey's hold was unshaken and the Germans stood faithfully by their old friends.

The dispute between the Governor, representing the Proprietors, and the Assembly became in time very complicated. The Governor wanted money for war with the French and Indians. The Assembly refused. He wanted any money "for the King's use" raised by taxes. They demanded Bills of Credit. He wanted the Proprietors' property excluded from all taxation. They insisted that such property should stand with others. He wanted his salary. They declined to vote it while he was unsatisfactory to them. They demanded a knowledge of lis instructions for they were tired of working in the dark. He declined to show them. 


\section{I74 POLITICAL LEADERS OF PENNSYLVANIA}

They wanted to have complete political rights even though they would not swear or fight. He insisted that such principles were subversive of government. They demanded pay to the masters for the indentured servants who had joined the militia without serving their full time. $\mathrm{He}$ balked seriously at the suggestion. Through this complex maze of difficult problems, John Kinsey steered his party wisely, unitedly and victoriously.

John Kinsey had his share in making the honorable history of the treatment of the Indians by the Friends of Pennsylvania. The days of trustfulness by the red men were over. They had seen too much of the vices and greed of the settlers to repose entire confidence in them. They had learned too that there were two tribes of white men, the French and the English who were eagerly bidding for their friendship. They were inclined to keep peace with their neighbors of the Province and good treatment would cement this inclination into an indissoluble bond. The Quaker Assembly voted willingly large appropriations for Indian presents. It meant also not to allow settlers on their lands, and to keep fire-water from them. But the Penns and the Governor wanted their land for sale to settlers and cheated and debauched the Indians to secure some infamous titles. The iniquitous "Walking Purchase" of 1737 and the enforced banishment of the Minisink Indians from their ancestral home in the "Forks of the Delaware" gave a very ugly complexion to Indian attitude. Had the Quaker Assembly had their way, the desolating wars preceding the Revolution would have almost certainly been avoided and the seventy years of peace been extended by twenty more.

It would have been better for the Indians if a white man had never set foot upon the Province. Their conversion to Christianity, which had been cherished by Penn and his friends as a solution of the race question had practically 
been abandoned. It was better to feed them than to fight them but white avarice and white disease were fast demoralizing them. They had not learned to take kindly to reservations, and were powerless against the oncoming flood of settlers. The Quaker policy would have purchised their land piecemeal in advance of occupation, and paid them enough to satisfy them, or if they refused to sell would have kept the whites off the land. But the land belonged to the Proprietors, who had none of the broad-minded philanthropy of their father, and it was necessary to patch up the holes made by their short-sighted diplomacy in the Indian relations.

Their arrangements had been almost wholly with the Algonquin tribes of the Province. But about the time of John Kinsey's prominence it became evident that the Iroquois of New York were to become a factor in affairs. They claimed the sovereignty over the Pennsylvania Indians, were sworn friends of the whites and had resisted both the force and the bribes of the French. They had saved New York from an invasion from Canada, and all the colonies looked upon them with hope as a bulwark against French aggression. They must be liberally supplied with everything the Indian heart could desire. Conrad Weiser and the Governor hoped also that they could be persuaded to take French scalps in the lake region.

The first part of the policy was acceptable to the Assembly but they would not countenance war measures. In response to a request to furnish funds the Assembly replied: "The Governor must be sensible that men of our peaceable principles cannot consistently therewith join in persuading the Indians to engage in the war. If it be thought there be any real danger of the Indians descrting the British interests and going over to the French, and that to preserve them steady in their friendship further presents are neces- 


\section{I76 POLITICAL LEADERS OF PENNSYLVANIA}

sary to secure them in their fidelity to the Crown of Great Britain and amity with the inhabitants of this and the neighboring Colonies, and the Governor can think his health and business will permit his negotiating this affair in person, we shall be willing to pay the expense to arise by it.

$$
\text { "John Kinsey, Speaker. }
$$

"Fourth month 24th, 1746."

The Governor however preferred to send a commission to Albany, with John Kinsey at its head, to join with agents of the other colonies in arranging matters with the Six Nations. The New Englanders who felt the brunt of French aggression wanted to force the Iroquois to abandon their rôle of friendly passivity for active warfare and in this they were encouraged by Conrad Weiser who had gone along as interpreter. New York was undecided and Pennsylvania actively hostile to this policy. John Kinsey argued that Pennsylvania had no interest in a war and would not sanction one unless the legislature acted favorably upon it; that such a war would open hostilities upon all the colonies; that other Indian tribes would be drawn in on one side or the other; that if the Six Nations were persuaded to go to war by white influence it would be cowardly to desert them, and it was quite uncertain what the legislatures would do. New York seems to have been won by these arguments and a divided conference did nothing, which is what John Kinsey desired. He probably averted a general war, or rather postponed it for a decade.

John Kinsey's useful life ended suddenly on May 12th, 1750 , at the age of 57 . He had gone to Burlington, his old home, to plead in court and was there seized with a stroke of apoplexy which carried him off in a few hours.

In John Smith's Journal we find this reference: "The loss of this great and good man occasions a general lamentation 
and to present appearances is irrepairable." In a private letter James Pemberton writes: "John Kinsey was a person of no small consequence to this province, being our Chief Justice, Speaker of the Assembly and in many other public posts, in all of which he acquitted himself with an unblemished character, of great skill in the law, and was of great aceount in the Society, being a person of extensive capacity and completely qualified for a serviceful man. To the irreparable loss of the province he died in Burlington in the midst of a cause he was there pleading. He acquired a great share of credit during our contest some time ago with Governor Thomas." These were the views of Friends, and in Franklin's Gazette of May 17th, we have the following:

"Friday last died suddenly in Burlington in New Jersey, the Honorable John Kinsey, Esquire, Chief Justice of the Province and Speaker of the General Assembly. His long experience and great ability in the management of public affairs, his skill in the laws and his unblemished integrity as a Judge, made his life a very valuable and useful one. His death is therefore justly lamented as a general loss."

The Pennsylvania Journal gives a more extended notice:

"On Friday last died in an apoplectic fit at Burlington in the Colony of New Jersey that truly great man John Kinsey, Esquire, of this city, the place of his birth, and was decently interred here on Sunday last. Upon the death of his father who was Speaker of the House of Representatives of that Colony, he was though young chosen a member and Speaker of the House, where he sat from his first election till the dissolution of the Assembly which happened some years after his coming to reside in this place; when the people there very much regretted that a law of the Colony disabled persons not inhabitants from representing them. But his great abilities and unshaken integrity were so conspicuous that the freemen of this county at the first election after the removal of his family hither made choice of him 


\section{I78 POLITICAL LEADERS OF PENNSYLVANIA}

as one of the representatives in the General Assembly of this province and continued him during his life. He would have been immediately chosen Speaker of our honorable house but that the chair was then filled by a gentleman of like abilities and public spirit whom they could not overlook. But that patriot in the year 1738 declining to sit longer in the house and resigning his trust of Public Commissioner in the Loan Office, Mr. Kinsey was fixed upon as the most proper person to succeed him in both stations in which he continued to the time of his decease. He was the Corypheus of law in this and adjacent provinces, sometimes Attorney General, and in April 1743 to the great joy of the people made Chief Justice of the province and has ever since sat in the Supreme Court with unrivaled reputation; and indeed would have filled with honor the first seat of Justice even in England. His death gave a universal shock to the people. We may without attempting a particular delineation of his character justly apply to him what was said of the great and good Sir Matthew Hale in last century, whose spirit he much admired. 'He was one of the greatest patterns this age has afforded whether in his private deportment as a Christian, or in his public employments as a lawyer, Senator, judge or treasurer.' So that what Horace said of his friend Quintilius will with propriety close the article concerning our late public friend: "Omnibus ille bonis flebilis occidit.'"

When John Kinsey died the days of real Quaker control of the government ended. The Legislature remained theirs for six years longer and could have so continued had they not insisted on resigning when the Governor declared war on the Indians. But they had no leader who combined the absolute confidence of the meeting with the capacity to mould public opinion and give wise judgment on public affairs. The "Quaker Party" fell largely into the hands of Benjamin Franklin who had sympathy with their demands for political freedom, but none for their non-military spirit. Their counsels became divided. The successor to John Kinsey as 
Speaker, Isaac Norris, 2nd, perhaps equally able and trusted as a statesman, was more on the fringe of meeting activities. The more strict churehmen were having an increasing distrust of the influences of public life and a rift developed between the political and ecclesiastical Quakers which made united action difficult. Whether John Kinsey had he lived would have been able to guide Friendly activities in politics in harmony with conscientious Quakerism, is a matter of speculation. But he must be regarded as the last great Quaker political leader.

There is not much to guide us in forming a judgment of the man apart from his external activities. Like the other great Quaker Chief Justice David Lloyd he left very little in the way of memoranda or letters by which to judge the man. Unlike him however he seems to have made no enemies and been open to no damaging charges. He belonged to the social circle in Philadelphia, consisting of the Logans, the Norrises, the Pembertons, the Morrises and others who combined broad intellectual sympathies, with keen business instincts and honest interest in the affairs of state, who were the best group of citizens of the city and most active in all its developments. How much he was esteemed by these is evident from many little references, but by very few direct allusions.

His home after 1735 was "Plantation," an estate of 23 acres fronting the Schuylkill on the east side near Grays Ferry, the site of the present U. S. Naval Hospital. Here he retired when his many duties permitted. About two years before his death, his son John, a youth of great promise, was killed by the accidental discharge of a gun when on a hunting trip for ducks on the Schuylkill. This greatly saddened his last years.

The minute of the monthly meeting of Philadelphia may conclude this sketch. 
"John Kinsey was born in this city about the year 1693. Being endowed with a superior natural capacity and understanding, he applied himself to the study of the law and became eminent in that profession and distinguished himself in several public stations in this and the adjacent government (New Jersey) by his integrity, candour and regard to truth and justice, being of an agreeable disposition, easy of access and free to communicate his knowledge for relief of the distressed though engaged in a multiplicity of business. He was remarkably useful and acquired a general good character, and great respect among people of all ranks. In his younger years he was signally visited by the power of truth, by which he was drawn off from the vanities and follies of the world and became serviceable in the church on various accounts. His death was sudden and much lamented, being seized by an apoplectic fit, during the sitting of a court at Burlington, and departed in a few hours. His corpse was brought to his own home in this eity, and from thence attended by a great number of people of the several denominations to our great Meeting House and after to the grave yard on the 13th of $3 \mathrm{~d}$ mo: 1750 in the 57 th year of his age, having been Chief Justice of this province the last seven years of his life." 


\section{ISAAC NORRIS, 2nd}

No one probably stood higher in general esteem and trust during the first quarter of the 18th century in the province of Pennsylvania than Isaac Norris the elder. He was the son of Thomas Norris, or Norrice, a London merchant who joined Friends very early in their history, and was born in London on July 26th, 1671. The family emigrated to Jamaica about 1678. In 1692 Isaac Norris went to Philadelphia probably on business, as there was a large trade developing between Penn's new province and the West Indies. While absent a terrible earthquake shook Port Royal to the ground and all the remaining members of the family were immediately killed or so hurt that death shortly followed. About all that was saved of the property was a large silver dish found floating in the harbor in a cradle which also contained a negro child, the daughter of a slave who had died in heroic attempts to save his master.

When he returned to the ruins of his home and had buried a brother and sister who had survived the immediate shock, he concluded to leave the strieken island for Philadelphia. In 1693 with about $£ 100$, all that was left of a flourishing business, a young man of about 21 , without near relatives or influential friends he entered into business in Penn's City.

$\mathrm{He}$ was strikingly successful. The conditions of the times afforded an excellent chance for commercial success. The triangular exchange of goods between Pennsylvania, the West Indies and England brought large gains and he was in a condition from previous experience and capacity to profit largely. James Logan calls him "a trader," which 


\section{I82 POLITICAL LEADERS OF PENNSYLVANIA}

probably meant a shrewd and successful man of affairs. James Logan also says of him, "I value his judgment far above any man's in this govermment (except Samuel Carpenter) and he is one of the most excellent of men." In a little time he was one of the wealthiest merchants of the province. William Penn, Jr. had received as a gift from his father a manor on Schuylkill containing 7000 acres. Isatac Norris and William Trent, the founder of Trenton, bought him out and Norris soon after purchased Trent's share. This included the present Norristown. He also bought several hundred acres in the Northern Liberties of Philadelphia on which he built Fair Hill, for the times a residence of considerable pretensions. Pastorius speaks admiringly of it. It is interesting also to read the description of the colonial country seat, by Deborah Logan, a granddaughter of Isaac Norris, giving as it does the life of a wealthy Quaker family.

"Fairhill built by Isaac Norris upon the same plan as Dolobran (a seat from long antiquity possessed by the Lloyd family in Montgomeryshire, North Wales), at least as to the ground floor, was finished in 1717 , and was at that time the most beautiful seat in Pennsylvania. The sashes for the windows and much of the best work were imported from England. The entrance was into a hall, paved with black and white marble, two large parlors on each side, and an excellent staircase, well lighted. The courts and gardens were in the taste of those times, with gravel walks and parterres. Many lofty trees were preserved round the house, which added greatly to its beauty, and, at the time of my remembrance, the outbuildings were covered with festoons of ivy and scarlet bignonia. Isaac Norris had been very prosperous in trade, which at that period offered uncommon facilities. His son Isaac Norris the Speaker succeeded his father in the possession of Fairhill, as he did in his talents, abilities, and public usefulness. As he was learned and fond of literature, he collected together a very good and extensive library. It was placed in a low building, consisting of several rooms, in the garden, and was a 
most delightful retreat for contemplative study; the windows curtained with ivy; the sound of 'bees industrious murmur' from a glass hive which had communication from without, and where their wonderful instinct could be viewed. Beautiful specimens of the fine arts and many curiosities were also collected there, the shelves were filled with the best authors, and materials for writing and drawing at hand. In this place Isaac Norris the Speaker spent all the time that his health would permit which was not devoted to public business." ${ }^{1}$

Isaac Norris also owned the Slate Roof House, in which William Penn resided from 1699 to 1701 . It was situated on the east side of Second Street below Chestnut. He was one of three or four Philadelphians who owned a coach. On it the coat of arms of the family was blazoned.

His standing if not his fortune was improved by his marriage with Mary the third daughter of Thomas Lloyd the Deputy-Governor and Penn's trusted friend. They had 14 children, four of whom died in infancy.

He was for many years a member of the Assembly. In politics he sided wholly with the Proprietor and James Logan, though in such a reasonable way as not to bring upon himself much of the personal opposition which the more pugnacious Logan had to bear. He was one of William Penn's most trusted and sagacious advisers, and along

${ }^{1}$ An interesting little piece of by-play is seen in the following minute of Fair Hill meeting with the good natured sareasm of Isaac Norris's comment. He had proposed an exchange of land with the meeting property and the committee reported:

"The Friends appointed to view Fair Hill lands report that they have viewed it and considered the proposal made by $1 . \mathrm{N}$. of exchanging a piece of Friends lands there, with him, for tho like quantity of his which they conceive will not he of advantage to this meeting." To which Isaae Norris added.

"Pecause if Isaac Norris keeps his land between Gernman read and the Meeting House always open as he may probably do rather than shut up the way, this merting will save their own land and get all the use of his for nothing." 


\section{I84 POLITICAL LEADERS OF PENNSYLVANIA}

with Samuel Carpenter, Caleb Pusey, Richard Hill and a few others was appealed to in all difficult matters as a wise counsellor. In 1706 he went to England and spent two years. Penn was at this time in the thick of his difficulties with the grasping family of Fords which had stripped him of many thousand pounds. His comment on Penn's business methods is interesting. "But the strange infatuation that should lead a man never to show this (Penn's account with the Fords) to any friend whatsoever before he had so olinched and closed it, is not to be paralleled nor exceeded in a man of his sense otherwise."

Isaac Norris untangled the medley, brought matters to a settlement which ultimately relieved Penn of the difficulty, and also disproved some of the adverse stories which David Lloyd was then circulating among the unfriends of the Proprietor.

He was Mayor of the city, Presiding Judge of the Court of Common Pleas and a member for about 30 years of the Governor's Council. On the death of David Lloyd in 1731 he was offered the Chief Justiceship but declined.

He was attorney for William Penn to sell lands and later for his widow, and was also one of the Trustees named by Penn in his will.

He died in 1735 in his 65 th year as the result of an apoplectic stroke in Germantown Friends Meeting.

Isaac Norris first appears on the meeting records when he asked for permission in $\mathbf{1 6 9 4}$ to marry Mary Lloyd. What happened at the wedding is not very evident but there appears to have been some "acclamations" the report of which the Keith party sent over to England as a complaint against Friends. George Whitehead, a prominent English Friend who seems on various occasions to have antagonized William Penn and his friends, asked an explanation. But the meeting cleared the parties involved of all blame. Isaac 
Norris then rapidly rose in meeting importance, his cleár head and wisely conciliatory methods finding a large place for him. Whenever a paper was to be prepared or a judgment passed on the orthodoxy of a writing or an important piece of business to be attended to, he was on the committee. Throughout his life he was a trusted and consistent Friend. Like other friends of Penn and Logan he was rather less strenuous in his anti-martial views than David Lloyd. When on the oceasion of that agitator's downfall in 1710 Isaac Norris became the practical leader of the Assembly, that body voted $£ 2000$ "to the Queen's use" without restrictions, with the argument that the way it was spent was her matter not theirs. This set the standard for the Quaker attitude in the legislature on requests for grants of money for suspicious purposes through the colonial days.

He was a man of good edueation, though how he received it does not appear. He knew enough Latin to make frequent use of it, and his letters show a good English style, far better than the hastily written composition of William Penn. He had varied interests which were reflected in the library which he collected at Fair Hill to which his son made extensive additions. After the province got through the turbulent days of infaney a fairly healthy and solid intellectual life arose in the colony of which the names mentioned in this volume are all good representatives. Neither their state nor church activities were permitted to take all their time or energy, and their early retirement from business with moderate fortunes gave them the leisure for reading and profitable intercourse. The new English books were early purchased and the standard authors in various languages earefully read. Without a college they had the advantage of a serious interest in the best literature by which they were efficiently edueated.

The son of Isaac Norris, the grandson of Thomas Lloyd, 
and the son-in-law of James Logan could not well be otherwise than an active Quaker politician. That he was always influential and after the death of Logan and Kinsey the undoubted leader of the party in the Assembly and the Province is a mild statement of his prominence. Politically no one but Franklin had any considerable share in this leadership and Franklin not being in sympathy with Friends on certain points could not carry the general respect felt for Isaac Norris, 2nd - "The Speaker," - as he is usually designated to distinguish him from his father.

He was born in 1701 the sixth in the family. The home of his early life was the "Slate Roof House," and as the oldest son at the time of his father's death he inherited Fair Hill. Here late in life he brought Sarah, the daughter of James Logan, to be his wife.

His first public office was in 1727 when 26 years old he became a member of the City Council. Three years later he was made magistrate and in 1734 a few months before his father's death, he became a member of the Assembly of the Province. The division between parties had now shifted from the days of Darid Lloyd. William Penn and his wife were both dead and his sons were becoming unsympathetic in their attitude to Friends. Besides, the immigration of non-Quakers was creating a condition that forbade disunion in their ranks. So while the elder Isaac Norris was a strong adherent of the Proprietors the son immediately cast in his lot with the liberty party, whose opposition to the Proprietors and their Episcopalian adherents was beginning to develop. The lines however in these early days were not hardly drawn and for a few years under the leadership of the Speaker Andrew Hamilton there was a good degree of harmony. When John Kinsey succeeded Hamilton in 1739 and the question of peace and war was added to the differences about secret instructions, the taxation of the Penn 
lands, the issue of paper money and other economic questions, the contest becime more virulent.

Isaac Norris, 2nd had gained his large place in public estimation partly by his fanily connections and character, and partly by his mereantile experience, which made him an authority on all matters of trade. After his first election he wals made chairman of a committee to make a report on the resources of Pennsylvania to be sent to England. This was a valuable and comprehensive statement and attracted attention to the young Assemblyman.

When John Kinsey was made Speaker in 1739 Norris became his chief assistant and as we have seen in the sketch of the former, the great controversy between the Deputy Governor and the House on the question of appropriations for war and the right of peace loving men to have their consciences respected became acute. Feelings were embittered and polities ran riot. In 1741 the "Norris party" as the Friendly connection was often called was defeated in the city, and the Friends after this never regained the control of the city government. It was a different matter however to deieat Norris in Philadelphia (now Montgomery) County, yet it was very important to do so if the Governor was to control the situation. In "the bloody election of 1742 " a serious riot occurred, the facts concerning which were about as follows:

The opponent of Norris was the wealthy William Allen then Recorder of the city and as such responsible in part for the conduct of the election. The Germin voters in gratitude for the liberal treatment they had received, and their freedom from military service and heary taxes were invineibly friendly to the Quaker candidates and the opposition claimed that unnaturalized Germans had been voted. On the morning of election day some 70 sailors in the interest of Allen armed with clubs gathered around the polls and 
when the Recorder was appealed to to keep the peace his reply was "They have as good a right to be there as the unnaturalized Dutchmen." Very little effort was made to prevent a riot and the riot came. Men were knocked down around the polling place and the sailors for a time held possession. Reputable citizens like Israel Pemberton were rudely treated, and a reaction of public feeling probably aided the Norris party. When the roughs were driven away and the election was allowed to proceed, Norris was chosen by a considerable majority. The Assembly took ample testimony and without avail urged the city authorities to punish the rioters.

The Assembly at this time was opposing the Governor, who as agent for the Penns was endeavoring to acquire by fair means or otherwise the right to settle all parts of the province. It had been bought of the Indians piecemeal and the rapid immigration of the peaceful years from 1710 to 1740 had effected the sale of much of the lands already purchased. Hence it was desired to secure more from the Indians, for the Assembly insisted, so far as lay in their power, that purchase must precede settlement. The trick of the "Walking Purchase" by which a sort of title was had for lands lying between the Delaware and Lehigh Rivers had alienated the Pennsylvania Indians, and the Iroquois of New York who claimed a kind of sovereignty over them were called in to move them out of the way to the banks of the Susquehanna.

In a noted Council held in Philadelphia in 1742, the chiefs of the Five Nations professed to make a judicial examination of the title deeds and to decide the question of rights. They had always been friendly with the English as against the French, but now having established their claims to recompense, word came to Philadelphia that they had also been treating with the French in Canada, and that their 
future allegiance nust be secured by presents and new treat. ies. It was also hoped that they could be induced to take up arms against the French. A general conference was therefore called to be held at Albany in 1745 to be attended by delegates from New England, New York and Pennsylvania, and Thomas Lawrence of the Governor's Council, John Kinsey the Speaker and Isaac Norris were the Pennsylvania delegates. Norris kept a journal of bis trip to Albany, now in print. ${ }^{1}$ The results of the conference have already been given. Kinsey and Norris were in close accord. Their Quaker ideas kept them from removing their hats in the presence of the Governor of New York, which he demanded, and they therefore remained outside several of the conferences doing their work, probably none the less effectively, in private meetings with the Indian chicfs. They gave liberal presents at parting and Brother Onas again stood well with the Indians. The Iroquois were persuaded not to take up the batchet on either side and war was averted.

In 1751 Norris succeeded John Kinsey as Speaker of the Assembly, a post which he held till nearly his death. It was a result of his 30 years' service in this legislative body that his fame as a statesman must rest. It is safe to say that during this time no important measure went through without having strongly felt his inipress. During the early years he was most intimately associated with Kinsey and during his late years with Franklin, but always his strong individuality stood out. No one but must respect his stern integrity, his capable management and his high ideals of independence in public service. His frequent election was compromised by no self seeking schemes, but his attitude simply was, that his time and abilities were at the service of the state, if they were needed and desired. The roters responded, placing him usually at the head of the poll.

${ }^{1}$ Pennsylvania Magazine, Vol. 27, 1. 20. 


\section{I90 POLITICAL LEADERS OF PENNSYLVANIA}

Up to 1729 the Assembly had met in a hired private house or occasionally in the Friends Meeting House. In that year an act was passed authorizing a commission of which the Speaker of the Assembly was chairman to construct a house and two thousand pounds was appropriated for the purpose. Differences arose as to the location and plans and nothing was done till 1732. Finally the State House, the fine chaste central building we now see, was adopted and construction was started. To Andrew Hamilton belongs the credit as architect and overseer of the erection. But he had to bear much criticism, and had spent some of his own money and on Jan. 18th, 1734 he asked to be discharged from further responsibility.

This does not seem to have been granted and two years later he secured the two lots, one on the corner of 5 th and Chestnut and the other at the corner of 6 th and Chestnut, which he transferred respectively to the city and county of Philadelphia for courts and other public uses. Upon these lots at a later date the two corner buildings fronting on Chestnut Street were placed.

In 1738 Andrew Hamilton rendered his final account showing the expenditures upon the State House proper and the land on which it stood to be $£ 4446$.

In 1751 when Norris became Speaker he thought it necessary to crown the structure with a bell. In ordering from England his instructions were, "Let the bell be cast by the best workmen and examined carefully before it is shipped with the following words well-shaped in large letters round it; viz.: 'By order of the Assembly of the Province of Pennsylvania, for the State House in the city of Philadelphia, 1752,' and underneath 'Proclaim Liberty throughout the land, unto all the inhabitants thereof. Levit. XXV: 10.'" The bell imported was cracked in the trial ringing and recast in Philadelphia. Isaac Norris said, "they have made 
a good bell which pleases me much that we should first renture upon and succeed in the greatest bell for aught I know in English America - surpassing too the imported one which is too high and brittle - the weight was 2080 lbs."

When Isaac Norris directed the inscription he could hardly have foreseen its prophetic character, but it was rung immediately after the reading of the Declaration of Independence in 1776 and the "Liberty Bell" is the most cherished relic of American history.

Isaac Norris was appointed to another Albany treaty with the Indians in 1754. The commission consisted of John Penn and Richard Peters representing the Proprietors, and Benjamin Franklin and himself the Assembly. Indian relations were becoming difficult. The Five Nations still elaimed the right to the ownership of Pennsylvania and insisted that no sale of land by the Delawares was permissible. In an evil hour the government of Pennsylvania recognized this claim and this Albany meeting was for the purpose of effecting a purchase. By methods which were more or less unfair, taking advantage of the Indian ignorance of geography, they bought for $£ 400$ all of southwestern Pennsylvania. When the Delawares found that their land had been sold without iheir consent, they threw off the Iroquois yoke, joined the French, defeated Braddock's army a year later and for the first time in the history of the Colony the horrors of Indian warfare were known on the frontiers. What part Isaac Norris had in framing this treaty may not be known. Primarily it was the work of the agents of the Proprietors who wished to sell their lands. His own attitude had always been so fair and friendly to the Indians that it is hard to believe that he was artively interested in the proceedings. But there are indications that his relations with Friends were less close in his later years. 


\section{I92 POLITICAL LEADERS OF PENNSYLVANIA}

It was on this expedition that Franklin presented to his fellow delegates his plan for a union of the Colonies, of course in subordination to the English Crown which was a precursor of the final union in Revolutionary days. Sixty years earlier William Penn had proposed a somewhat similar scheme.

The war eame, French intrigue and the unwisdom of the Executive branch of the government of the Province drove the Indians, who for seventy-three years had been friendly, into the warpath. Cries came in from the frontiers of homesteads burnt, men shot at their plows, women and children sealped or carried into horrible captivity and a growing sentiment among the red men that the French were the stronger and that the English were to be driven into the sea.

For the past ten years while this state of affairs had been preparing the Quaker Assembly under Norris's leadership had adopted a definite course. The wisdom of appropriations had been complicated by the efforts of the Penns to avoid their fair share of taxes on their unsold lands, and by their attempt to diminish the powers of the Assembly in the matter of appropriating and expending publie money. But in the matter of military defense the Assembly had practically said, "We will not violate our conseiences, or ask our constituents to do so by laws enforcing military service. We will not require citizens who are not conscientious to perform the service for us. But we reeognize that we are the servants of the provinee and not of a seet, and when men voluntarily form companies for defence we will supply the needed money." So they voted taxes "for the king's use" whenever the defense of their rights permitted with a not illiberal hand. They equipped and fed voluntary militia. They built a chain of forts to fence off the Indian territory. They voted supplies to Braddock's 
army. In this poliey they were supported by the Province and year after year were elected by large majorities.

In the spring of 1756 the Governor and Council declared war against the Delaware and Shawnese Indians. The Assembly was asked to appropriate money. This brought matters to a crisis. The more conservative Friends had been inclined for some time to question the consistency of war taxes with their professions of peace and in 1755 a number refused to pay them, suffering distraint of goods. A Quaker Assembly imposing taxes against which the Quaker conscience revolted was an unedifying spectacle. Matters were brought to a head by a bill introduced into the British Parliament to require an oath of allegiance of all members of colonial legislatures. This was especially aimed at the Philadelphia Friends, and would have driven them all out of office. To avert this result certain English Friends agreed to advise the retirement, at least temporary, of enough members of the meeting to give the non-members a majority and sent over two delegates to urge this view upon the colonists. Prior to their arrival six members led by James Pemberton had resigned. A number of others declined reëlection in the fall of 1756 and the meeting authorities did their best to induce such as had been elected also to withdraw.

In the fall of 1755 just after the Braddock defeat while the war was still raging on the frontiers the Province had elected out of an Assembly of 36 members, 26 Friends. As a result of the self-effacing efforts but twelve members were left after the election of 1756. These however contained two distinguished leaders. Creorge Ashbridge had been sent up by Chester County continuously since 1743. When the committee of his Monthly Meeting tried to show the impropriety of his retaining his post, the only report they could make of his attitude was "He do not feel himself 


\section{POLITICAL LEADERS OF PENNSYLVANIA}

culpable." He held his place till his death in 1773, the undoubted choice of his constituents for thirty years.

The other was Isaac Norris. He also declined to resign. The two delegates from England had personal interviews with all Friends in the Assembly. "They first waited on the Speaker Isaac Norris and if they could have prevailed with him to decline it would have the desired effect on the others now remaining but they had no effect further than that he approved of what the others did. ${ }^{1}$ "He had been in the Assembly for twenty-two years and was to remain eight more. It is quite probable that though he was in the main a loyal Friend, he did not seriously disapprove of the measures taken to defend the Province from the French and Indians and he knew the value of his leadership. He probably saw the need of the break-up of the Quaker majority and now that was secured preferred to continue his useful services as Speaker. James Pemberton writes in another letter in 1765 "It is with some reluctance several of us enter again into this service the disposition of our Speaker whose conduct you can not in all respects approve renders the task the more disagreeable."

The influence of Norris is strikingly shown in a pamphlet printed in 1758, the author unknown, called The Chronicle of Nathan ben Saddi, in which the leaders of the popular party are satirized. William Moore was Judge of the Common Pleas of Chester County and a violent partisan of the Proprictors. He expressed great dislike of the Quakers and openly abused them in a way to cause great irritation. A number of charges were preferred against him by his constituents, charges of serious misconduct and injustice. The Assembly asked him to appear and answer them. He denied their authority to summon him and in violent language refused to appear. Provost Smith of the University had

${ }^{1}$ Private letter of James Pemberton. 
Judge Moore's reply printed in German and widely distributed. For this they were arrested in January 1756 for libel. It was in the midst of the excitement of this controversy that the satire appeared. The prominent actors are mentioned by false names but easily distinguished at the time. We are concerned now only with the part referring to Isaac Norris.

"And Isaac the judge did according to the sayings of Adonis the Scribe (Franklin) and he mouldeth the Councillors in his hands even as a potter mouldeth the clay.

"So they gave him a great report among the people, and he grew proud in heart saying to himself,

"I bid one go and he goeth, and another run and he runneth. Am not I great in authority? If any man stand against my sayings thus and thus shall it be done unto him.'

"And he became haughty and his mind swelled within him and he went from the ways of David his father.

"And he made an image of paper in the shape of a calf, and the body scemed as though thirty ealves were joined together but there was only one head and the head was like unto the head of Isaac the judge."

The thirty calves probably refers to thirty members of the Assembly who followed his lead.

The Friendly majority in the Assembly never returned. The Yearly Meeting persistently advised its members to accept no public places the duties of which were likely to compromise their principles and a succession of Indian and French wars seemed to make membership in the Assembly one of these questionable offices. Each year we have reports as to the number of Quakers. They never, except possibly once, amounted to a majority though it is evident that they would have been had the will of the people governed the selection. It was however the same party acting through different representatives, and Isaae Norris was its undisputed leader. Among the Friends there was no com- 
petition and Benjamin Franklin was the only man outside the Society who was greatly influential in its councils.

A correspondent of Thomas Penn after detailing the efforts of his friends to procure the election of "sensible and reasonable" men to the legislature of $\mathbf{1 7 5 6}$ had to admit that their efforts were vain, and that the "veriest partisans against the Proprietors" had been returned including "one Quakerized Presbyterian and two Quakerized churchmen" heading the list with Isaac Norris. He said that "the Quakers were never more active though a few serious and grave men did not show themselves." The "Quaker party" ruled the state till the Revolution.

War questions having been placed somewhat in the background the contest with the Proprietors became the issue between the parties. The Friends led by Norris and Franklin and aided by the Germans and some of the Scotch-Irish Presbyterians of the west were vigorous opponents, while many of the wealthy Episcopalians of Philadelphia rallied around the governor and the Penn family. The popularly elected legislature was always overwhelmingly for liberty from the restrictions imposed from England, and by limiting supplies and the salary of the Governor forced one access of privilege after another from the unwilling hands of the sons of William Penn. But these owners of a large part of the Province were too strongly entrenched in their inherited rights and privileges to be seriously affected by anything within the power of the freemen of the Province even though party feeling ran high and one legislature after another sent up its petitions and demands.

The war must be carried into England and in 1757 Franklin and Norris were appointed agents to present the popular claims to the English government and to strive after some satisfactory arrangement with the Proprietors. Norris de- 
elined on account of ill-health and Franklin went alone, accomplishing however but little.

The feeling became more and more bitter and by 1764 the great body of the liberty party including the most of the Friends were of the mind that one remedy alone was left, the dispossession of the Proprietors of any share in the government and the acceptance of a Governor appointed by the Crown. This popular demand was reflected in the Assembly and in May, 1764, a resolution to that effect was passed by a large majority. The Speaker opposed it, and John Dickinson who was afterwards his son-in-law made his first great speech on the same side. But it was of no avail. Isaac Norris was now a feeble man and though treated with great respect could not control the House. He now informed them "that for 30 years past he had had the honor of serving as a representative of the people of the Province, and for more than half that time as Speaker; that in these offices he had uniformly endeavored to the best of his judgment to promote the public good. That the subject of the present debate was a matter of the utmost importance to the Province. That as his sentiments on the occasion were very different from the majority, and his seat in the chair prevented him from entering into the debate, he therefore prayed the House that if in consequence of their order his duty should oblige him to sign the petition as Speaker he might be permitted to offer his sentiments on the subject before he signed, and that they might be entered on the minutes."

Out of courtesy the request was granted but the next day he was not able to attend and instead sent in his resignation as Speaker. A most flattering testimonial to the value of his past services was sent by the House asking for a withdrawal of the resignation, which he declined, and Benjamin Franklin was chosen in his place. 


\section{POLITICAL LEADERS OF PENNSYLVANIA}

Franklin was however defeated for reëlection in October 1764 and Norris against his wishes was elected, and was again voted into the Speakership. This insistence upon his holding the place by a House which did not agree with his position on the important issue of the day is an indication of the strong respect and confidence of the Province. Franklin was again sent to England to effect the transfer, but the encroachments of the Crown soon caused the people of Pennsylvania to change their mind and accept the judgment of Norris. Franlilin presented the petition but did not press it, and it was never granted.

After a few days, Isaac Norris resigned again, and after an attempt to elect George Ashbridge, Joseph Fox succeeded to the chair.

He died at Fair Hill on July 13th, 1766.

In his political life he was the type of dignified honesty and devotion to the public service. A friend says of him: "In all his long public career he never asked a vote to get into the House nor solicited any member for posts of private advantage or employments." Happy the state which can call into its service and retain for a lifetime such a man, without asking him to vary his honest judgment or sacrifice aught of his independence. As he said on one occasion when he left the Speaker's chair to speak on a matter of much moment, "No man shall ever stamp his foot on my grave and say, "Curse him! Here lies one who basely betrayed the liberties of his country.'

Isaac Norris was not especially prominent in Friendly affairs. Except as Clerk of the Monthly Meeting he does not seem to have held church positions. But his prominence, integrity, abilities, social position and wealth gave him a large standing among them as well as others and he always emphasized his connection. He regularly attended the Friends Meeting adjoining the grounds of Fair Hill, 
on a lot which William Penn had given George Fox for the use of Friends. Deborah Logan says that after the Firstday Meeting "All the decent strangers who frequented it were sure of an invitation to dine with him, where, as in the time of his parents, a good table and the warmest welcome awaited them." His influence among others was probably the greater that he did not always do as the strict Friends desired and no one questioned his general loyalty and the sincerity of his convictions.

His married life was short, his wife Sarah Logan Norris dying in 1744. Two sons died in infancy and the daughter Sarah in 1769, shortly after her father. Mary, the oldest, married John Dickinson. His unmarried sister, Elizabeth, became the kindly genius of the household which was a happy and harmonious one. He spent much of his leisure time in his library building which he had erected separately from the house and hence was saved from destruction when the British burnt the residence of the "arch-rebel Dickinson." He was Trustee of the College, afterwards University of Pennsylvania, and was active in every movement for the development of the intellectual life and welfare of the city. He wrote French and Latin fluently and read most of the books of consequence of cotemporary literature.

Thus as a man who was both scholarly and practical, adaptable and conscientious, tolerant and religious, he was able to guide the youthful Province through rather stormy times when the Holy Experiment had to be tempered with many conflicting interests and divergent judgments. 


\section{JAMES PEMBERTON}

When state and church duties seemed to conflict, Isaac Norris usually decided in favor of the state. Under similar circumstances James Pemberton would give his preference to the church. Both were men of high principles and strong character. Both had the political instinct strongly developed, and found it difficult to keep out of public life. Both were men of means, good education and social standing, closely related to each other by marriage. But Isaac Norris, 2nd, had an ancestry and education which tended towards what was practical and possible, and would bend his desires to secure it. James Pemberton lived more in the atmosphere of unwavering principle as was the habit of the stricter Friends of earlier days. The type of thought of Isaac Norris, 1st, and James Logan, was not quite the type which characterized the ancestors of James Pemberton.

The Pemberton family came to Pennsylvania in the fall of 1682 about the same time as William Penn. The group consisted of Ralph Pemberton, 72 years old, who soon died, his son Phineas, aged 33, James Harrison and wife, whose daughter Phebe had married Phineas Pemberton, and a number of children, relatives and dependents. An uncle had preceded them to the Province and had bought land in Bucks County nearly opposite the site of the present Trenton and this determined them to seek homes in the same neighborhood. James Harrison was placed in eharge of William Penn's country place, Pennsbury, and Phineas Pemberton bought 300 acres near by, and later a larger 
track farther from the river. Almost immediately he was seized upon for public service, first as register for Bucks County, then in 1685 as a member of the Assembly for Bucks County, with increasing trust and confidence as the years went by. The eivil afiairs of his county came largely into his hands and in 1696 he succeeded Thomas Lloyd as Master of the Rolls of the Province. He died in 1702, aged 53 years and as Samuel Carpenter writes to William Penn, "He will be greatly missed having left few or none in these parts or the adjacent like him for wisdom and integrity and a general service." He was equally prominent in the church, serving as clerk of the Yearly Meeting and otherwise.

Phineas and Phebe Pemberton had nine children of whom four outlived him. We are eoncerned with Israel the eldest surviving son. He eame to Philadelphia as a boy and served his apprenticeship to Samuel Carpenter, the great eapitalist of the day, and soon established himself in very large successful mercantile transaetions. He became the wealthiest and best known merchant of Philadelphia. In 1710 he married Rachel Read, whose sister was the wife of James Logan.

By his financial and social position thus assured, his inherent abilities and trustworthiness and his generous hospitality unrivalled in the Province, he rapidly gained confidence and respect and held a series of important places in church and state. For 19 suceessive years from 1731 to 1750 he was a member of the Assembly, and in 1745 was elected Speaker, but declined. Like his father he was elerk of the Yearly Meeting and after 1729 an elder.

His political life covered the high water mark of Quaker domination, and while not obtrusive, its effectiveness was attested by the numerous committees for routine service of which he was a member. It was a model of fidelity and usefulness. 
He left his large estate to his three sons, Israel, James and John, the only ones of his ten children who survived him.

The atmosphere of the Pemberton home was devoutly religious. To build up their spiritual life by consecration, kindness and service was a constant effort. The voluminous letters of the three brothers are some of the best treatises on the conditions of the times, giving us the inner history of Quakerism as a religion and as a factor in government. Mostly addressed to English correspondents like Dr. Fothergill, and the travelling ministers who went through the colonies and when in Philadelphia made the Pemberton houses their homes, they give the sort of information which is often taken for granted in correspondence between friends of the same community. John was a minister. There is no trace of any but religious interests in his letters. He travelled extensively in Gospel service and died at Pyrmont, Germany, while thus engaged. But Israel and James were very wide awake to every feature of provincial life. They took part in politics, joined societies for conducting hospitals, for slavery abolition, for Indian coneiliation, for every beneficent movement of the times, while their purses were liberally opened for private charities.

Israel Pemberton "the head of the Quaker interests" as John Adams called him in pre-Revolutionary times or "the king of the Quakers" as he was dubbed by the people in general, was the oldest and in some respects the most influential of the three. In later life he lost his interest in ordinary provincial politics when the Quaker policy of Indian conciliation was exchanged for warfare and refused for ten years even to vote.

A little piece of by-play may give some light on the small political troubles of his early days. In the exciting contest of 1739 when he was about 24 years old he criticized the 
Governor most severely in a conpany of which Alexander Graydon (he whose memoirs we read with so much interest) was a member. He said that it was the Governor's design to overturn the Constitution, and reduce them to the King's government; that the Governor carried on the debate without dignity; that he had no doubt that the Governor would use his influence in England to set the Assembly in the wrong, and that he would make an unjust representation of the matter. Graydon narrated this conversation to the Governor, and the next day told Pemberton so, upon which Pemberton said he was glad of it; that he would not make any apology, for it was a good thing that these truths should come to the Governor's knowledge, for his sycophants who lived around him would never tell him, and that he would prove that the Governor said that he would bring matters to extremities. This would not now seem a very serious offense, but the Governor was rash and issued a warrant for the arrest of Pemberton. After some discussion in the council as to the legality of this warrant, it was allowed to proceed. The Supreme Court interfered, however, with the serving of the warrant, issued a writ of habeas corpus, and ordered that Israel Pemberton, Jr., should not be called before the council, which simply indicates that the court and council were on different sides of the political controversy. The Governor declared this writ illegal, and again ordered the sheriff to serve the warrant, who reported "that Pemberton read the warrant and called it nonsense; that he, the sheriff, being ordered by the secretary to behave toward Mr. Pemberton with civility, had permitted him to go out of his sight in the house of John Kinsey, Esq., after his word was given that he would not escape, and he notwithstanding, had escaped." The Governor would not excuse the sheriff, and Pemberton was held in legal confinement, the Governor having come to the conclusion that the writ of 
the Supreme Court was illegal, under the circumstances. He therefore instructed the sheriff again to find Pemberton, but he had gone to Chester. However, he came back the next day. The sheriff then reports in these words the trouble which Israel gave him in the attempt to serve the warrant:

"That yesterday about twelve of the Clock he came to town; his Deputy gave him a Warrant from the Governor to take Mr. Pemberton, Junr.; that he went to Mr. Pemberton's House about one of the clock, and had answer that he was not in town; he went again about three of the clock, and had answer that he was gone out; he went this morning about three-quarters of an hour after Eight in the morning, and asked his Clerk or Book Keeper if Mr. Pemberton was at home, who said he was, and went to some other Apartment of the House, as he thought, to see for his master, but returned and said his Master was in bed; Mr. Robinson went to another Door of the House, and asked Mrs. Pemberton if Mr. Pemberton was within, who said he was in Bed; Mr. Robinson asked what time he would be up, and had answer he would in half an hour; he went towards Mr. Pemberton's House about twelve of the Clock, and in his going down Chestnut Street, by John Miller's at the Sign of the City of Dublin, he saw Mr. Pemberton standing on the Platform at his own Door, but when he had got so far as Front Street, he saw Mr. Pemberton tack about and go into his House, and since has seen nothing of him."

Evidently the Governor was making himself ridiculous, and the Quaker was getting the better of the manoeuvres. An intermediary was found in Andrew Hamilton, the Speaker of the Assembly, who said that Israel Pemberton, Sr., was very uneasy " at his son's being compelled to keep his house for fear of being taken by the sheriff, to the great prejudice of his business," and the warrant was withdrawn.

Israel Pemberton with his great capacity and wide interests could not well keep out of public life. For a short 
time he was in the Assembly and took an active part on its important committees. After the Indian War of 1755 broke out he gave the most of his time and much money to striving for a reconciliation. "The Friendly Association for gaining and preserving peace with the Indians by pacific measures," was formed, Israel Pemberton being the leading figure.

The Walking Purchase of 1737 and the subsequent forcible removal of the Minisink Indians from their ancestral homes between the Delaware and Leligh Rivers, the Albany Treaty of 1754 when the Indian rights in all western Pennsylvania were sold to the Penns by the Iroquois without regard to the dwellers on the soil, French intrigue and the invasion of traders and settlers had transformed the Delaware and Shawnese Indians, the ancient friends of William Penn, into bitter and inveterate foes of the frontier white men and sent them into warfare. The Friends addressed the Governor offering to pay " a much larger portion of our estates than the heaviest taxes of a war would be expected to require " for the purpose of regaining the friendship. The Association hoped first to detach the chief Tedyuscung and the northern Delawares from the French alliance. A large sum of money was raised, chiefly by Friends, partly by sympathetic German sects, to purciase presents. Conferences were held at Easton in 1756, at Lancaster in 1757 and again at Easton in 1758. Israel Pemberton earried $£ 2000$ to Pittsburg the following year to treat with the western Indians. The Friends had the satisfaction of knowing that their diplomacy, their presents and their influence had pacified the Indians and for a little time peace prevailed on the frontier.

The Indians appreciated the differences among the whites and saved the frontier Quakers from the tomahawk and burning buildings. Israel I'mberton said after the 
1758 treaty, "It was by justice the first settlers of the province obtained their (the Indians) friendship and the name of a Quaker of the same spirit as William Penn still is in the highest estimation among their old men . . . and there is a considerable number of us here united in a resolution to endeaver by a like conduct to fix the same good impression of all of us in the minds of the rising generation."

But they did not have as elear a field as William Penn had. The Lieutenant-Governor, the agent of his master in England, Thomas Pemn, had commercial designs on Indian land which the first Proprietor would have spurned. His party in Pennsylvania excited by Indian outrages on the frontiers and by the hope to get Quakers out of the government pressed him for vigorous measures. The contest kept up for years with alternate success. The spirit of the Friendly Association, in its endeavor to smooth the way on both sides is conveyed in an address to the Governor from a meeting held in Israel Pemberton's house late in the year 1756 where they say:

"If our furnishing them a supply of clothing against the approaching winter in addition to what is provided at the public expense may . . . be consistent with the Governor's pleasure we shall cheerfully provide them . . . to be delivered by the Governor in such measure as will most effectually promote the public service and express our friendly disposition toward them."

It was to this eause that Israel Pemberton devoted his energies up to the Revolutionary War. By friends and foes alike he was regarded the leader of the movement. "King Wampum" beeame another of his pseurlonyms. Hard he had a free field it is not improbable that he might have solved the problem of harmonizing red men's rights with white men's reasonable desires. He did restrain several tribes from the warpath and so saved the lives of many 
frontiersmen. But while his friends carried the legislative branch, the executive was out of their reach and the Indian question was ultimately settled by the military arm driving the nitives from the Province, the Friends tempering the process as they could.

The embitterment of the frontiersmen, especially the settlers from the north of Ireland, towards the Quakers was strikingly shown in 1764 when a band of them after exterminating the Conestoga tribe in Lancaster County, marched down to Philadelphia with the ostensible purpose of giving a band of Moravian Indians the same ruthless treatment. If the Quakers made any show of resistance, they, and especially Israel Pemberton, were to be treated in like manner. A demand was made that he be given up to the rioters. Israel seems to have considered prudence to be wise under the cireumstanees and having been adrised that his life was in dinger "was banished for a few days."

All the Friends, however, did not run away in this manner. Some 200 of the younger among them opened the Meeting House at Market and Second Street, stacked their arms in the gallery and in company with many other eitizens awaited the attack. The "Paxton Boys" never got further than Germantown where they were met by a committee of which Benjamin Franklin was the head, persuaded to state their claims, some of which were just, and finding that they hat no chance against a city in arms, went back to their homes.

Then followed a pamphlet warfare in which the relative rlaims of Preshyterianism and Quakerism were discussed with great arerbity. Benjamin Franklin came to the front against the lynchers and was gratefully received by the Friends as an ally. "The Quaker Unmasked" wats at severe arraignment of their policy, which was replied to by 
"The Delineated Presbyterian Played Hob With." The first stated that "to govern is absolutely repugnant to the avowed principles of Quakerism" and the second, "to be governed is absolutely repugnant to the avowed principles of Presbyterianism " - both of which statements have in them an element of truth. There were many stronger and indecent charges made and Israel Pemberton was the target of a large share of them without, however, so far as we know, provoking any reply from him. He weathered the storm, however, in the esteem of his friends and had the satisfaction of seeing the Indian question settled in Pennsylvania for colonial times with as much justice to the red men as could reasonably have been expected in the excited condition of the frontiersmen. The only concession which the "Boys" obtained at the time was a temporary offer of rewards for the scalps of male and female Indians, a strange edict to come from the grandson of William Penn.

When the question of handing over the government to the king came up in 1764 and the general feeling against the proprietors became so strong in the Province as to turn most of the Quaker sentiment away from them, Israel Pemberton took the conservative position along with Norris and Dickinson. In a private letter he seriously eritieized the unwise policy of Thomas Penn and his selfish actions towards the colonists and Indians, but he judged, and as it turned out, judged rightly, that the chances of a Crown eolony were no better. He sympathized strongly with the Speaker in his efforts to defeat the transfer. A paragraph in a letter of his probably explains as fully as anything the action of that official in the last days of his public life.

"We expected the advice and conduct of Isaac Norris, who had for many years been Speaker of our Assembly, would have had some effect but in this we were disan- 
pointed. Last summer being in a weak state of body, and tired out with the tedious controversies with the Governor, when he found the Assembly in general determined in pursuing those measures, which he apprehended it unsafe to be accessory to, he chose to resign his seat. Some change being this year made in the Assembly, and his state of health much recovered, as it was said the Governor had instructions to make some concessions, he entertained the hopes of promoting a reconciliation, and restraining from precipitate measures. He then was induced to consent to accept the Speaker's seat again, but when he found the Governor declined communicating anything towards a reconciliation, and that the majority of the present Assembly were bent on pursuing the measures he had before disapproved, after giving the house his sentiments thereon, he ag:in resigned his seat and retired home heartily concerned for the unhappy circumstances of his country, which he could neither redress nor prevent, his salutary advice being rejected with contempt by those who formerly revered it."

The reaction from any tendency towarls royal government came almost immediately. England began the series of taxation experiments which a decade later brought on the Revolutionary War. The opposition was general. Refusal to pay taxes, agreements for non-importation and nonexportation, the ejection of officers who were deputed to collect the Stamp taxes, were, with the possible exception of the last, quite Quaker methods of resistance. The names of over fifty Friends are on the agreement to import no more English goods, and the list includes Israel Pemberton. They, however, while resisting, counseled moderation and it is largely due to this that the measures were milder than in Boston. Thus when the tea ship came in 1773 consigned to a Quaker firm, instead of the spectacular performance of Boston Harbor, they sent it back without unloading the cargo, loaning the captain enough to victual. If some of their statements seem unnecessarily loyal in tone, it must be remembered that nearly a year after this George Washing- 
ton had declared, "No such thing as independence is desired by any thinking man in America," and John Adams had pledged even Massachusetts to the statement, "That there are any who pant after independence is the greatest slander on the Province." But sentiment developed rapidly after this.

There seems to be little doubt that Israel Pemberton and the other wealthy Quaker merchants of Philadelphia were British sympathizers during the war. That many, perhaps most, of the membership were not so is probable. The Meetings disowned every one who took any part, however slight, in resistance in either direction and the minutes show some 400 who in this way brought upon themselves the penalty on the American side and perhaps not more than a half dozen on the British. The testimony against both was borne impartially. But those who remained in good standing adopted, whatever their sympathies, the policy of non-partieipation beeause of conscientious opposition to the means used. It is at least probable that the Friends who actively joined the Ameriean forces were not without the conseiousness of a large body who agreed with their objects if not their methods. The long struggle for liberty against Proprietary and Crown encroachment did not leave them without a fellow feeling for the cause even when they could not actively join. But we can hardly include in this list the Pembertons and their elosest associates.

Perhaps the best authority on the Quaker position during the war, because unbiased, is Brissot de Warville, a French traveler who went through the country in 1788 , afterwards guillotined in Paris as a Girondist.

"It was at this epoch (the Revolution) particularly that an animosity was excited against them (the Quakers) which is not yet entirely allayed. Faithful to their reli- 
gious principles, they declared they could take no part in the war, and disavowed or excommunicated every member of their Society who served with either the American or the British army.... Notwithstanding my principles, I do not the less think that the violent persecution of the Quakers for their pacific neutrality was essentially wrong.

"If their refusal had been the first of this kind; if it had been dictated solely by their attachment to the British cause; if it had only served them to conceal the secret proofs which they might have given of this attachment, certainly they had been culpable and perhaps persecution had been lawful. But this neutrality was enjoined upon them by the religious opinions which they profess, and which they have practised from their origin. But exclusive of this, whatever prejudiced or ill informed writers may have asserted, the truth, which $I$ have taken great pains to obtain, is that the majority of the Quakers did not incline more to one party than to the other; and that they did good indifferently to both, and in fact to all those who stood in need of assistance. If some of the Society of Quakers served in the British Army, there were some likewise who served in the American army - and amongst others may be mentioned the names of Generals Greene, Mifflin and Lacy; but the Society excommunicated indifferently all those who took up arms. ...

"I have heard no one speak more impartially of the Quakers than this celebrated man (Washington) whose spirit of justice is particularly remarkable. He acknowledged to me that in the course of the war he had entertained an unfavourable opinion of the Society; he, in fact, knew little of them, because at that period there were few members of the sect in Virginia. He attributed to their political sentiments what was the effect of their religious principles. When he encamped in Chester County, principally inhabited by Quakers, he supposed himself to be in the enemy's country, as he could not induce a single Quaker to act for him in the character of a spy. But no one served as a spy against him in the employ of the British army.

"General Washington, having since better understood the spirit of the Society, concludes by esteeming them. He acknowledged to me that, on considering the simplicity of 


\section{I2 POLITICAL LEADERS OF PENNSYLVANIA}

their manners, their fondness for economy, the excellence of their morals, and the good example they afforded, joined to the attachment they showed for the Constitution, he regarded them as the best citizens of the new government, which required a great degree of obedience and the banishment of luxury." 1

John Adams in his Diary tells us of an unexpected encounter with Israel Pemberton when in 1774 the New England delegation came to Philadelphia to enlighten the Quakers and others as to the principles of liberty as developed in Massachusetts. They were invited to a meeting in Carpenters Hall and they concluded that their opportunity had come. But the Friends took charge of the meeting. Israel told them very plainly that "Friends had a concern about the condition of things in Massachusetts; that they had received complaints from some Anabaptists and some Friends against certain laws of that Province restrictive of liberty of conscience.

"The laws of New England and particularly of Massachusetts were inconsistent with liberty of conscience for they not only compelled men to pay for the building of churches and the support of ministers but to go to some known religious assembly on First-days; and that he and his friends were desirous of engaging us to assure them that our state would repeal all those laws and place things as they were in Pennsylvania." This turning of the tables was a sad blow to the complacency of the delegates of the "Sons of Liberty." They denied the enforcement of such laws of recent years but stated that " they might as well hope to turn the heavenly bodies out of their annual

1 "Noureau Vovage dans les Etats-Unis de l'Amerique Septentrionale fait en 1788; par J. P. Brissot (Warville), Citoyen Francais." The portion here translated is omitted in the English edition of 1792. See ILazard's Register of Pennsylvania, Vol. VIII, page 315 . 
and diurnal course as the people of Massachusetts at the present day from their Meeting House and Sunday laws." They then began to explain how such laws were compatible with liberty of conscience but Pemberton called out, "Don't urge liberty of conscience in favor of such laws." Unquestionably the Quaker had the better of the debate for the facts were on his side and Israel Pemberton was too aggressive a pacifist to lose the opportunity.

When in the fall of 1777 the British Army was approaching Philadelphia the American government undertook to remove leading eitizens who were suspected of sympathy with the invading foree. This will be treated more fully later in this chapter. The three brothers Pemberton were arrested and by a rather arbitrary stretch of athority were banished for eight months to Winchester, Virginia. They were then released with something of an apology. But the severe winter which froze up the American Army at Valley Forge was too much for the Philadelphians suddenly removed from the comforts of the eity to the bleak quarters of west Virginia. Two of them died during the winter and Israel Pemberton was so weakened that early in 1779 he died aged 64 years. He was the only one of the brothers who left any descendants of the name. One of these by a strange reversion was ihe Southern General Pemberton who surrendered Vicksburg to General Grant in 1863.

James Pemberton writes of his brother: "His health was much impaired by a fit of sickness at the time of our exile and was never perfectly restored. The various afflictions with which he was of late years encompassed had much contributed to weaken his constitution and vital strength which the death of his wife six months before his own further affected; but by exerting himself he kept about most of the winter and was active on many necessary occasions 


\section{POLITICAL LEADERS OF PENNSYLVANIA}

for the relief of the afflicted and oppressed with whom he always nearly sympathized and was unwearied in his endeavors to promote their ease and redress, on which account and his superior abilities, assiduity and resolution in difficult cases relating both to religion and civil society he is and will be much missed among us, his integrity, benevolence and many other virtuous qualifications rendered him generally respected and his death greatly lamented."

James Pemberton the second of the brothers was born in 1723. He had all the opportunities which Philadelphia afforded for an education, with a year in England. His brother Israel was a man of courage and initiative full of aggressive plans which absorbed his energies but who seldom allowed himself to be tied down to official life. James was the useful man, the politician, the office holder, the letter writer, using the words in no belittling sense, who while aiding his brother's large interests carried on the details and committee work most efficiently and successfully.

In church affairs he was a member of the "Meeting for Sufferings," the executive body of Philadelphia Friends, from its origin in 1756 till 1808 a few months before his death. He was for about thirty years including the Revolutionary War the Clerk of the Yearly Meeting, the practical President of that court of last appeal of the Quaker system. He was on important committees whenever needed and for a half century or more very little went on without his co-operation in the affairs of his church.

He was a member of the legislative Assembly of the province in 1755 and 1756 and again after 1765 . His letters ${ }^{1}$ are a mine of wealth concerning political and eccle-

1 For many facts in this paper the author is indehted to these manuscript letters not previously examined for purposes of publication. 
siastical matters in the provinces from his view point. He was an intimate associate and, except in matters of warfare, a strong believer in Benjamin Franklin. He founded the Pennsylvania Abolition Society, persuaded Franklin to accept the presidency and on his death in 1790 succeeded him in the place. He was the confidential friend of Dr. Fothergill and David Barclay who with Dr. Franklin attempted the not unlikely experiment of a reconciliation of England with the provinces just before the war and used Pemberton as their colonial agent. Their letters agree closely with Franklin's account in his Autobiography.

The Assembly of the Province was made up largely of farmers, the best to be had. They were honest, intelligent, and well-intentioned, but lacked for the most part a knowledge of political history and business training. The opportunities of a country Friend for anything but an elementary education were very limited, mostly non-existent. In a clear case of provincial policy their judgment could be relied on to do the right thing. Penn had drilled into them the possession of certain rights as to legislation which they tenaciously held to. How they came to be selected as candidates is an interesting but unknown subject. Probably as there was but little emolument and no graft connected with the office there was no great competition, but by some process of nomination the Quaker machine maintained its supremacy and sent from the three populous counties a practically unanimous line of these sectaries up to 1756 . Even from the frontier counties mostly made up of non-Quakers from Germany it often happened that a Friend was selected to represent their views on peace or taxation.

In such an Assembly men like David Lloyd, John Kinsey, Isaac Norris and James Pemberton with thcir legal and business training, their large contact with the world, 


\section{POLITICAL LEADERS OF PENNSYLVANIA}

their sturdy character and their sympathetic appreciation of the point of view of their simple and trustful associates would have unlimited influence and create the unity of action in plans and policy, so strikingly displayed in the legislative history of the province. The City of Philadelphia had two members and each of the counties surrounding it eight. Towards the end of the provincial period new counties were taken in, and an apportionment, probably unfair, gave them a smaller representation. The city members were largely depended on to supply the leadership and while the Quaker population there found it more difficult than in the country to carry its representation, they often succeeded when a strong man like James Pemberton could be found to lead them. We find him therefore frequently elected and serving on the most important posts.

The constitution gave them rather unusual privileges for a colonial legislature. The right to meet without call from any power, to adjourn at will, to be free from arrest, to control money affairs, to have their laws recognized unless vetoed by the crown and the other rights as claimed by the advanced freemen of the day, were guaranteed to them in Penn's Frame of 1701 and they were always looking very seriously at anything that seemed an infringement. But when it came to putting this sensitive feeling into action they had to depend on the creative wisdom and literary ability of the city members. It was probably no great disadvantage that they had to fight at the polls for their rights during these years. It kept the sentiment for liberty awake and in action. The details were somewhat unlike those in New England, but each was approaching the same goal by a different method, the Puritan by a process which was sure to culminate in avowed resistance, the Quaker by legal methods, by appeal and argument, by a refusal to obey oppressive laws, and a willingness to take the conse- 
quences of disobedience. Had they been able to control the province at the outbreak of the Revolutionary War a test of the efficacy of their policy might have been made, but the action of 1756 put them out of power, as they probably did not appreeiate, forever.

In the spring of 1755 the Quarterly Meeting of Philadelphia largely under Pemberton influence sent to London a paper explaining the circumstances of Quaker ascendeney in the legislature. They told how the Friends had been elected without exertion on their part often against their wishes, and that this applied to counties where they were in a minority as well as others; that for sixteen years they had been kept in power by voters who did not share their pacific principles; that their policy had advanced the interest of the proprietors by the general prosperity of the province; and that if there were others who could be relied upon to preserve the liberties guaranteed by the charter and maintained by them they would be quite willing to be relieved of the thankless task of engaging in the controversies of the times. It was the last defense of active Quaker participation in politics and in the main unanswerable.

But when in the crisis of 1756 the London Friends advised abstention to save the general imposition of an oath, James Pemberton and six other Friends gave up their places in the Assembly. This was the beginning of the break. The meetings acting on the advice used their efforts to have others withdraw and four more yielded and resigned. In the fall a number refused reëlection. James Pemberton probably held the key to the situation and his action determined the loss of direct Quaker control for the future.

But the habits and instincts developed by seventy years of political control died slowly. For the next ten years there might at any time have been a Quaker Assembly, if the meetings had not exerted themselves to prevent it. In 


\section{POLITICAL LEADERS OF PENNSYLVANIA}

1761 after the war ended there was probably a majority of nominal Friends, but steadily the "weighty" Friends opposed. James Pemberton whose political tendencies were hard to keep down, made a sort of an apology for accepting reëlection in 1765 . He agreed "with reluctance" "through solicitation of Friends" "to keep out an envious Pres_- n." (It will be remembered that this was in the hot days of the Presbyterian-Quaker controversy following the Paxton riots of the year before.) "Valuable interests were suffering because no one properly represented them," and so on. The troubles which led up to the Revolutionary War seem to have convinced most Friends that they had better confine their attention to local and moral affairs.

In the controversy over the transfer of the government to the King he inclined to take the popular side for he was much opposed to the demands of the Proprietors. At least he says while not expecting much from the Crown, he thinks that the agitation will bring the Proprietors to terms. His idea of the attitude of a Quaker politician in a contest is expressed by the statement, "Christian charity teaches us to forgive our enemies and Christian prudence to beware of them." He supported the idea of sending Franklin to England and writes Dr. Fothergill: "No man in the province has been so influential in promoting the public good; the most useful institutions we have among us may be attributed in great measure to his great understanding and disinterested regard for the welfare of the province."

Among the institutions referred to the Pennsylvania Hospital is prominent. It was a Quaker concern from the start. In 1709 the Monthly Meeting of Philadelphia made a move in this direction by sending over to England by James Logan a request for financial aid and a charter for a hospital. What reception this met with is unknown, except that nothing resulted. 
In 1751 Dr. Thomas Bond and Benjamin Franklin took up the matter again. In a little time popular subscription and an appropriation from the legisliture gawe the necessary financial basis, and thus started the first hospital for sick and insane in the new world. The largest contributors were Friends and so were a mijority of the managers for 150 years. Israel Pemberton, Jr., served on the bo:trd from 1751 until his death in 1779 and James Pemberton from 1756 to 1780 when he resigned "for various considcrations." Such work was strictly in line with the Pemberton idea of charity, to all branches of which they were liberal contributors of time and money. The hospital served as a sort of headquarters for Quaker leadership in the days following 1750 as did the college, now university, for the Episcopalians.

About the same time James Pemberton sent in an earnest protest against New England Friends "removing to settle on the lands in Nova Scotia from whence the poor unlappy neutrals were in the beginning of the war removed, as such a settlement does not appear suitable for any under our profession when we consider the manner these distressed people were dispossessed." As at this time he was interested in all the city charities it is not a large streteh of imagination for Longfellow to nute the ministrations of Evangeline in the Friends' Alms House where "her ear was pleased with the Thee and Thou of the Quakers."

It is not a matter of wonder that the authorities in the troublous days of September, 1777, should have been looking for British sympathizers in Philadelphia. Sir William Howe was marching his army toward the eity from the Chesapeake. This corner of Pennsylvania had never been warm for the war. There were outspoken militant Torics besides the non-militant Friends, and spying was evidently going on extensively. How far Friends were actively implicated they did not know. 
To ascertain this the minutes of the various Meetings were seized. Those of us who since that time have had the opportunity to read these volumes, know that there was nothing stronger than appeals to the members to be faithful to their principles. So the officials found; and the books were soon returned. Then they decided to banish a group of the more suspicious people, striking more particularly those whose prominence would produce popular effect. About forty were selected of whom nearly half were Friends. They were not tried or heard, though they sent urgent appeals and statements of their position to the Council of the State, to Congress, and to the people of Pennsylvania. Chief Justice McKean allowed a writ of Habeas Corpus which was ignored. Their private papers were examined and nothing incriminating was found. Then they were offered freedom on taking oath or affirmation of fidelity to the new government, which seemed too much like a confession of guilt for most of them to agree to. Other tests were applied and the list was reduced to twenty, of whom seventeen were Friends. The decree was that they were to be banished to Staunton (changed to Winchester), Virginia, at their own expense. This banishment lasted until spring, when General Washington intervened on their behalf, and the orders came to conduct them back to Philadelphia through the lines of both armies "treating them on the road with that polite attention and care which is due to men who act on the purest motives, to gentlemen whose stations in life entitle them to respect however they may differ in political sentiments from those in whose power they are."

A sort of a joint journal was kept, written by James Pemberton which has been printed. Two of the exiles succumbed to the severe treatment and died in Virginia and others were greatly weakened. Almost immediately on their 
return they joined with other Friends in another appeal to the members for fidelity to the anti-war attitude of the past.

When the war was over the energies of James Pemberton were directed largely to two causes in addition to the general work of the Society. If he desired further political life, which is doubtful, it probably would not have been accorded him for a decade, for by meeting action and popular wish it was denied to Friends.

$\mathrm{He}$ was interested in educational movements among Friends. Evidently the cause was at a low ebb, and all the more so because many of the better educated Philadelphia Friends had actively espoused the American side in the war and been disowned. The country Friends, worthy, moral, traditional people, had nothing but their elementary schools attached to the meeting houses to give them training. There are probably few opportunities for education better than the conjunction of an aspiring youth with an inspiring teacher in an ungraded school, and such opportunities sometimes present themselves. But neither side of the condition was fulfilled in most cases and a rather materialistic attitude relieved somewhat by the idealism of some of the preaching in meeting was settling down on the Society. The objection to theoiogical training as unnecessary was extended to mean objection to higher education as undesirable, and mediocrity was spreading its dangerous hold. James Pemberton was a friend and active correspondent of John Dickinson, Owen Biddle and others who had a larger vision and a better background and in course of time Westtown Boarding School evolved from the controversy, opening its doors in 1799 . The school itself was for some time largely elementary but it gave to certain Friendly youths a chance to come in contact with a better type of scholarship than they had been used to and was the beginning of better days. 


\section{POLI'TICAL LEADERS OF PENNSYLVANIA}

The other interest for which James Pemberton wrought most assiduously was less denominational - the cause of anti-slavery. The Friends had cleared themselves during the war of holding slaves and had at least partially paid the freed negroes for past services. Pennsylvania in 1780, the first among the states, passed a law for gradual abolition. Past efforts had reluced the number of slaves in the state to about 4,000 , while in the surrounding states there were 103,000 in Maryland, 9,000 in Delaware, 11,000 in New Jersey and 21,000 in New York and the people were ready almost unanimously for a forward move in the nation at large. The Yearly Meeting in 1783 sent to the Congress of the Confederation a paper asking it to take steps towards abolishing the slave trade signed by 535 Friends, but that body was too powerless to do anything. As soon as the national government was formed they again made an attempt. They called attention to the former paper which had been followed by action in a number of states, and appealed to the Golden Rule as the basis of action. An acrimonious debate followed. A year later a petition from Warner Mifflin, a Friend from Delaware, who had freed and taken care of his own slaves was "returned to him by the clerk of the House" after serious controversy. Again in 1797 a Quaker memorial produced a violent debate.

These petitions while creating no immediate legislation did bring about a large growth of popular sentiment. During all the years up to the Civil War Friendly action stimulated and to a large extent led the anti-slavery movement.

These early congressional debates brought out the standing of Friends as to their war attitude. The Southerners attacked them as undesirable citizens on account of their record. "We took each other with our mutual bad habits and respective evils for better, for worse; the northern states adopted us with our slaves and we adopted them 
with their Quakers," said Smith of South Carolina. On the other hand the northern Congressmen especially those from Pennsylvania and New Jersey were their eulogists. Boudinot, the Commissary-General during the war testified that their voluntary relief of suffering had greatly aided the situation.

James Pemberton during these times was President of the Pennsylvania Society for Promoting the Abolition of Slavery which he had founded and of which he was the mainstay, and to this cause he gave much of the energy of his declining years. He died in 1809, eighty-five years old, greatly respected. 


\section{JOHN DICKINSON}

THE men whose lives we have been considering divided their interest in state and church in varying proportions. Thomas Lloyd was primarily a minister and reluctantly assumed the burdens which his pre-eminent fitness placed upon him as political leader of the colony. David Lloyd was an ingrained politician looked upon at least in his earlier days with considerable distrust by the Friends of weight in the meeting, but ever faithful to the traditions and testimonies of the Society. James Logan and his sonin-law Isaac Norris tried to put Quaker principles into active operation but found the difficulties so great in the case of those relating to warfare, that they somewhat compromised. John Kinsey held his own in both fields with remarkable success and was trusted as a shrewd and clearsighted political leader, no less than as the man of influence and power in his Yearly Meeting. James Pemberton equally faithful in both never had the preëminence of Kinsey in either, but was always a most useful and intelligent citizen and churchman.

John Dickinson was very little of a Friend in his early life. Though descended on both sides from Quaker ancestors, finding his wife in a Quaker household, and leaving children imbued with Quaker loyalty and ideals, it is not certain that he was ever a member, and as we shall see later, it was not till old age that his sympathies were given to the Quaker connection.

He was descended from a Quaker family who emigrated to Virginia in 1654 and a few years later moved to the 
Eastern shore of Maryland at a plantation which they called Crosia-doré. Here John Dickinson was born on November 8th, 1732. His father was Samuel Dickinson a lawyer, and afterward Judge of the Court of Kent County, Delaware. His mother was Mary Cadwalader, sister of the noted Dr. Thomas Cadwalader of Philadelphia. Judge Dickinson meant to give his son the best education the colonies afforded. But the three colleges then in existence, Harvard, William and Mary, and Yale, were too eeelesiastical in scope and spirit to attract a Quaker. John was confided to the care of a young Irishman, William Killen, afterward Chief Justice of Delaware. From this nationality not a few of the teachers of the Middle States in colonial times were drawn. It proved a happy ehoice and the bright boy, through his training in the classics, secured an English style, simple, direet, and eloquent, upon which was based much of the effectiveness of his later writings.

When he was 18 years old he was sent to Philadelphia and entered the office of the leading attorney of the town, John Moland. After three years of study here he induced his father to send him to London to enter as a student of law at the Inns of Court. Here he had the best training possible for an English speaking youthful lawyer. He developed the legal and historical inteiests so conspicuously useful in his politieal eareer, and which gave the bias to his mind, which later contrasted so strongly with the New England patriots with whom he was to work in the establishment of the nation. While they appealed to the rights of man he sought his sanction in history and constitutional principle. While they became excited and revolutionary he approached the questions ealmly and reasonably, and after a certain point conservatively.

In 1757 we find him again in Philadelphia starting the practice of law. As a lawyer he achieved an early suceess 


\section{POLITICAL LEADERS OF PENNSYLVANIA}

though as a biographer says "He possessed considerable fluency, with a sweetness of tone and an agreeable modulation of voice. . . His law knowledge was respectable though not remarkably extensive for his attention was directed to historical and political studies."

His public life began in 1760 at the age of 28 when he was elected to the Delaware legislature. The two provinces had both been the property of William Penn, and while their legislatures separated in 1701 the Penn Family appointed the governor in both, sometimes the same person. Their public men were somewhat interchangeable, and John Dickinson after the war at different times held the Governorship of both states.

Two years later he was elected to the Pennsylvania Assembly from the City of Philadelphia. This was just when the question of the advisability of appealing to the crown to substitute royal for proprietary government was becoming acute. Franklin was urging it and Joseph Galloway, a legal competitor of Dickinson's, was making effective speeches for the movement. The most of the country Friends somewhat exasperated by the proprietary pretensions had been swerving to the same side. The older city Friends of weight and influence led by the Speaker Isaac Norris held back, partly from attachment to the old William Penn Charter of 1701 under which they were still working, partly because they feared the unknown possibilities of royal rule. Franklin and Dickinson the mature man of the world and the youthful student of history and law were the chief opponents in this contest as they were in many others to follow.

The policy of the Penns was certainly indefensible. The refusal to pay their share of the taxes on their immense estates, their binding their deputies by secret instructions, which would be revealed after the Assembly had wrestled 
for weeks with a subject and had drawn up a bill only to find that it had all the while been impossible to have it passed, the frequent attempts to drive the Friends from the legislature by the enforcement of an oath of office, the selfish methods of dealing with the Indians which had provoked war, the opposition to paper money issues which had largely but conservatively stimulated trade, had created a settled and reasonable hostility to their rule, and had produced a mass of adverse but ineffective legislation. The Penns, seeure in England as they deemed themselves to be in their now enormous returns from quit-rents and the sale of land, thought they could afford to defy opposition. But one resource seemed left to the colonists, to force the power from their hands and trust to the chances of better times under a governor appointed by the erown.

Dickinson was therefore on the unpopular side as was frequently the ease in his future political life. While admitting the grievances under proprietary rule he mistrusted the British ministry, and the course of events, beginning almost immediately after this, justified his sagacity.

At present however the province was in the throes of an Indian War provoked primarily by the injustice of the whites, but immediately by the conspiracy of Pontiac. The Delawares and Shawnese, the friendz of Onas for 70 years, the "women" of the Iroquois, were now the fiercest of border ruffians. The Assembly, now non-Quaker, voted supplies liberally for defense. The Penns yielding something to the necessities of the case still insisted on unreasonably low taxation for their land, and their Governor vetoed a bill of supplies, preferring that the frontiersmen should suffer rather than submit to an equitable demand. The Assembly more humane yielded the point and the feeling against the Proprietors did not diminish by the ineident.

Galloway expressed the general demand in a series of 


\section{POLITICAL LEADERS OF PENNSYLVANIA}

resolutions when in 1764 the Assembly met. They were in response to a number of petitions signed by country Friends, their chief opponents the Presbyterians of the frontiers, and by the Germans. On the other side were the Episcopalians, Presbyterians and Friends of Philadelphia who advised holding to the old Charter.

The resolutions were passed all but unanimously, apparently in Dickinson's absence, but on May 26th he made a famous speech, which while it did not change the vote in the Assembly had a powerful effect on popular opinion. The speeches of Galloway and Dickinson were printed and are both masterly statements of their positions. Both were based on real arguments and studied logic, fortified by historical examples and constitutional principles. ${ }^{1}$

"Benjamin Franklin and John Dickinson greatly distinguished themselves, the first as a politician the other as an orator" says Simuel Foulke a colleague.

Dickinson however carried with him neither the house nor his constituents for he was defeated for election for the five following years. Franklin again went to England to urge the decisions of the Assembly, but the series of attempts at British taxation beginning about the same time he was advised by his friends not to hurry the issue, and the dawn of the harassing legislation which led up to the Revolu-

1 The dehate produred most angry feelings between the two main contestants and Dickinson challenged Galloway to a duel, which was declined. "That a Quaker should challenge a Quaker may well cause surprise," says a biographer. As a matter of fact probably neither was a Quaker, though both were members of Quaker families. In the histories of the times the term Quaker was used rather freely to include all who belonged to the "Quaker Party" or who took affirmations instead of oaths, or whose families were of this persuasion.

Dickinson was greatly inflamed and says in his reply, "Presumptious indeed must 1 appear should I venture into these lists, against a person who wields the weapons of wordy war - the only weapons he dares to wield." 
tionary War soon took away all wishes for a royal government. In 1770 Dickinson triumphantly came back into the Assembly.

In the meantime he entered upon a series of studies and writings which extended his fame far beyond the boundaries of his province. The Indian wars were over for the time, the French had been driven from the continent, and now England began to levy taxes to pay the bills incurred for the benefit of the Americans. John Dickinson brought his constitutional knowledge and effective style into the defense of the colonies against taxation imposed from England. A paper against the Stamp Act was widely read and made him a delegate to the impotent Congress of the Colonies of October, 1764, called to announce the conditions on which they were willing to be taxed.

But two years later came the first of the "Farmer's Letters" which gave their author the first place in America as leader of the opposition to Britain's pretensions. From this time till 1776 this young man in his thirties was proclaimed as the rising hope of the defenders of American rights.

The Farmer's Letters, fourteen in number, following each other in rapid succession, read by all classes, solidificd and made consistent and logical the gathering feeling against the mother country. They seemed to prove the justice and reasonableness of the position and propounded a theory on which all could unite. For though many fell away when it came to independence, there were but few who did not now have a lurking feeling that they were being imposed upon. The letters crystallized and made respectable this feeling by a political philosophy which satisfied the educated and the ignorant alike. They referred to English law to prove that constitutional resistance was sanctioned and so made easy the conversion of the conservative lovers of 
the old country, and they contained the appeal to colonial patriotism which warmed the hearts of many who were just beginning to think that more than constitutional resistance might soon be possible. For the present however they disarmed the movement for more serious measures by showing that legal remedies might produce the result desired.

Boston in a town meeting voted "that the thanks of the town be given to the ingenious author of a course of letters published at Philadelphia, and in this place, signed 'A Farmer' wherein the rights of American subjects are clearly stated and fully vindicated." Princeton gave him an honorary LL.D. All social organizations of Philadelphia opened their doors to him. Translated into French they were widely read and praised, and did something to develop the sentiment of that fermenting nation. John Dickinson was the great man of America. Nothing could be done without his leadership. He carried his conservative friends with him in non-importation and non-exportation agreements and in numcrous remonstrances and commercial attacks upon British interests.

True to his feeling that force was not now the proper remedy against oppression he mildly disapproved of the destruction of the tea in the Boston Harbor and thereby incurred the reprobation of Samuel Adams and the more revolutionary Bostonians. His settlement of the question was better expressed by the Philadelphia method which sent the tea ship back to England without unloading, advancing money to the captain to revictual her.

It was however decmed of great importance to have Dickinson vigorously espouse the Boston side of the controversy and Paul Revere was sent to Philadelphia in $\mathbf{1 7 7 4}$ to insure the coöperation of that city. Dickinson would however go no farther than to express his sympathy with Boston and to counsel conciliation. The gentlemen through 
whom Revere acted, Thomas Mifflin, Charles Thompson and Joseph Reed, one a Friend, another closely associated with them, knew that for any united and effective Philadelphia support which would include Friends, Dickinson must be secured. They tried every means to win him without further success. Thompson says "The Quakers courted and seemed to depend upon him." Indeed he appears to have had the unlimited confidence of all parties and it was admitted that no movement could succeed except with his concurrence.

Then came the days of the Continental Congress. Dickinson was a member from Pennsylvania and up to the date of the Declaration of Independence wrote the most of its state papers. It was these papers that drew from Lord Chatham the eulogy "I must declare and avow that in the master states of the world I know not the people or the Senate who in such a complication of difficult circumstances can stand in preference to the delegates of America assembled in General Congress in Philadelphia."

These papers were the last hopeless efforts to avert war and revolution, which Dickinson hated, and the fact that he succeeded in getting them through the Congress in the face of the more determined representatives of New England and the South, shows the strength of his influence. John Adams called him " a piddling genius," which, however doubtful may be the meaning, was not intended to be complimentary. On the other hand his old opponent Galloway fast developing into a positive loyalist opposed him bitterly.

He was holding a middle ground and as is usually the case retained it with difficulty. A leader in demanding redress, yet compromising by nature, he stood out against radical measures on the one side and submission on the other. 
In this he probably fairly represented his Quaker connection. The Friends had been vigorously opposed to any infringements on popular rights whether by Proprietors or Crown. Up to 1755 this had been done through their own membership, afterwards through representatives chosen by them. They had gained one point after another by legal means. In England where they had no political power, when laws went against them they protested and suffered. The method had been effective and Quaker scruples were often crystallized into legislation.

They yiclded exact obedience to all edicts, and had a testimony against plots and revolutions, but they were inflexible in disobedience to laws which touched their consciences. They granted freedom of conscience to all others and demanded it for themselves. Now they were approaching a time when their love of liberty and their hatred of revolution and war were to conflict. Could they gain their points by appeal to the king, to the English people, to constitutional rights, all would be well and in this movement John Dickinson was their hope.

His papers had made him influential and distinguished above any man in America and it did not seem impossible that he could carry the country. He was appealing for undoubted rights and privileges, needing not the support of illegal or revolutionary proceedings, rights which had the same foundation as trial by jury. The true English mode of resistance was by petition and remonstrance which generally proved effective in time. There were of course possibilities of unreason or obstinacy on either side in which case resistance by force must follow, but he warned the ministry that if this came to pass the responsibility would be with them. On the other hand he tried to moderate the extreme measures which the New England delegates were preaching, urged on by the popular fceling at home. A 
normal vigorous agitation, an appeal to English justice and English constitutional methods of resistance rather than premature and violent action was the content of his preaching, but neither Old nor New England was in a condition to respond. Franklin in England was writing that the tea sunk in Boston harbor should be paid for and seemed to be his ally.

But appeals failed and the radicals forced independence, revolution and war, and here for a time ended the popularity and influence of John Dickinson. He was too much of a patriot to join Galloway and the loyalists; too cautious to sign a measure which he considered premature and which would lead to consequences which might be fatal; too little of a Friend to oppose war for its own sake. His argument was that without foreign aid a rebellion would not be successful and foreign aid should first be secured. In the first point he was probably right, and in the second the colonists took their chances. The French came in to save the situation.

His speech on this occasion was an eloquent plea for moderation. John Adams had invoked the "God of Eloquence." Dickinson replied, "The gentleman who spoke last began by invoking a heathen God. I shall introduce what I have to say by humbly invoking the God of heaven and earth to inspire me with the knowledge and love of truth and if what I am about to say in opposition to the Declaration of Independence should be injurious in any degree to my country I pray God to overrule my arguments and to direct us to such a decision upon this weighty question as shall be most for the interest and happiness of the people committed to our care. . . . I know too that I have acquired a character and some popularity with them, both of which I shall risk by opposing this favorite measure. But I had rather risk both than speak or vote contrary to the dictates of my judgment and conscience." 


\section{POLITICAL LEADERS OF PENNSYLVANIA}

Though defeated in his method he did not sulk but joined the Revolutionary Army first as an officer, then, when driven out of his place by political enemies as a common soldier. He had lost his standing with the people and after his career in the field retired to private life on his Delaware plantation.

A few years later he could not resist the call to Congress from Delaware and, after a brief service there, to the Governorship. By the end of the war there came a conservative reaction and Pennsylvania turned to Dickinson. In 1782 he was elected a member and soon after the President of the Supreme Executive Council, practically the Governor of the state. He held this place for three years and was succeeded by Dr. Franklin. ${ }^{1}$

In 1787 when the Convention which framed the Constitution of the United States met in Philadelphia John Dickinson was a member from Delaware. He had himself drafted the Articles of Confederation under which the states worked since 1776, but no one saw more clearly than he, their inadequacy to meet the conditions of a permanent union. His intimate knowledge of the history of the free institutions of England and other states made his services

1 A glimpse, not very flattering, is given of Dirkinson in 1783 by a German travoller Johann Davisl Schoeff. He says, "I desired to make him my duty, and in order to be receivel by him I had recourse to a physieian of my arquaintance, who excused himself on the ground that he had been against the Governor at the last plection." Then he tried an Ameriran Mayor who also made some trivial exense. Then "I betook myself" to a Quaker confidently believing I had eome to the right man since Dickinson himself is of the Society of Friends; but my Quaker assured me he had nothing to do with the Governor." Another doctor also declinel. "I regretted I eould not meet with one whose vainglory not satisfied with the government of so considerable a province as Pennsylvania was at the same time putting in for another that of the state of Delaware. But this may have been from lofty patriotism." 
of great value. He was the author of the scheme by which the upper house of the federal legislature was to be composed of two from each state thus recognizing the rights of the smaller states. As delegate from Delaware he felt it to be a part of his duty to sce that the doctrine of the rights of states as enunciated in the constitution should not permit the overwhelming influence of the more populous ones.

When the form of the Constitution was finally agreed upon he was urgent for its adoption by the people and wrote over the signature of Fabius a series of articles in explanation and support of it. Delaware and Pennsylvania were the two states first to adopt it.

In the old age of John Dickinson his political sympathies took an unexpected turn. The well known caution and conservatism of his younger years might have been expected to deepen with age. Instead he allied himself with the Republican Party of Jefferson with whom he carried on a most sympathetic correspondence. He greatly rejoiced in the early days of the French Revolution, though deprecating the eruelties and atheism into which it developed. He was often consulted and wrote many letters of advice as to publie matters of consequence. Several suggestions were made to him to accept a United States Senatorship from Delaware and other offices, but nothing could tempt him from the life of quiet unofficial interest in publie affairs. On February, 1808, he died in his 77th year and was buried in the graveyard attached to Friends Meeting House in Wilmington, Delaware.

Such is a brief epitome of his publie life. However we may differ as to the wisdom of his positions, we ean readily recognize the eonsistent patriotism, the intelligent and studious advocacy of important movements, the lack of asperity in his judgment of opponents, the intellectual grace and culture of the man, and his permanent influence upon the nation he helped to ereate. 


\section{POLITICAL LEADERS OF PENNSYLVANIA}

But what of John Dickinson the Quaker? Prior to his marriage at the age of 38 there is little in his life, except perhaps a certain quietness of manner and conciliatory spirit, to suggest his membership with Friends. The probabilities are that he was not a member, though why there are not facts known to show. Apparently his parents were Friends and he would have a birthright membership. Possibly one of these lost the right before he was born in which case his name would not be recorded on the books. He did not use the Friendly " thou" and "thee" or the numerical names of the months even in writing to his family. His education was away from Friends and his associates after he came to live in Philadelphia were many of them of other denominations.

He would however often find a congenial household at Fair Hill. The Norris family would have large intellectual as well as political attractions for the young student. Isaac Norris and he were closely associated in their opposition to the change of masters from the Proprietors to the Crown. The ample library would be a source of profit and pleasure and the entrance was easy for him with his graceful manners, ample means and fine intelligence to whatever was best in the society of the colonial capital.

Isaac Norris died in 1769 and his daughter Sarah a few weeks later. Only Mary Norris was left of the family. She became the wife of John Dickinson in 1770 and as the heirs of Fair Hill they lived there "in great elegance." John Adams speaks of Dickinson's calling on him "in his carriage and four beautiful horses," and that "his residence was very fine with its beautiful prospect of the city, the river, the country, fine gardens and a very grand library."

Mary Norris was an interested Friend but could not marry a non-member by Friendly methods. It was then a serious matter to marry "out of the Society" and the result usually was "disownment." 
The account which follows therefore indicates that her husband was not a Friend. "Thou will be greatly surprised," her uncle William Logan writes " to hear that our niece Polly Norris was married last night to John Dickinson. . . She was married at the Widow Norris's by George Bryan (a Magistrate). . . . I am greatly concerned for the example Polly has set by this her outgoing in marriage. I fear she has slipped from the top of the hill of reputation she had gained in the Society and among her friends, and that it will be a long time before she gains it again if ever. I wish she may not repent it."

But Polly probably never repented it. She retained her memnership, and largely through her her husband and ehildren were influenced in the same direction.

Had John Dickinson been a Friend in early life his membership would not have survived his military experience during the war. Some writers have said that he was too important a man for the Quakers to lose, but such little knew the prompt, unbending, impartial action which followed every departure however slight from the straight line of peace, on either side of the controversy.

At the end of the war however there are many evidences of his elose approach to Friends, though he never joined in membership. His letters used the Friendly language no matter whom he addressed. He became a regular attender of Friends Meeting and interested himself in their affairs. $\mathrm{He}$ joined with them in the abolition movement, freed all his own slaves and drew up an emancipation bill for Delaware, which however was not adopted. He wrote to his cousin James Pemberton letters of concern that the Friends of the day read no literature but Quaker literature, and tried to encourage a wider literary interest. He wrote to them eloquently against the idea which was probably rather widely spread among them that education was in itself dan- 


\section{POLITICAL ILADERS OF PENNSYLVANIA}

gerous. "So assured am I that learning and religion will be found to agree together that I think it the indispensable duty of those who revere religion to cultivate learning in order to counteract the mischiefs flowing from its perversions and apply it to its proper use."

To further encourage the idea he urged the Friends to establish a school and made to it liberal contributions in money and real estate. This came to an issue in 1799 and Westtown Boarding School still in honored existence was the fruit of their joint efforts.

He and his wife give to Wilmington Monthly Meeting of Friends a sum for the education of children of those not in affluent circumstances. Other benevolent projects were committed to other organizations of Friends.

His identification with Friends was so close that he was usually considered a member. Thus we have this testimony from the son of Chief Justice Read:-

"I have a vivid impression of the man, tall and spare, his hair white as snow, his face uniting with the severe simplicity of his sect a neatness and elegance peculiarly in keeping with it; his manners a beautiful emanation of the great Christian principle of love, with that gentleness and affectionateness which, whatever may be the cause, the Friends, or at least individuals among then, exhibit more than others, combining the politeness of a man of the world familiar with society in its most polished forms with conventional canons of behavior. Truly he lives in my memory as the realization of my beau-ideal of a gentleman."

But during all these years he was not a member with Friends. This was a matter of doubt till the recent discovery of two letters, one in the Historical Society of Pennsylvania, and one in the Friends Library in Devonshire House in London, seems to set the matter at rest.

A correspondent writing without date but probably about 1787 is urging him to join Friends. She says: "Thou 
mayst be a suitable laborer in the work if disposed to. It is a worthy act not only to do good ourselves but to induce others thereto. If thou wast become a member of Society thou mightest with just assistance of others also yoked in mind to the service become as Dr. Fothergill, a vigilant advancer of it into execution. But that must depend on thy feelings. Perhaps human wisdom is not yet sufficiently reduced in subjection to the simplicity that is in Christ, to make thee as yet willing to stoop to the foolishness of the cross sometimes appearing in the Quaker. I do not mean an irrational or unchristian foolishness but what appeareth foolishness to Sophistry. I suggest these things respecting thyself. I do not say they are so. Forgive my great freedom and burn this if I do not conclude to save thee the trouble. If it goes let the veil of charity cover its defects. And may thou persevere this time in that which shall induce us to address thee in the character of - John Dickinson the worthy - not J. D. Esq., or the Great. Thou will say I suppose I am a strange girl to write as I do. Farewell however.

"Thy friend,

"A. EMILEN, JR."

Again James Bringhurst in 1799 writes to a correspondent a letter which gives certain interesting facts concerning his later life.

"A great change has taken place in John Dickinson although not yet in Membership with $F^{\text {rds }}$, it plainly shews what the powerful operation of Divine Grace las done for him, who was once in almost the highest applause \& popularity of Mankind as to worldly things, having been a great Lawyer, a Politician, a Governor of Pensilvania, \& any station he seemed to chuse - having been the Author of what's called the Farmer's letters some years past, \& now I believe him to be the improving Christian. He has so far 


\section{POLITICAL LEADERS OF PENNSYLVANIA}

taken up the cross as to use the plain language to all, \& is a diligent attender of our religious meetings. I had been intimately acquainted with him \& therefore took the liberty to lay before him in a letter I wrote a few weeks past, the use $\&$ benefit his influence might probably have if he could feel it right to exert it with $G$. Washington, \& some others in high stations on behalf of the poor Black people detained in Bondage. - of his own Negroes he set a number free, in which I was informed he gave up to the amount of between eight \& ten thousand pounds. Respecting that \& some other matters he gave me some account last spring about a week before I left home to come here. - I went to Willmington to see a Son of mine, who is settled there, when J. Dickinson was very pressing with me to spend some time with him at his house, which is large \& comodious \& pleasently situated in that Town, where he lives as a private Gentleman. He possesses vast property \& therefore it is in his power to do much good with it wherein I believe he is good to the poor. I staid longer than I had intended on purpose from his solicitation \& spent part of two days with him, when he was very free \& open in conversation, one part of which I may have room to mention - in speaking of the difference between his former \& present manner of Life, he told me his daughter had been his instructor; he has two children who are daughters lately grown up, no Son. He said, when he lived in Philadelphia, he wished his eldest to learn dancing $\&$ proposed it to her, offering to have a master come to teach her, - at which she made some hesitation. He then desired her to go into her chamber \& set an hour or two alone to consider of it $\&$ then give him an answer. She went as he bid her \& when she returned to him again, her answer was, 'if Father pleases I had much rather be a Friend ' which altho' somewhat mortifying to him at that time he gave up to. That with some other parts of her conduct put him upon closer thinking of the cause. She is a fine young woman of superior understanding, just growing up into the prime of life with every opportunity of indulgence that's apt to be pleasing to young minds. Thus to deny herself of those things, so powerfully struck his mind as gradually with other feelings he experienced to effect a change in him who was in grcat exaltation as to 
worldly Eminence. - I thought this short acc might be agreeable to you both to see, far short it is, to what I could have wrote respecting the conversation we had, but I thought this enough to insert in this letter. I wish this part of it not to be much seen by others, as I should not like any of it as wrote by me, should come to his knowledge that respecting his negroes he told me if some who held such knew of, perhaps it might be an encouragement to them to set theirs free, tho' I dont wish that to be mention'd either from me, - he said he became uneasy in his mind about his, \& therefore thought to accommodate the matter to himself $\&$ them also, \& therefore order'd a number of huts to be built for their better living on the Plantations, \& several other ways endeavor'd to render a state of slavery easy to them, but after all this he found his mind disturbed on their acc $^{\mathrm{t}}$, \& at last deternin'd to set them at liberty, \& wrote a manumission for the whole of them, immediately after which he told me he had a peaceful easy mind, \& everything seemed to prosper in his hands, \& to crown all, his Ineome was abundantly increased contrary to his expectation."

Dated Tiverton Rhode Iland $8^{\text {th }}$ of $10^{\text {th }}$ mo 1799.

He never accepted the historic position of Friends on the subject of the unchristian character of the methods of warfare. Writing to his cousin, George Logan, a grandson of James Logan, then United States Senator from Pennsylvania, he says in 1804 "As standing armies are justly abhorred among us our liberty must depend upon our being an armed nation; and considering the honor of those with whom we have to contend, we must be a populous nation."

Warner Mifflin who was a fellow member of the Convention which framed a Constitution for Delaware in 1782, a Friend in good standing, thus writes of Dickinson's efforts to defeat the causes which Friends had much at heart. "I believe I attended them (the sittings of the Convention) every diay except one meeting-day and am very strongly suspicious that John Dickinson knew that was our meetingday, as he then moved that the blacks should be prevented 


\section{POLITICAL LEADERS OF PENNSYLVANIA}

by the Constitution from purchasing real property \&c. His conduct respecting the blacks and the conscientiously scrupulous against arms, induced one to believe that he was as great an enemy to the cause of righteousness as was in that body. . . . I told him that those who came nearest the truth and were not in it were its greatest enemies."

Thus he lived through his life on the fringe of the Society, identified with them in popular estimation but never fully trusted by their standard members.

Whether Quaker or not he was a devout and pious Christian. His private letters breathe a spirit of fervent religious life, and his kindly but unostentatious donations all through his life betray the sense of responsibility for the proper use of his large wealth. His wife had inherited Fair Hill and when in Philadelphia they spent their life there in a generous hospitality. But knowing that Isaac Norris had desired that the property should descend to the male members of the Norris family, he transferred without compensation all rights in the very valuable estate to the sons of Charles Norris.

The residence at Fair Hill was burned by the British during their occupancy of the city in 1777, part of the Library being saved.

The books left, some 1500 volumes, were given in 1783 to Dickinson College then just established by the Presbyterians. He also donated two tracts of valuable land altogether 500 acres to the new institution. It was chartered "Dickinson College in memory of the great and important services rendered to his country by his Excellency, John Dickinson, Esquire, President of the Supreme Executive Council and in commemoration of his very liberal donation to the institution." He also subscribed to the funds of Princeton College.

Education, charity, religion, these were the purposes to 
which his peaceful later years were devoted. Almost his last words were "I wish happiness to all mankind and the blessings of peace to all the nations of the earth, and these are the constant subjects of my prayers." 



\section{INDEX}

Ascetieism, 13

Ashbridge, George, 145

Assembly, 144

Baneroft, George, 54

Barclay, Robert, 63, 67

Benezet, Anthony, 10

Biddle, John, 44

Biddle, William, 43

Biles, William, 96, 123

Blackwell, Governor, 21, 73

Brissot de Warville, 210

Carpenter, Samuel, 33, 52, 71, 77, $108,122,139,184,201$

Chroniele of ben Saddi, 194

Conscience, Quaker, 15, 51

Davies, Richard, 55

Dickinson, James, 67

Dickinson, John

ancestry, 224

education, 225

studies law, 225

enters public life, 226

contest Franklin and Galloway, 226

Farmer's Letters, 229

infuence in Philadelphia. 230

Continental Congress, 232

represents Friends, 232

moderation, 232

joins army, 234

Governor of Delaware and Pennsylvania, 234

constitutional convention, 234

sympathizes with Republicans, 235 death, 235

as a Friend, 236, 238

marriage, 236

Jetters of A. Fnlen and James Bringhurst, 239

donations, 242

Dixon, Hepworth, 20
Eckley, John, 73, 77

Evans, Governor, 21, 97, 121

Fisher, Daniel, 37

Fleteher, Governor, 78, 88, 89

Ford, Patrick, 22, 26, 97

Fox, Creorge, 63

Franklin, Benjamin, 150, 192, 196, $198,207,215,226$

Freame, Margaret Penn, 42

Friends, society of

alstain from polities, 3

general meeting, 31

war problems, $7,8,50,147$

control Assembly, 145

leave Assembly, 193, 195, 217

Galloway, Joseph, 226, 22S

Goodson, John, 41

Gookin, Governor, 21, 93, 97, 129, 136

Gordon, Governor, 106, 144

Growdon, Joseph, 108

Hanilton, Andrew, 42, 160, 190

Hill, Rieh.'rd, 124, 128, 133, 139, 154 . 184

Hodgkin, Thomas, 18

Holme, Thomas, 59

Ifoskins, Jane, 109

Indian $p$ licy, 47, 48, 49, 140, 174 $185,191,205$

Jenings, Samud, 66

Jolnu a John, 55

Jones, (iriffith, 26

Keith, George, 62, 68

Keith, Sir Witliam, 46, 103, 142, 157

Kinsey, . Iohn ancestry, 156

hat in court, 157 
Kinsey, John - continued

came to Philadelphia, 159

meeting work, 159

state offices, 160

contest with Governor Thomas, $162-169$

chicf justice, 171

Maryland boundary line, 172

bills of credit, 172

differs with governor, 173

treaties with Indians, 174

Allany treaty, 176

death, 176

notices, 177

end of Quaker eontrol, $17 \mathrm{~S}$

meeting notice, 180

Lloyd, Charles, 57

Lloyd, Divid

opposed to Penn, 26

early life, s4

offices in state, 85

differs with Pastorius, 86

politician, 88

opposes Logan, 89, 98, 100

opposes Penn, 90

war grants, 91

identity of Friends with government, 91

Lloyd defeated, $1710,92,102,132$; 1705,96

adjourmment of House, 92

address to Penn, 1704, 94, 122

courts to be established, 99

differs with Gookin, 99, 101

moves to (Chester, 102

sides with ,ir W. Keith, 104

death, 106

ats at lawyer, 106

as a prilitician, 107

as a Friend, $10 \mathrm{~s}$

Jane Fenn, 110

scrvices to state, 111

hiterary work, 113

country people for Lloyd, 131

Lloyd, Grace, 109

Lloyd, 'Thomes

qualities of, '2:2

simns I'enn's rertificate, 33

comes to Pemsylvinia, 60

of proks George Keith, 61
Pastorius and Lloyd, 70

deputy governor, 73

differs with Governor Blackwell, 74,77

deith, 78

cliaricter, 79

memorial of Welsh Friends, 80

letter to Welsh Friends, 82

Logan, Dr. George, 153, 241

Logan, James

comes to Pennsylvania, 89, 115

attitude to war, $91,115,148$

fidelity to Penn, 97

deseent, 114

offices held, 115

dispute with Daniel Cooper, 116

with Thomas Story, 117

relation to Friends, 118

quit-rents and collections, 119

Indian question, 120, 140, 150

polities, 121

bitterness with Lloyd, 122

Evans hoax, 123

powder money, 124

impeached, 125

bad assemblies, 126

Lewes plundered, 127

trustee under Penn's mortgage, 128

goes to England, 129

election of 1710,132

returns, 133

salary, 135

marriage, 138

hetter times, 139

differs with Governor Keith, 143

made chief justice, 146

president of council, 146

aids lotteries, 149

Stenton, 149

influence, 150

intelfectual interests, 151

library, 152

death, 153

descendants, 153

Logan, William, 153

Lotteries, 44

Lower, Thomas, 26

Makin, Thomas, 71

Markham, William, 77, s9, 121

Mather, Cotton, 64 
Mead, William, 26

Mifflin, Warner, 242

Negro meetings, 33

Norris, Deborah, 154

Norris, Isaae, Sr. juilgment of Penn, 25

of Thomas Story, 117

care of young Penn, 122

poor prospeets of Pa., 127

arranges Penn's debts, 128, 184

early life, 181

builds Fairhill, 182

marries Mary Lloyd, 183

polities, 185

Norris, Isaac, 2nd

birth, 186

City Council, 186

merchant, 187

assists Kinsey, 187

goes to Albany, 189

speaker, 189

state house built, 190

liberty bell, 190

Albany treaty, 191

declines to leave Assembly, 194

the Chronicle of Nathan ben Saddi, 194

appointed agent in England, 196

contest with proprietors, 197

death, $19 \mathrm{~s}$

relation to meeting, 198

married life, 199

scholarship, 199

Oaths, 45, 103, 137

Owen, Griffith, 33

\section{Palatines, 144}

Pastorius, F. D., 67, 69, 70, 72, 86

Pemberton, Israel, Sr., 201

Pemberton, Israel, Jr.

leader of Quakers, 202

trouble with Governor Thomas, 202

Inlian interests, 205

Kiner Wampum, 206

Paxton boys, 207

opposes Thomas Penn, 208

tea ship, 209

British smpathizers, 210

Friends in revolution, 210 contest with John Adams, 212

banished to Virginia, 213

death, 213

Pemberton, James

education, 214

offices in church, 214

member of Assembly, 215

character of Assembly, 215

break-up of Quaker majority, 217

Pennsylvania Hospital, 218

Acadians, 219

banished to Virginia, 219

West town School, 220

anti-slavery work, 222

death, 223

Pemberton, Phineas, 71, 200

Penal code, 46, 103

Penn, Hannah C., 103, 105, 135

Penn, John, 147

Penil, Thomas, 147, 196

Penn, William

religious liberty, 10, 36, 93

weak qualities, 23

strong qualities, 24, 27

Isaac Norris' judgment, 25

personality, 29, 30, 33

certificates of English Friends, 32

constitutions, 34,35

democracy, 39

amusements, 43

oaths, 45,103

eapital punishment, 46

Indian poliey, 47, 48, 49

war. $5 t, 52$

diet of nations, 51

travels in Germany, 63

Penn and Pastorius, 70

Penn and Blackwell, 77

financial troubles, 94,97

engages Logan, 115

lind ownership, 120

opposition to Penn, 130

Penn's letter to Friends, 133

sale to crown, 135

paralyzed, 135

Penn, William, Jr., 121

Personality, 9

Punishment, eapital, 46, 138

Quaker roforms, 7

(Quit-rents, 119 
248

Riot of $1742,169,187$

Roberts, Hugh, 41, 69

Roosevelt, Theodore, 160

Second coming, 11

Smith, John, 154, 177

Standards of conduct, 1

Stockdale, Willian, 65

Story, Thomas, 33

\section{INDEX}

Thomas, Governor, 147, 161

Thompson, Charles, 42, 231

War troubles, 101, 162, 170, 19:

Weiser, Conrad, 173, 175

Welsh Friends, 55, 80

Welsh Tract, 59, 74-76

Whitehead, George, 26

Williams, Roger, 10, 36 
THE following pages contain advertisements of a few of the Macmillan books on kindred subjects 



\title{
The Pilgrims and Their History
}

\author{
By Roland G. USHer, Ph.D.
}

Professor of History, Washington University, St. Louis. Author of "Pan-Germanism," "The Reconstruction of the English Church," "The Story of the Pilgrims for Children," Etc.

Illustrated, $12^{\circ}, \$ 2.00$

The approaching tercentenary of the landing of the Pilgrims makes peculiarly timely Professor Usher's new and critical study of The Pilgrims and Their History. While best known to the general reader as the author of Pan-Germanism, he has been known to scholars as the author of authoritative monographs on Stuart History, and particularly the history of the Puritans in England. His account of the Pilgrims is, strange to say, literally the first attempt since the era of modern critical scholarship to treat the whole of Pilgrim History from the point of view of the general reader in a single volume of moderate compass. He has summarized, verified, and qualified the more detailed researches of the last generation of scholars, and has drawn together their results in a narrative which is history without being dull, and is detailed without being pedantic. He has put into three hundred pages all the really pertinent information about the Pilgrims and their history.

"This is a fresh, highly interesting and exceedingly valuable study of the Pilgrims, of their influence on the character of America, and of the historical basis for certain conceptions that have been accepted perhaps too readily. . . With remarkable conciseness and the utmost clarity Professor Usher deals with the questions of significance in connection with the political, economic, and religious aspects of the colony and the tendencies that finally brought Plymouth and the Bay colony together into one commonwealth. Few writers have approached this subject with such obvious freedom from prejudice." - The Continent.

THE MACMILLAN COMPANY

Publishers 64-66 Fifth Avenue Now York 


\section{The Story of the Pilgrims for Children By ROLAND G. USHER}

Illustrated, $\$ 1.25$

The majority of books for children on early American history either tell the traditional story of the Pilgrims, long ago rejected by all critical students, or create imaginary incidents and characters which subordinate the great Pilgrims and thrust them into the background of the child's mind.

There has long been a demand for a story of the Pilgrims for children which should make Bradford, Brewster, Winslow, and Standish themselves the heroes, which should be accurate in fact, which should not resort to imaginary characters and incidents in an attempt to vivify the narrative. It should be dramatic and patriotic, a story which should leave in the child's mind correct impressions about the fundamental factors in Pilgrim History as well as narrate the details of the voyage and the landing. Professor Usher has, therefore, retold for children the same story he has so carefully substantiated with contemporary evidence in The Pilgrims and Their History.

The numerous illustrations are authoritative and have a direct relation to the main facts of the narrative.

\section{THE MACMILLAN COMPANY} Publishers 


\title{
The Quakers in the American Colonies
}

\author{
By Prof. RUFUS M. JONES, M.A., D.Lirt.
}

\author{
ASSISTED BY \\ ISAAC SHARPLESS, D.Sc. \\ AND \\ AMELIA M. GUMMERE
}

$8 v 0, \$ 3.00$

This volume is a historical and critical study of the Quaker religious movement; a movement important both for the history of the development of religion and for the history of the American Colonies. The subject is presented not only in its external setting but also in the light of its inner meaning. The story of the Quaker invasion of the Colonies in the New World has often been told in fragmentary fashion, but no adequate study of the entire Quaker movement in Colonial times has yet been made from original sources, free from partisan or sectarian prejudice and with due historical perspective. The accounts written from the Quaker point of view do not furnish a critical investigation of Quakerism and its work in the New World; while those written from the anti-Quaker point of view are for the most part one-sided and colored by prejudice, and are obviously lacking in penctration into the inner meaning of the type of religion which they undertake to present. By avoiding these extremes and by furnishing a critical investigation of Quakerism both in its outer forms and its inner spirit. Professor Jones has produced an excellent piece of work, done in an impartial and historical spirit and not too brief to admit of details. The account is an able and clear treatment of the religious principles of Quakerism, replete with first-hand knowledge and with concrete details, and thus it presents a truly historical picture of this great movement which bore no small part in the early political and religious life of this country.

This volume is divided into five books. Book I. deals with the Quakcrs in New England; Book II. with Quakerism in the Colony of New York: Book III. with the Quakers in the Southern Colonies; Book IV. deals with the early Quakers in New Jersey, and Book V. with the Quakers in Pennsylvania.

The work thus admirably assists the man of to-day to visualize the life history of the Quaker movement on this continent.

\section{THE MACMILLAN COMPANY \\ Publishers 64-66 Fifh Avenue lTew York}




\title{
William Penn
}

\author{
BY RUPERT S. HOLLAND
}

Illustrated, $12^{\circ}, \$ .50$

The life of William Penn is of especial interest and value because the events of his career are closely related to American and English history at a time when America was separating herself from her parent country and shaping her destiny as an independent Republic. Mr. Holland presents the great American as a man of noble character and a fearless champion of liberty.

"This story of Penn includes more than a mere narrative of the chief events of his life. It presents a good deal of material on the ideas and the customs of the Quakers both in England and in Pennsylvania, and it gives an excellent delineation of Penn's character. Penn's steadfast adherence to the Quaker cause in spite of his father's efforts to coerce and persuade him to abandon it; his cheerfulness under adversity, even imprisonment; his ardent nature; his ability as a debater; his success as a land boomer in interesting people in his colonial projects; his friendly relations with the Indians; his readiness to defend himself physically whenever occasion demanded it; and the odd admixture of the courtier and the Quaker in his manner and conduct, are made to stand out very prominently. Enough of incident is incorporated to insure the retention of interest on the part of the young reader. The illustrations are authentic

- "The book should have a wide circulation among the boys and girls of the high schools. No doubt many adults will find it delightful rapid reading." - Mississippi Valley Historical Review.

\section{THE MACMILLAN COMPANY Publishers \\ 64-66 Fifth Avenue \\ Now York}







\section{HECKMAN \\ BINDERY INC.}

DEC 89

U⿴囗十⺝ N. MANCHESTER, 
